DOE/OR/01-2154\&D2/A1

\title{
Addendum to the East Tennessee Technology Park Site-Wide Residual Contamination Remedial Investigation Work Plan Oak Ridge, Tennessee
}

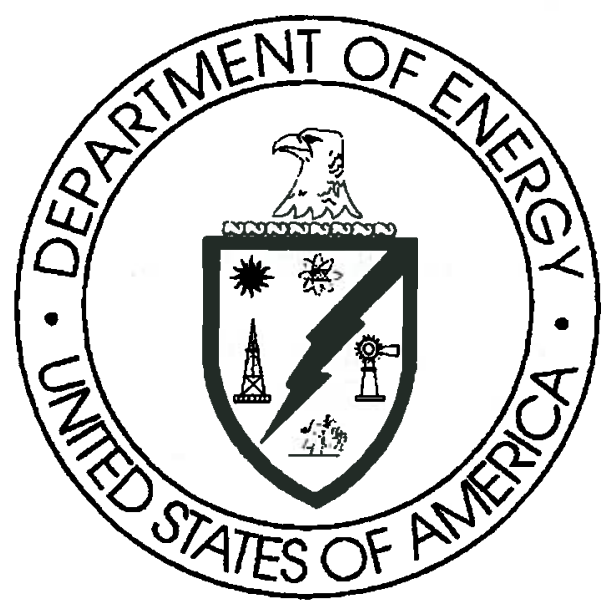

This document is approved for public release per review by:

P.J. Kortman

BJC ETTP Classification and Information Control Office
$4 / 19 / 2011$

Date 


\section{SCIENCE APPLICATIONS INTERNATIONAL CORPORATION}

contributed to the preparation of this document and should not be considered an eligible contractor for its review. 


\title{
Addendum to the East Tennessee Technology Park Site-Wide Residual Contamination Remedial Investigation Work Plan Oak Ridge, Tennessee
}

Date Issued-April 2011

\author{
Prepared by \\ Science Applications International Corporation \\ Oak Ridge, Tennessee \\ under subcontract 23900-BA-PR007U \\ under work release 0012 \\ Prepared for the \\ U. S. Department of Energy \\ Office of Environmental Management

\section{BECHTEL JACOBS COMPANY LLC} \\ managing the \\ Environmental Management Activities at the \\ East Tennessee Technology Park \\ Y-12 National Security Complex Oak Ridge National Laboratory \\ Paducah Gaseous Diffusion Plant Portsmouth Gaseous Diffusion Plant \\ under contract DE-AC05-98OR22700 and DE-AC05-03OR22980 \\ for the \\ U. S. DEPARTMENT OF ENERGY
}




\section{CONTENTS}

FIGURES

FIGURES

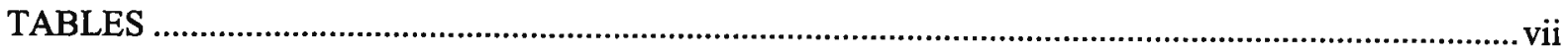

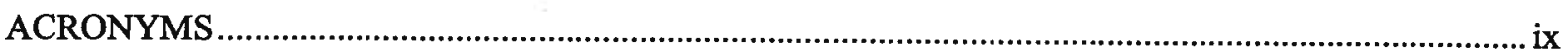

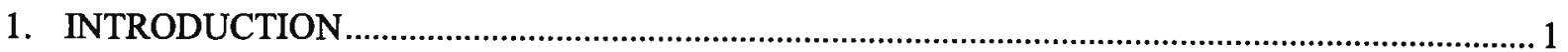

2. PROJECT ORGANIZATION AND RESPONSIBILITIES ............................................................. 1

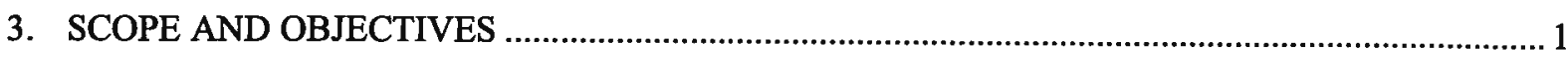

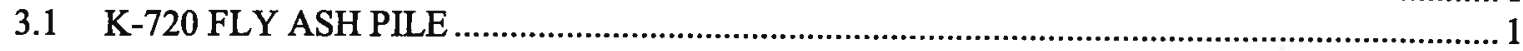

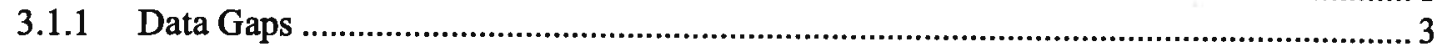

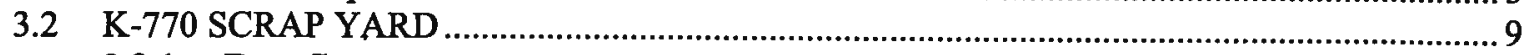

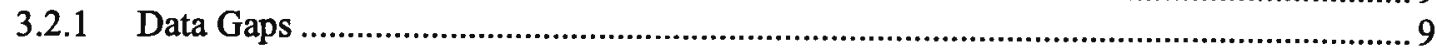

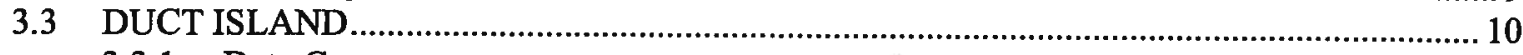

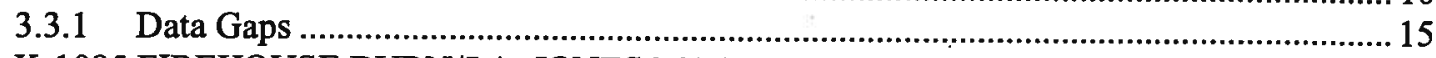

3.4 K-1085 FIREHOUSE BURN/J.A. JONES MAINTENANCE AREA ……………………....... 15

3.4.1 Data Gaps ................................................................................................... 18

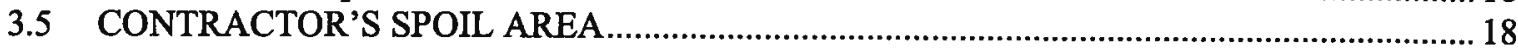

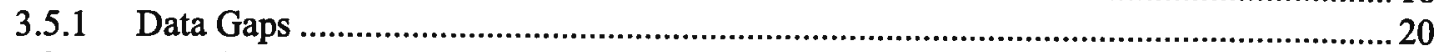

3.6 FORMER K-1070-A BURIAL GROUND ………………………………………....2 21

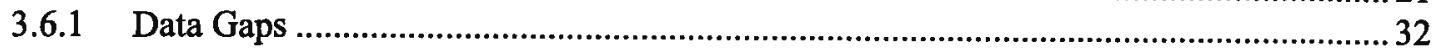

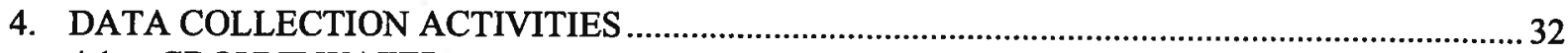

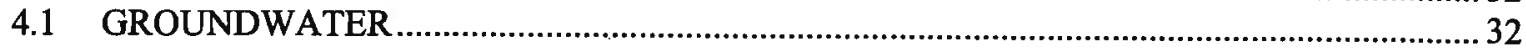

4.1.1 K-720 Fly Ash Pile .............................................................................................. 32

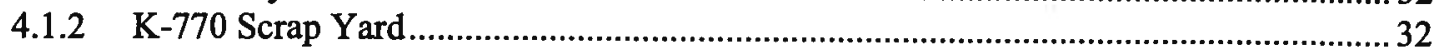

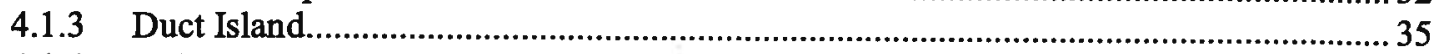

4.1.4 K-1085 Firehouse Burn/J.A. Jones Maintenance Area................................................... 35

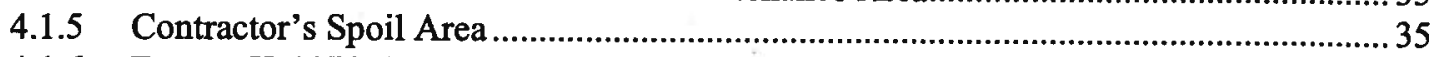

4.1.6 Former K-1070-A Burial Ground...……………………………………………35

4.1.7 Groundwater Sample Collection Method ................................................................... 41

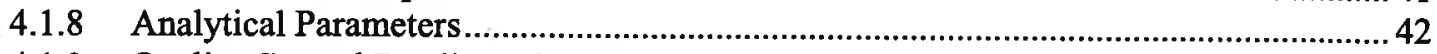

4.1.9 Quality Control Duplicate Samples ………………………………………………....42

4.1.10 Monitoring Well Drilling and Installation................................................................ 42

4.2 SURFACE WATER AND SEDIMENT SAMPLING ………………………………….... 47

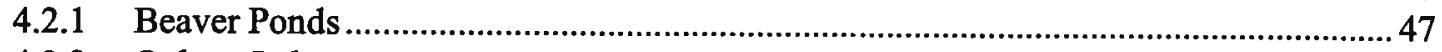

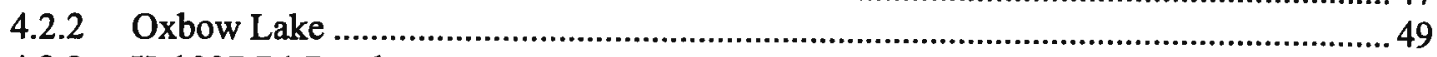

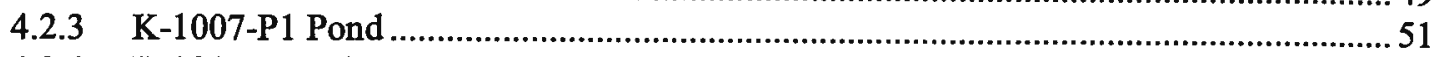

4.2.4 K-901-A Pond ……………………………………………………………. 51

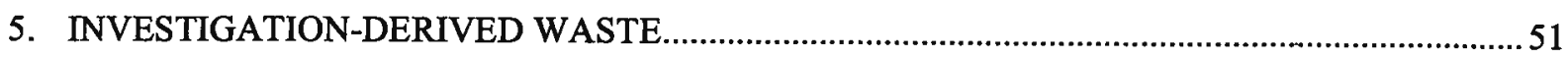

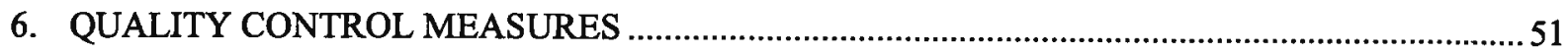




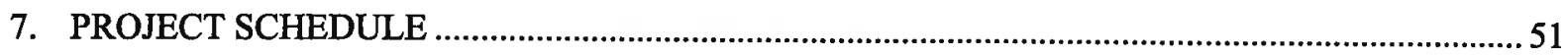

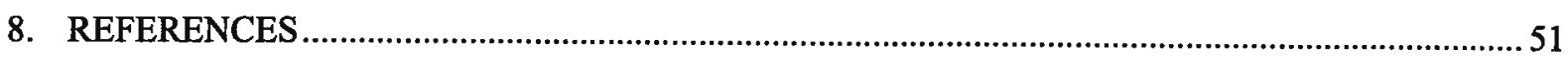

APPENDIX A QUALITY ASSURANCE PROJECT PLAN ...........................................................A-1 


\section{FIGURES}

$1 \quad$ K-720 Fly Ash and K-770 Scrap Yard monitoring well locations. .................................................. 2

2 Geologic cross-section A-A', K-720 Fly Ash Pile area. .................................................................. 5

3 Geologic cross-section B-B', K-720 Fly Ash Pile area........................................................... 6

$4 \quad$ Radioactivity in groundwater in the K-770 Scrap Yard area. ................................................... 10

5 Maximum concentrations of VOCs exceeding MCLs in the Duct Island subwatershed. ................. 11

6 VOC concentrations at the PCO Spring............................................................................ 15

7 Maximum concentrations of selected VOCs, K-1085 Firehouse Burn and J. A. Jones Area. .......... 16

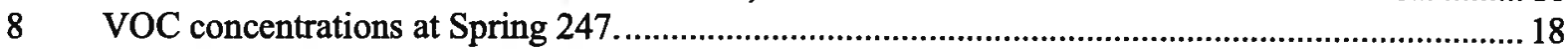

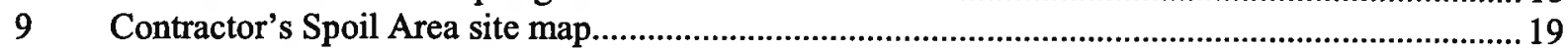

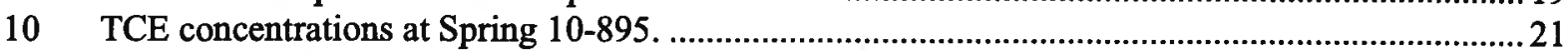

11 Trichloroethene in unconsolidated groundwater in the K-901/K-1070-A Area, Feb./March

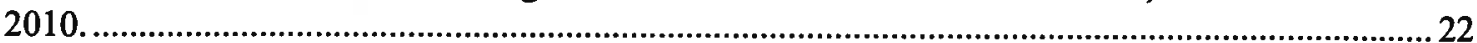

12 Trichloroethene in bedrock groundwater in the K-901/K-1070-A Area, Feb./March 2010............23

13 Observed concentration trends in K-1070-A well UNW-121 .................................................2 25

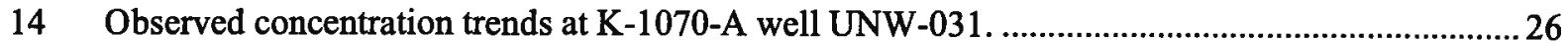

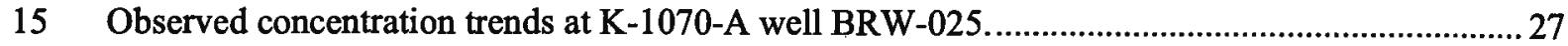

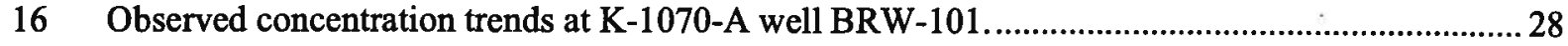

17 Observed concentration trends at K-1070-A well BRW-103...................................................29

18 Cross-section location in groundwater in the K-1070-A/K-901 Area at ETTP. ........................... 30

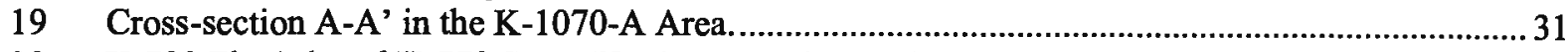

20 K-720 Fly Ash and K-770 Scrap Yard proposed sampling locations............................................ 34

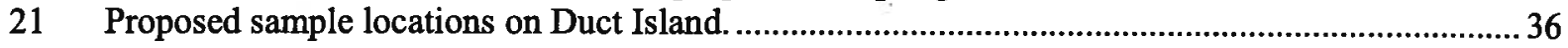

22 Proposed sampling locations at the K-1085 Old Firehouse Burn/J. A. Jones Maintenance

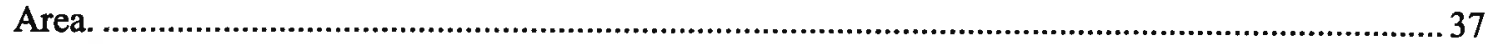

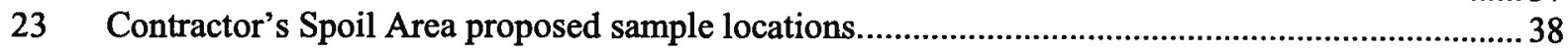

24 Proposed well locations at the former K-1070-A Burial Ground................................................ 39

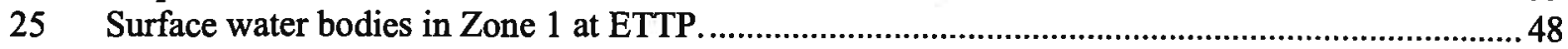

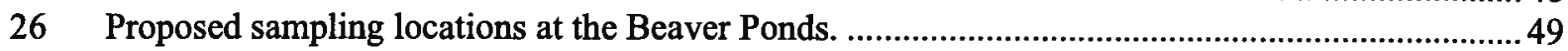

27 Proposed sampling locations at the Oxbow Lake....................................................................5 50 



\section{TABLES}

1 Observed maximum soil concentrations at the K-720 Fly Ash Pile area ...................................... 7

2 Observed groundwater concentrations from the monitoring well within the Fly Ash Pile

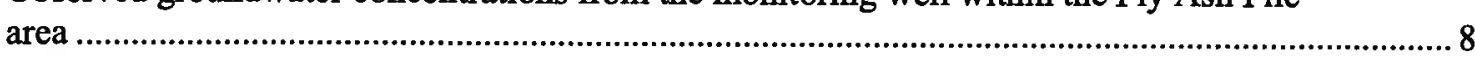

3 Selected VOCs detected in the PCO Spring on Duct Island ................................................... 13

4 Selected constituents detected in groundwater wells at the K-1070-F Construction Spoil

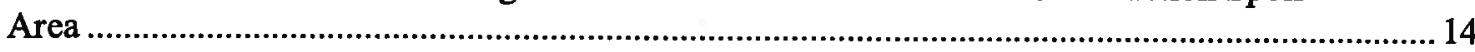

5 Summary of the proposed sampling approach to address the Zone 1 groundwater data gaps .......... 33

6 Container, preservation, and holding time requirements for Zone 1 samples ..................................40 



\title{
ACRONYMS
}

\author{
ASTM American Society for Testing and Materials \\ AT123D Analytical Transient 1-, 2-, 3-Dimensional (modeling) \\ AWQC ambient water quality criteria \\ bgs below ground surface \\ BORCE Blackoak Ridge Conservation Easement \\ BRW bedrock well \\ CERCLA Comprehensive Environmental Response, Compensation, and Liability Act of 1980 \\ COC contaminant of concern \\ CMCOPC contaminant migration contaminant of potential concern \\ CSA Contractor's Spoil Area \\ CSM conceptual site model \\ DCE dichloroethene \\ DOE U. S. Department of Energy \\ DVS Dynamic Verification Strategy \\ EPA U. S. Environmental Protection Agency \\ ETTP East Tennessee Technology Park \\ EU exposure unit \\ EWQP ETTP Water Quality Program \\ FFA Federal Facility Agreement \\ FS feasibility study \\ MCL maximum contaminant level \\ $\mathrm{mg} / \mathrm{L} \quad$ milligrams per liter \\ MNA monitored natural attenuation \\ NFA no further action \\ ORR Oak Ridge Reservation \\ PAH polycyclic aromatic hydrocarbon \\ PCB polychlorinated biphenyl \\ PCCR Phased Construction Completion Report \\ $\mathrm{pCi} / \mathrm{g} \quad$ picocuries per gram \\ $\mathrm{pCi} / \mathrm{L} \quad$ picocuries per liter \\ PCE tetrachloroethene \\ PRG preliminary remediation goal \\ PVC polyvinyl chloride \\ QAPP Quality Assurance Project Plan \\ QC quality control \\ RI remedial investigation \\ RL remediation level \\ ROD Record of Decision \\ RSL regional screening level \\ SESOIL Seasonal Soil (compartment) modeling \\ SU soil unit \\ SVOC semivolatile organic compound \\ TCE trichloroethene \\ TcRmA time-critical removal action \\ TDEC Tennessee Department of Environment and Conservation \\ TDOT Tennessee Department of Transportation \\ TFCF Toroidal Fusion Core Facility
}


UNW

UST

VOC

unconsolidated zone wcll underground storage tank volatile organic compound 


\section{INTRODUCTION}

The East Tennessee Technology Park Site-Wide Residual Contamination Remedial Investigation Work Plan (DOE 2004) describes the planned fieldwork to support the remedial investigation (RI) for residual contamination at the East Tennessee Technology Park (ETTP) not addressed in previous Comprehensive Environmental Response, Compensation, and Liability Act of 1980 (CERCLA) decisions. This Addendum describes activities that will be conducted to gather additional information in Zone 1 of the ETTP for groundwater, surface water, and sediments.

This Addendum has been developed from agreements reached in meetings held on June 23, 2010, August 25, 2010, October 13, 2010, November 13, 2010, December 1, 2010, and January 13, 2011, with representatives of the U. S. Department of Energy (DOE), U. S. Environmental Protection Agency (EPA), and Tennessee Department of Environment and Conservation (TDEC).

\section{PROJECT ORGANIZATION AND RESPONSIBILITIES}

See the East Tennessee Technology Park Site-Wide Residual Contamination Remedial Investigation Work Plan (DOE 2004) for project organization and responsibilities.

\section{SCOPE AND OBJECTIVES}

Based on historical to recent groundwater data for ETTP and the previously completed Sitewide Remedial Investigation for the ETTP (DOE 2007a), the following six areas of concern have been identified that exhibit groundwater contamination downgradient of these areas above state of Tennessee and EPA drinking water maximum contaminant levels (MCLs):

- K-720 Fly Ash Pile,

- K-770 Scrap Yard,

- Duct Island,

- K-1085 Firehouse Burn/J.A. Jones Maintenance Area,

- Contractor's Spoil Area (CSA), and

- Former K-1070-A Burial Ground.

The following discussions present a brief summary of the history of the areas, the general conceptual models for the observed groundwater contamination, and the data gaps identified.

\subsection{K-720 FLY ASH PILE}

The K-720 Fly Ash Pile is located adjacent to the former Coal Pile area and between the K-720 slough and the Clinch River, at the southern edge of the Powerhouse Area (Fig. 1). The Fly Ash Pile operated from 1944 to 1962 (Energy Systems 1995). The fly ash contains bottom ash, slag, and coal fines generated as a by-product of the electric power generation operations located in the K-770 area. Fly ash is known to contain heavy metals. The Fly-Ash Pile has been covered with lime, a soil cover placed over the ash and lime, and the area planted with trees and grass. 


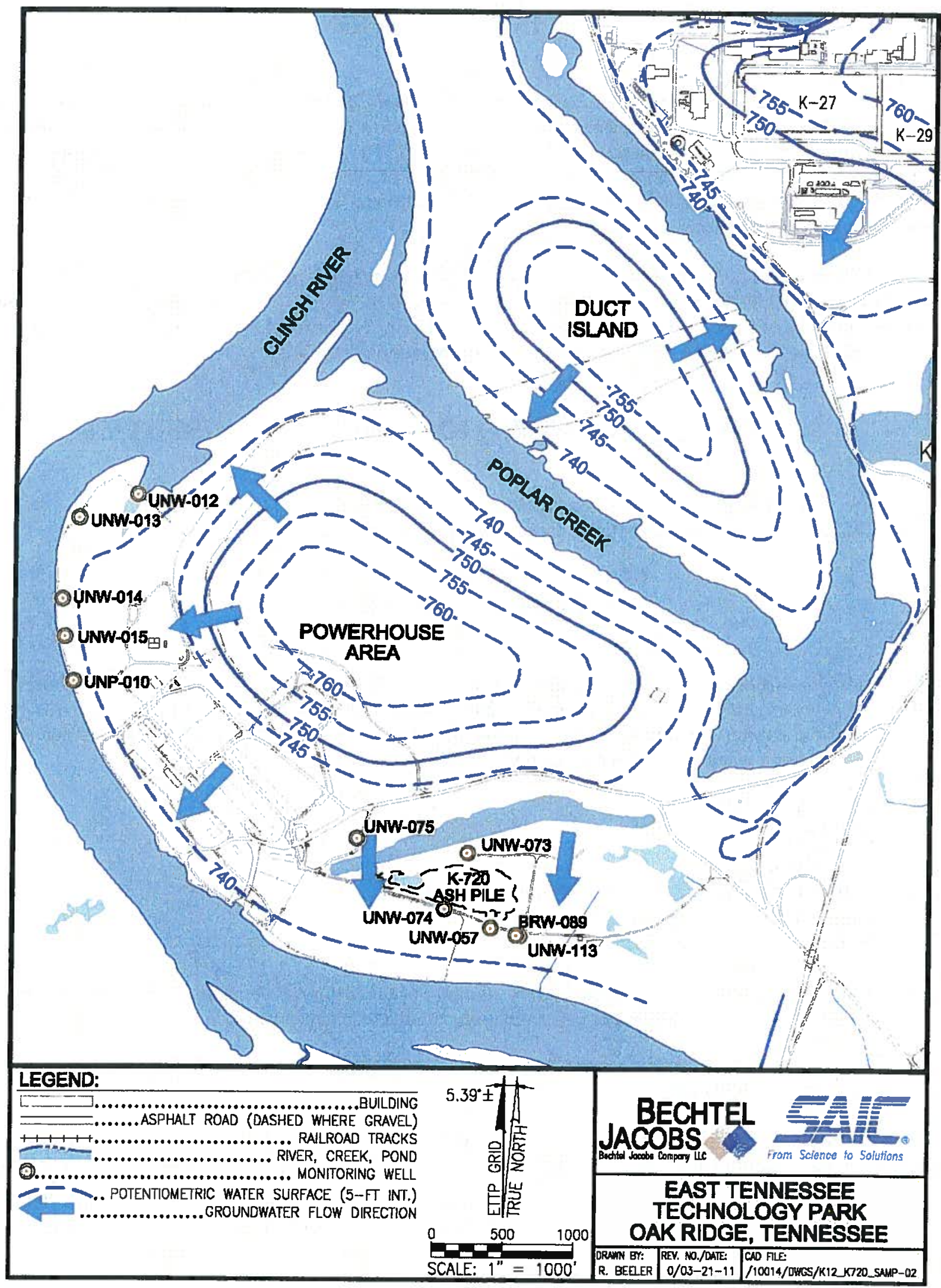

Fig. 1. K-720 Fly Ash and K-770 Scrap Yard monitoring well locations. 
An analysis of the potential transport of metals from soil to groundwater was reported in the Phased Construction Completion Report (PCCR) prepared for the exposure unit (EU) occupied by the fly ash pile (DOE 2010). This analysis included development of mathematical models to estimate the amount of contaminants released from soil, their attenuation during migration through the groundwater, and the concentration that would occur in water downgradient at the receptor location, which in this case is the Clinch River. The results of this evaluation are summarized below.

Shallow groundwater in the area of the K-720 Fly Ash Pile flows generally south and southwest toward the Clinch River, located approximately $330 \mathrm{ft}$ west and downgradient of the fly ash pile. Groundwater flow in the deeper bedrock likely follows solution-enlarged features such as bedding planes and fractures, both along strike and down-dip toward the Clinch River. The horizontal hydraulic gradient is relatively flat in this area. Figures 2 and 3 show geologic cross-sections along with the extent of the metal-contaminated area.

Based on the soil data collected from the area of the ash pile, several metals and organic residues were found in the surface and subsurface soil below and around the K-720 Fly Ash Pile. Based on a soil screening analysis, eight metals and one semivolatile organic compound (SVOC) [see Table 1] were identified as contaminant migration contaminants of potential concern (CMCOPCs) [i.e., exceeding their respective soil screening levels based on leaching to groundwater]. Based on the groundwater sampling results from six monitoring wells in the vicinity of the fly ash pile, cobalt, iron, manganese, and thallium have been observed to exceed their respective MCLs or regional screening levels (RSLs) [Table 2; Figs. 2 and 3]. Thallium had consistently been detected at concentrations exceeding the MCL value of 0.002 milligrams per liter $(\mathrm{mg} / \mathrm{L})$ in all five wells located adjacent to the K-720 Fly Ash Pile area sampled between 1994 and 1998. However, when two of these wells (UNW-057 and UNW-073) were sampled recently (September 2009), thallium was a non-detect in both of these wells. In addition, no other MCLs were exceeded at these two wells. It may be concluded that thallium may have been attenuated by adsorption, surface complexation, and ion-exchange reactions.

The principal mechanism of contaminant transport at the K-720 Fly Ash Pile is infiltration through the fly ash and unsaturated soils that causes contaminants to leach from these materials into the groundwater, or by direct contact of the water table with the contaminated soil mass, thereby leaching contaminants from the soils to groundwater. Low $\mathrm{pH}$ levels in groundwater in this area, produced from reaction with the fly ash and residual coal materials, serve to increase the leachability of metals from the surrounding soil. SESOIL (Seasonal Soil [compartment]) modeling was performed (DOE 2010) to account for contaminant transport mechanism through leaching. Results of this modeling indicated that seven metals (antimony, arsenic, cadmium, lead, mercury, selenium, and thallium) and one SVOC [benzo(a)pyrene] would be leaching to groundwater with concentrations exceeding their respective MCL or EPA RSL. Results from SESOIL modeling were used by a lateral transport model (AT123D Analytical Transient 1-, 2-, 3-Dimensional) to predict contaminant migration through groundwater and the expected future concentrations at the downgradient receptor location (the Clinch River). Results of these analyses indicated that none of these metals that are leaching to the water table would migrate to the Clinch River. The contaminants are expected to naturally attenuate in the groundwater system through chemical immobilization, advection, adsorption, and dispersion.

\subsubsection{Data Gaps}

The primary concern for groundwater in the vicinity of the K-720 Fly Ash Pile is the concentration of several metals that exceeds either TDEC and EPA drinking water standards or EPA RSLs. Elevated concentrations above MCLs or RSLs for the metals cobalt, iron, manganese, and thallium have historically been detected in monitoring wells located downgradient of the fly ash pile. 
THIS PAGE INTENTIONALLY LEFT BLANK.

$11-031(\mathrm{E}) / 041311$ 


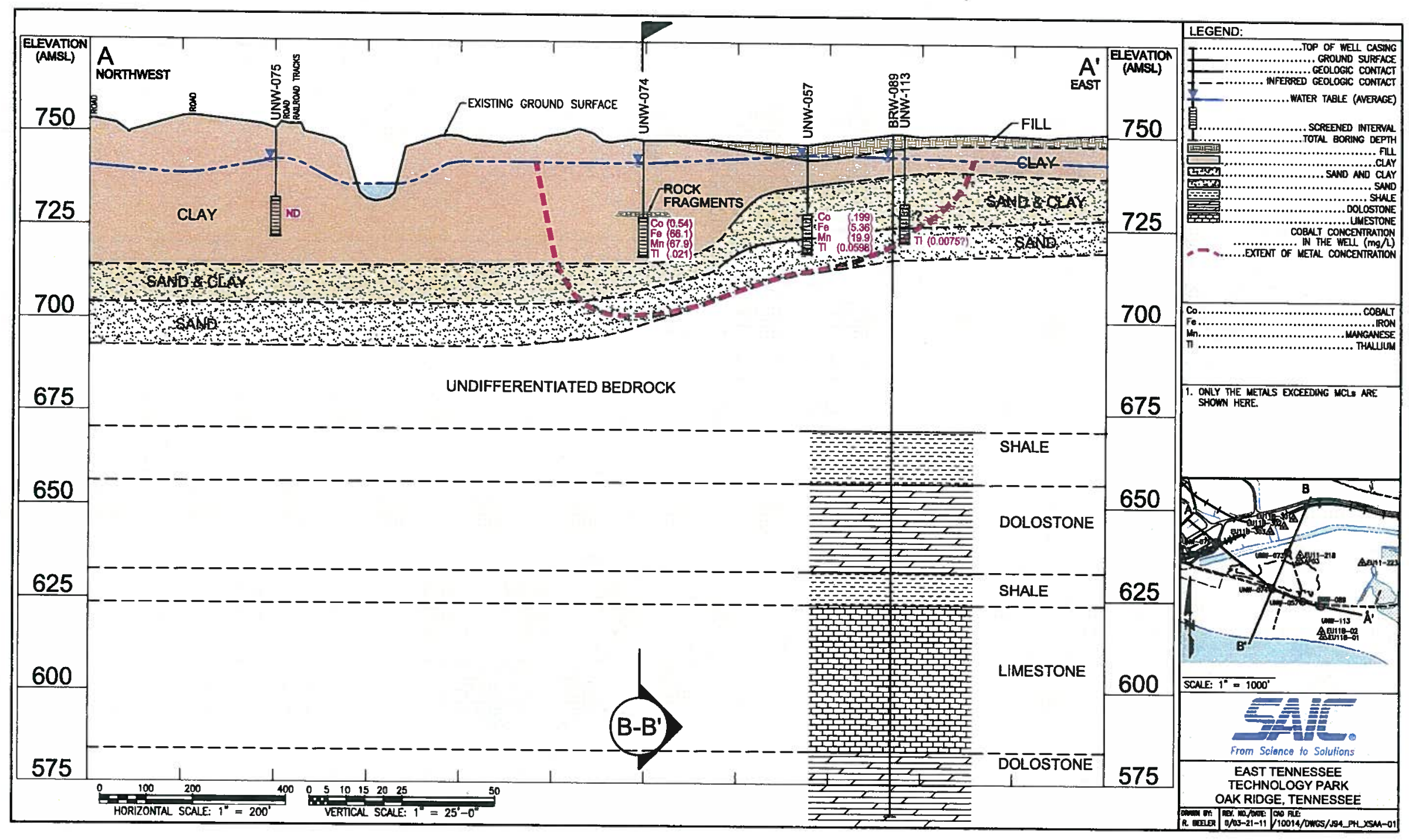

Fig. 2. Geologic cross-section A-A', K-720 Fy Ash Pile area. 


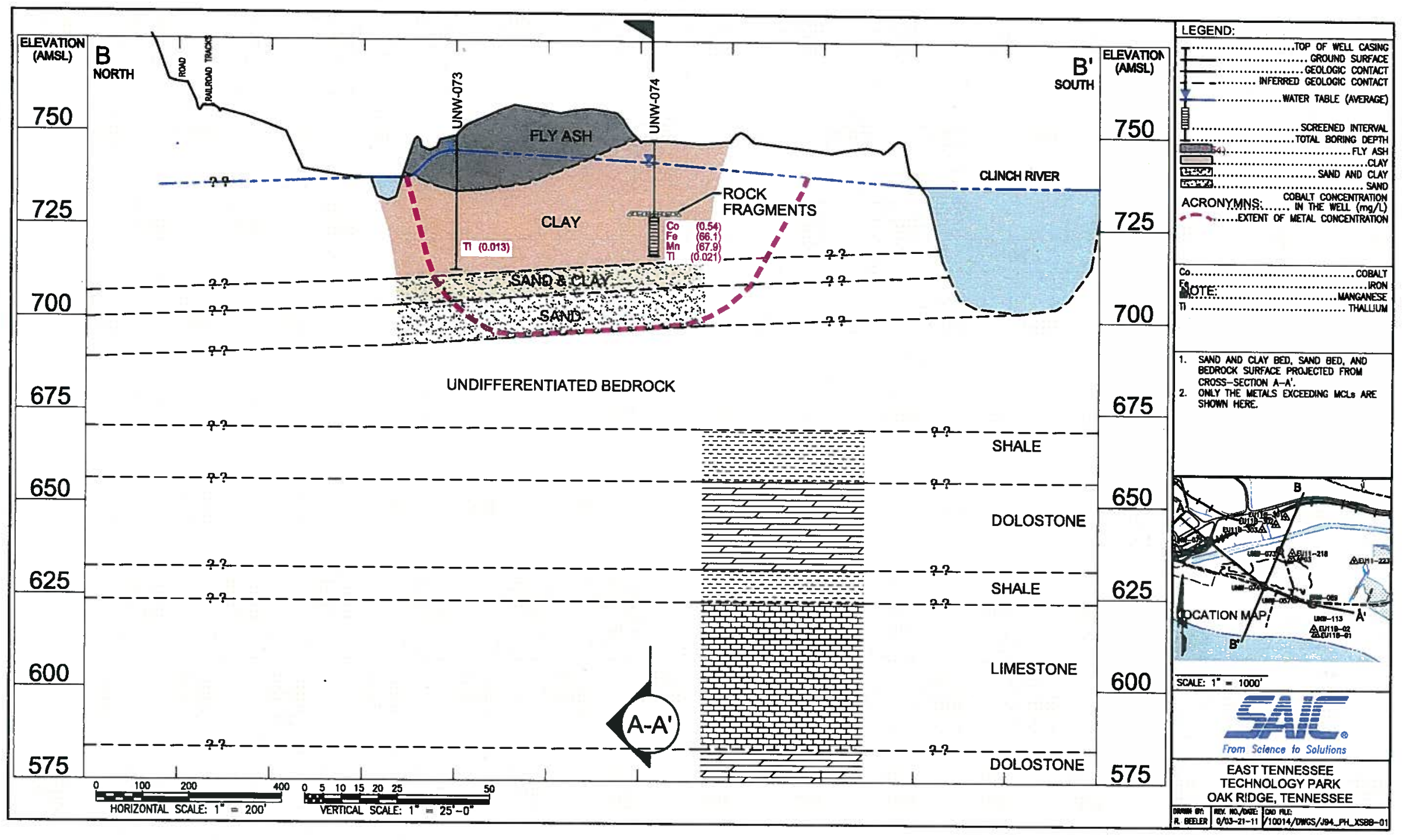


Table 1. Observed maximum soll concentrations at the K-720 Fly Ash Pile area

\begin{tabular}{lcccc}
\hline Constituent & Units & $\begin{array}{c}\text { Maximum } \\
\text { concentration }\end{array}$ & $\begin{array}{c}\text { Sample } \\
\text { location }\end{array}$ & $\begin{array}{c}\text { Sampling } \\
\text { date }\end{array}$ \\
\hline & & Metals & & \\
Antimony & $\mathrm{mg} / \mathrm{kg}$ & $4.1 \mathrm{E}+00$ & EU11B-01 & $5 / 9 / 2005$ \\
Arsenic & $\mathrm{mg} / \mathrm{kg}$ & $8.4 \mathrm{E}+01$ & EU11-204 & $9 / 29 / 2008$ \\
Barium & $\mathrm{mg} / \mathrm{kg}$ & $2.17 \mathrm{E}+02$ & AP03 & $9 / 30 / 1997$ \\
Cadmium & $\mathrm{mg} / \mathrm{kg}$ & $2.5 \mathrm{E}+00$ & EU11-223 & $5 / 10 / 2005$ \\
Chromium & $\mathrm{mg} / \mathrm{kg}$ & $3.38 \mathrm{E}+01$ & AP03 & $9 / 30 / 1997$ \\
Lead & $\mathrm{mg} / \mathrm{kg}$ & $4.6 \mathrm{E}+01$ & EU11-201 & $9 / 25 / 2008$ \\
Mercury & $\mathrm{mg} / \mathrm{kg}$ & $7.8 \mathrm{E}-01$ & AP01 & $9 / 30 / 1997$ \\
Selenium & $\mathrm{mg} / \mathrm{kg}$ & $5.1 \mathrm{E}+00$ & EU11-204 & $9 / 29 / 2008$ \\
Thallium & $\mathrm{mg} / \mathrm{kg}$ & $8.8 \mathrm{E}-01$ & EU11-218 & $5 / 10 / 2008$ \\
& Semivolatile Organics & & \\
Benzo $(a)$ pyrene & $\mathrm{mg} / \mathrm{kg}$ & $2.5 \mathrm{E}+03$ & EU11B-02 & $5 / 9 / 2005$ \\
\hline
\end{tabular}

$\mathrm{EU}=$ exposure unit.

$\mathrm{mg} / \mathrm{kg}=$ milligram per kilogram. 
Table 2. Observed groundwater concentrations from the monitoring well within the Fly Ash Pile area

\begin{tabular}{|c|c|c|c|c|c|c|c|}
\hline Analyte & Location & $\begin{array}{c}\text { Maximum } \\
\text { concentration } \\
(\mathrm{mg} / \mathrm{L})\end{array}$ & $\begin{array}{c}\text { Maximum } \\
\text { concentration } \\
\text { sample date }\end{array}$ & $\begin{array}{c}\text { Latest } \\
\text { concentration } \\
(\mathbf{m g} / \mathbf{L})\end{array}$ & $\begin{array}{c}\text { Last } \\
\text { sample } \\
\text { date }\end{array}$ & $\begin{array}{c}\mathbf{M C L}^{a} \\
(\mathrm{mg} / \mathbf{L})\end{array}$ & $\begin{array}{c}\text { Currently } \\
\text { exceeds } \\
\text { MCL? }\end{array}$ \\
\hline Antimony & UNW-073 & $8.87 \mathrm{E}-02$ & $9 / 29 / 1994$ & ND & $9 / 9 / 2009$ & $6.00 \mathrm{E}-03$ & No \\
\hline Arsenic & UNW-073 & $1.59 \mathrm{E}-01$ & $9 / 29 / 1994$ & ND & 9/9/2009 & $1.00 \mathrm{E}-02$ & No \\
\hline Cadmium & UNW-057 & $1.00 \mathrm{E}-02$ & $2 / 23 / 1990$ & $8.00 \mathrm{E}-04$ & 9/9/2009 & $5.00 \mathrm{E}-03$ & No \\
\hline Cadmium & UNW-073 & $1.20 \mathrm{E}-02$ & $3 / 1 / 1990$ & $5.00 \mathrm{E}-04$ & 9/9/2009 & $5.00 \mathrm{E}-03$ & No \\
\hline Cadmium & UNW-074 & $1.80 \mathrm{E}-02$ & $3 / 1 / 1990$ & $4.70 \mathrm{E}-03$ & $9 / 21 / 1995$ & $5.00 \mathrm{E}-03$ & No \\
\hline Cobalt & UNW-057 & $1.31 \mathrm{E}+00$ & $9 / 28 / 1994$ & $1.99 \mathrm{E}-01$ & $9 / 9 / 2009$ & $1.10 \mathrm{E}-02$ & Yes \\
\hline Cobalt & UNW-074 & $1.21 \mathrm{E}+00$ & $9 / 29 / 1994$ & $5.41 \mathrm{E}-01$ & $9 / 21 / 1995$ & $1.10 \mathrm{E}-02$ & Yes \\
\hline Cobalt & UNW-075 & $1.18 \mathrm{E}-02$ & $9 / 20 / 1995$ & $1.18 \mathrm{E}-02$ & $9 / 20 / 1995$ & $1.10 \mathrm{E}-02$ & Yes \\
\hline Iron & BRW-089 & $3.18 \mathrm{E}+01$ & $8 / 26 / 1998$ & $3.18 \mathrm{E}+01$ & $8 / 26 / 1998$ & $2.60 \mathrm{E}+01$ & Yes \\
\hline Iron & UNW-057 & $4.40 \mathrm{E}+01$ & $6 / 17 / 1989$ & $5.36 \mathrm{E}+00$ & $9 / 9 / 2009$ & $2.60 \mathrm{E}+01$ & Yes \\
\hline Iron & UNW-073 & $6.70 \mathrm{E}+01$ & $9 / 29 / 1994$ & 7.33E-01 & $9 / 9 / 2009$ & $2.60 \mathrm{E}+01$ & No \\
\hline Iron & UNW-074 & $9.84 \mathrm{E}+01$ & 9/29/1994 & $6.61 \mathrm{E}+01$ & $9 / 21 / 1995$ & $2.60 \mathrm{E}+01$ & Yes \\
\hline Lead & UNW-057 & $1.30 \mathrm{E}-01$ & $11 / 1 / 1989$ & ND & $9 / 9 / 2009$ & $1.50 \mathrm{E}-02$ & No \\
\hline Lead & UNW-073 & $5.30 \mathrm{E}-02$ & $4 / 16 / 1990$ & ND & $9 / 9 / 2009$ & $1.50 \mathrm{E}-02$ & No \\
\hline Lead & UNW-074 & $1.50 \mathrm{E}-01$ & $1 / 2 / 1990$ & $8.00 \mathrm{E}-04$ & $9 / 21 / 1995$ & $1.50 \mathrm{E}-02$ & No \\
\hline Manganese & BRW-089 & $4.87 \mathrm{E}+00$ & $5 / 20 / 1998$ & $4.87 \mathrm{E}+00$ & $5 / 20 / 1998$ & $8.80 \mathrm{E}-01$ & Yes \\
\hline Manganese & UNW-057 & $7.87 \mathrm{E}+01$ & $8 / 24 / 1998$ & $1.99 \mathrm{E}+01$ & $9 / 9 / 2009$ & $8.80 \mathrm{E}-01$ & Yes \\
\hline Manganese & UNW-073 & $2.24 \mathrm{E}+00$ & 9/29/1994 & $1.35 \mathrm{E}+00$ & $9 / 9 / 2009$ & $8.80 \mathrm{E}-01$ & Yes \\
\hline Manganese & UNW-074 & $1.19 \mathrm{E}+02$ & 9/29/1994 & $6.79 \mathrm{E}+01$ & 9/21/1995 & $8.80 \mathrm{E}-01$ & Yes \\
\hline Selenium & UNW-057 & 7.39E-02 & $9 / 28 / 1994$ & ND & $9 / 9 / 2009$ & $5.00 \mathrm{E}-02$ & No \\
\hline Selenium & UNW-074 & $7.60 \mathrm{E}-02$ & 9/29/1994 & ND & $9 / 9 / 2009$ & $5.00 \mathrm{E}-02$ & No \\
\hline Thallium & BRW-089 & $4.40 \mathrm{E}-03$ & $5 / 20 / 1998$ & $4.40 \mathrm{E}-03$ & $5 / 20 / 1998$ & $2.00 \mathrm{E}-03$ & Yes \\
\hline Thallium & UNW-057 & $6.23 \mathrm{E}-02$ & $6 / 2 / 1998$ & ND & $9 / 9 / 2009$ & $2.00 \mathrm{E}-03$ & No \\
\hline Thallium & UNW-073 & $1.00 \mathrm{E}-02$ & $1 / 3 / 1990$ & ND & $9 / 9 / 2009$ & $2.00 \mathrm{E}-03$ & No \\
\hline Thallium & UNW-074 & $2.07 \mathrm{E}-02$ & $9 / 21 / 1995$ & $2.07 \mathrm{E}-02$ & $9 / 21 / 1995$ & $2.00 \mathrm{E}-03$ & Yes \\
\hline Thallium & UNW-075 & $2.90 \mathrm{E}-03$ & $3 / 6 / 1995$ & ND & $9 / 20 / 1995$ & $2.00 \mathrm{E}-03$ & No \\
\hline Thallium & UNW-113 & $8.00 \mathrm{E}-03$ & 9/27/1994 & $7.50 \mathrm{E}-03$ & $9 / 21 / 1995$ & $2.00 \mathrm{E}-03$ & Yes \\
\hline
\end{tabular}

${ }^{a}$ Value represents U. S. Environmental Protection Agency (EPA) or state of Tennessee drinking water MCL, or the EPA tapwater regional screening level if MCL does not exist.

${ }^{b}$ Based on most recent sampling event at each well.

$\mathrm{BRW}=$ bedrock well.

MCL = maximum contaminant level.

$\mathrm{mg} / \mathrm{L}=$ microgram per liter.

$\mathrm{ND}=$ non-detect.

$\mathrm{UNW}=$ unconsolidated zone well.

Recent data (2009) for two of the wells (UNW-057 and UNW-073) show that thallium is no longer detectable in groundwater at these wells. However, four of the existing monitoring wells located downgradient of the fly ash pile have not been sampled in over 10 years, and current concentrations at these wells are unknown. Although the most recent sampling data indicate that the concentrations of metals have declined to acceptable levels, suggesting this is occurring throughout the fly ash pile area, it is unknown if this is the case at all of the wells located at the fly ash pile. 


\subsection{K-770 SCRAP YARD}

The K-770 Scrap Yard, which occupied approximately 30 acres, is located in the southwestern portion of Zone 1 adjacent to the Clinch River (see Fig. 1). The K-770 Scrap Metal Yard began accepting radioactively contaminated or suspected contaminated metals and debris in the $1960 \mathrm{~s}$. The majority of scrap metal at the K-770 Scrap Metal Yard originated from upgrade/improvement programs or demolition of facilities at ETTP, but materials from other DOE facilities also were received.

The K-770 Scrap Removal Project was conducted as part of the Zone 1 Record of Decision (ROD) and began shipping contaminated scrap from the K-770 Scrap Yard to the Environmental Management Waste Management Facility in July 2004. The PCCR (DOE 2007b) was approved in May 2007. Over 48,100 tons of waste materials were shipped for disposal. Following removal of the scrap material from this site, remediation of the soil was initiated. Radiological walkover surveys and soil sampling were used to delineate excavation areas. The remediation entailed both the removal of remnant scrap metal and contaminated soil.

Elements of the conceptual model include surface water transport of contaminants from building slabs and the aboveground scrap yard via overland flow to the Clinch River. Infiltration of precipitation could mobilize and transport constituents in the waste materials to underlying groundwater, which travels a short distance to discharge at the Clinch River. Relatively permeable alluvial sediments in the subsurface likely allow significant surface water/groundwater interactions.

Storm drains $724,730,740,750$, and 760 are the outfalls that drain the specific storm water runoff from the K-770 Scrap Yard. Since 2005, gross alpha activity at these storm drains has ranged from 27 to 134 picocuries per liter $(\mathrm{pCi} / \mathrm{L})$, and gross beta activity has ranged from 23 to $116 \mathrm{pCi} / \mathrm{L}$. Uranium-238 concentrations have ranged from 11 to $60 \mathrm{pCi} / \mathrm{L}$, with the highest concentrations reported for SD-724, which discharges to the Clinch River at the northern end of the Powerhouse Area (Fig. 1).

Exit pathway groundwater monitoring is conducted at the K-770 area where wells UNW-013 and UNW-015 are used to assess radiological groundwater contamination along the Clinch River (Fig. 1). Figure 4 shows the history of measured alpha and beta activity in this area. Analytical results indicate that the alpha activity is largely attributable to uranium isotopes, and well UNW-013 historically contained ${ }^{99} \mathrm{Tc}$ that is a strong beta-emitting radionuclide responsible for the elevated beta activity in that well.

Data collected in March of 2010 show a slight decrease in beta activity in both wells $(24.8 \mathrm{pCi} / \mathrm{L}$ in UNW-013 and $24.0 \mathrm{pCi} / \mathrm{L}$ in UNW-015). Alpha activity in UNW-013 was a non-detect, while the activity in UNW-015 was $24.8 \mathrm{pCi} / \mathrm{L}$, about the same as the last sampling round in 2009. The MCL for alpha activity is $15 \mathrm{pCi} / \mathrm{L}$.

\subsubsection{Data Gaps}

Elevated alpha and beta activities above the MCL are present in two monitoring wells (UNW-013 and UNW-015) located near the Clinch River. Elevated radioactivity in the K-770 wells has been reported since the initial sample collection event in 1987 following their installation in 1986. Historically, concentrations of uranium isotopes have exceeded the derived MCL of $20 \mathrm{pCi} / \mathrm{L}$ at well UNW-015; however, isotopic uranium concentrations have not been determined since 1998. 


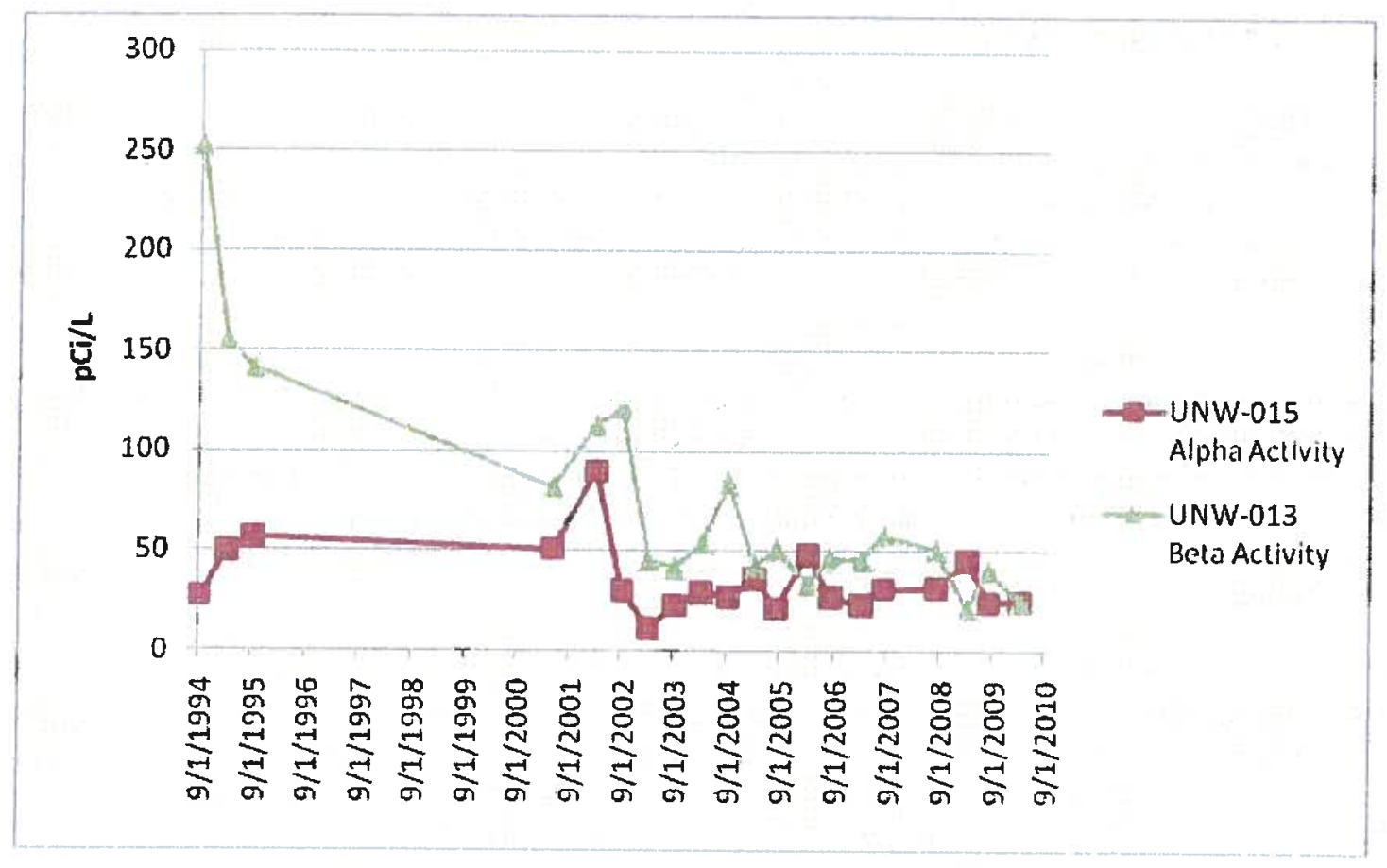

Fig. 4. Radioactivity in groundwater in the K-770 Scrap Yard area.

Figure 4 shows the gross alpha and gross beta activities detected in wells UNW-013 and UNW-015 since 1994. It is suspected that the declining trend in alpha and beta activities evident in Fig. 4 will continue. However, several wells in the K-770 area have not been sampled in over 10 years, and current concentrations are unknown at these wells. Remedial actions recently conducted at the former K-770 Scrap Yard have removed a significant portion of the potential source material, and this is expected to contribute to the continued decline in radiological concentrations in groundwater; however, additional data are necessary to determine if this trend will continue.

\subsection{DUCT ISLAND}

The K-1070-F Construction Spoil Area is an area of approximately 13 acres located in EUs Z1-39, Z1-41, and Z1-42 (Fig. 5). This area operated from the early 1970 s to 1978 for the burial of general construction debris and demolition rubble. There is no evidence from facility records or former employee interviews indicating that hazardous or radioactive constituents were disposed at this landfill site. Of the approximately 13 acres within this Federal Facility Agreement (FFA) site, approximately 5 acres encompass the main landfill site that is covered by a layer of soil. This approximately 5-acre area of the FFA site was classified as a Class 1 Soil Unit (SU). Within this Class 1 SU acreage, there is no visible debris, rubble, or metallic scrap. The area is an open, grassy field. Surrounding the main landfill site are several topographically lower terraces where debris, concrete rubble, and metallic scrap are present on the surface, partially buried, and in some areas covered with a thin layer of soil (based on survey and sampling observation).

The K-900 bottle smasher was located within the boundary of K-1070-F. This former Resource Conservation and Recovery Act of 1976 unit was a thermal treatment unit used for destruction of organic chemicals after burial operations had ceased. The bottle smasher consists of a 3-ft $\times 5-\mathrm{ft} \times 2$-ft-high steel 


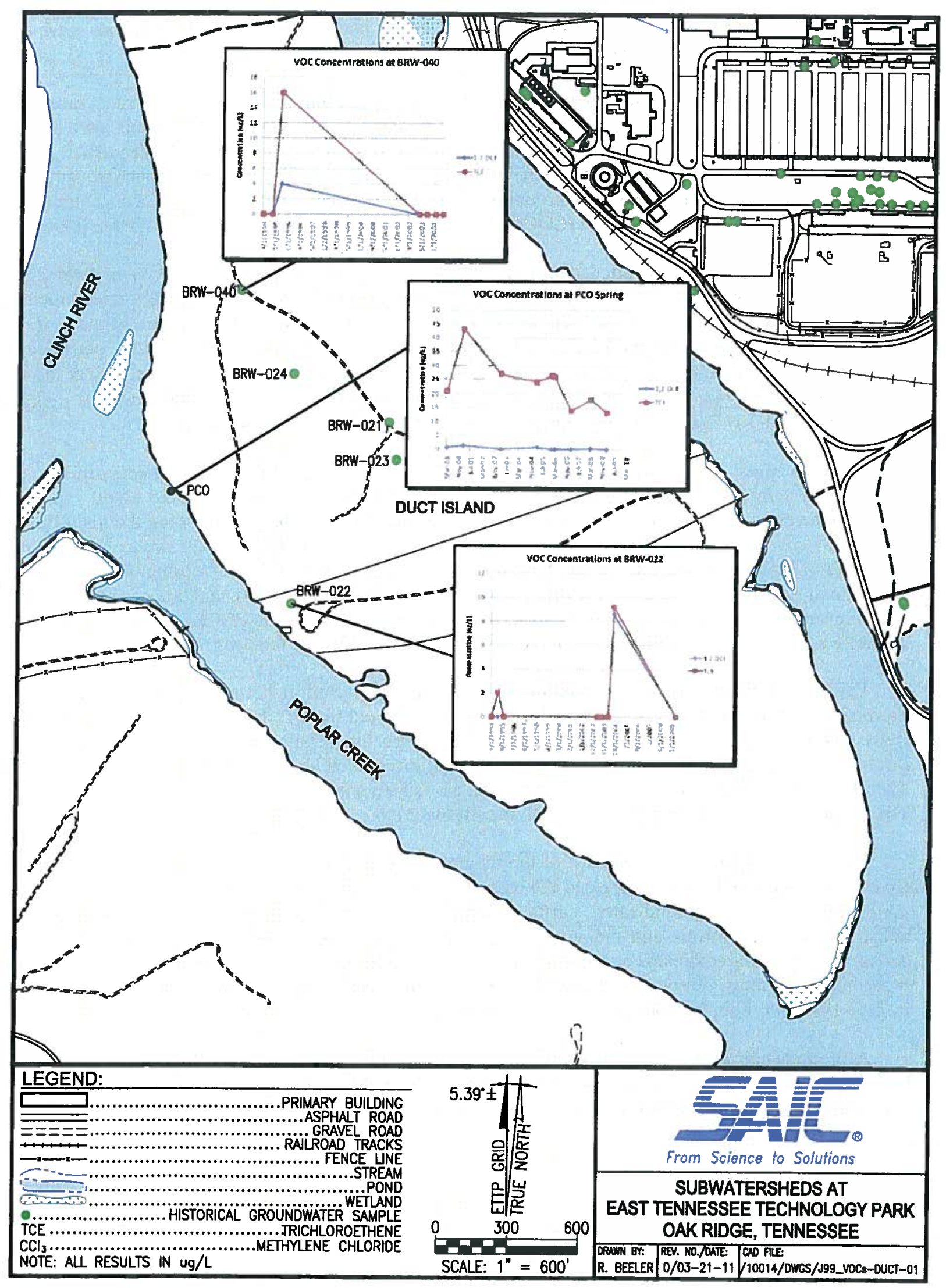

Fig. 5. Maximum concentrations of VOCs exceeding MCLs in the Duct Island subwatershed. 
box with a hinged lid that could be lowered to crush the bottles. The released chemicals were then volatilized by use of a heating element.

Sampling and survey data indicated that there are two mounds of waste materials ranging in thickness to an excess of $10 \mathrm{ft}$ over much of the primary disposal site. The waste materials have elevated metal, polychlorinated biphenyl (PCB), radionuclide, and polycyclic aromatic hydrocarbon (PAH) contaminant concentrations. Concentrations of several metals, PCBs, and radionuclides are above background levels but below industrial preliminary remediation goals (PRGs). Average concentrations of Zone 1 ROD contaminants of concern (COCs) at this site are below industrial use PRGs (DOE 2006a).

No soil samples have reported detections of volatile organic compounds (VOCs) in EUs Z1-39, Z1-40, or Z1-41 that exceed their soil SLs for protection of groundwater. Two VOCs, trichloroethene (TCE) and tetrachloroethene (PCE), were detected in 5 of the 12 Dynamic Verification Strategy (DVS) Class I SU samples analyzed for VOCs. TCE was detected in one sample (67 micrograms per kilogram $[\mu \mathrm{g} / \mathrm{kg}])$ at location EU41B-117. PCE was detected in the remaining four samples: $95 \mu \mathrm{g} / \mathrm{kg}$ at location EU39B-114; $210 \mu \mathrm{g} / \mathrm{kg}$ at location EU41-103; $130 \mu \mathrm{g} / \mathrm{kg}$ at location EU41B-118; and $91 \mu \mathrm{g} / \mathrm{kg}$ at location EU41M-107. No VOCs were detected in either the EU Z1-40 or Z1-41 soils.

The conceptual site model (CSM) for the K-1070-F Landfill is a landfill with a soil cap scenario. Surveys and sampling of the landfill site indicated that the main fill area does have a soil cap (DOE 2006b). However, there is extensive disposal of building rubble and debris surrounding the main fill area that is not covered. Surveys and soil cores from the site have confirmed the presence of substantial quantities of building debris and rubble. Subsurface obstructions to Geoprobe ${ }^{1}{ }^{1}$ coring were common in some small sections of the main fill area. Sample results indicate contaminant impact from disposal operations are below Zone 1 risk levels. The CSM model presented in the PCCR for Duct Island (DOE 2006b) was slightly modified to represent the portion of the landfill site that was not covered.

Drilling for installation of the monitoring wells and geotechnical borings drilled for the Toroidal Fusion Core Facility (TFCF) indicated bedrock was encountered from $15 \mathrm{ft}$ to $68 \mathrm{ft}$ below ground surface (bgs). Bedrock consisted primarily of limestone with interbedded shale encountered in some boreholes. Mud-filled cavities were encountered in two of the monitoring well boreholes (BRW-021 and BRW-024). The TFCF borings indicate that the depth of the fill associated with $\mathrm{K}-1070-\mathrm{F}$ varies from 0 to $23.5 \mathrm{ft}$ bgs. The thickness of the undisturbed soil beneath the fill materials ranges from $7 \mathrm{ft}$ to over $40 \mathrm{ft}$.

Duct Island occupies an area west of the main plant area of the ETTP. It is bounded by the Clinch River to the northwest; Poplar Creek to the east, south, and west; and the K-901-A Holding Pond to the north. Movement of groundwater, surface water, and sediments is the primary mechanism for redistribution of chemicals and radionuclides into other media in this subwatershed. As there are no perennial surface water streams or a storm drain network in the area, surface water and sediment transport is accomplished mostly through overland flow. This would be most important in transporting constituents from K-1070-F to Poplar Creek and the Clinch River.

A groundwater divide runs northwest to southeast along the ridgecrest located in the center of the Duct Island area. This divide directs shallow groundwater flow either generally to the east and west toward Poplar Creek or west toward the Clinch River. Because these water bodies represent local base

\footnotetext{
${ }^{1}$ Reference herein to any specific commercial product, process, or service by trade name, trademark, manufacturer, or otherwise, does not necessarily constitute or imply its endorsement, recommendation, or favoring by the United States Government or any agency thereof or its contractors or subcontractors.
} 
level for groundwater, constituents transported by groundwater are discharged to Poplar Creek or the Clinch River after following short flow paths.

The source of VOCs in the PCO Spring discharge along the shore of Poplar Creek is unknown; however, the K-1070-F Construction Spoil Area represents the likely source based on its upgradient location. Soil data are insufficient to determine if $\mathrm{K}-1070-\mathrm{F}$ soils contribute to this contamination due to the shallow depths of investigation. Although the source of the SVOCs detected in well BRW-022 is also unknown, the results are considered to be suspect based on analysis presented in the Sitewide RI (DOE 1999). Given the limited mobility of SVOCs in soils, it is unlikely that these constituents would be transported through the soil column to the underlying groundwater. The detection in the 1994 and 1995 time frame of bis(2-ethylhexyl)phthalate in groundwater samples from K-1070-F is thought to be a sampling artifact as the detection of this compound was essentially ubiquitous throughout the ETTP during those sampling events.

Monitoring data are available for the K-1070-F Construction Spoil Area from five wells (BRW-021, BRW-022, BRW-023, BRW-024, and BRW-040) and the PCO Spring. Table 3 shows the concentrations of selected VOCs at the PCO Spring, and Table 4 shows the concentrations of selected VOCs and SVOCs in groundwater wells based on sampling results from 1994 to present. The trend of TCE concentrations over time at the PCO Spring is plotted in Fig. 6.

Table 3. Selected VOCs detected in the PCO Spring on Duct Island

\begin{tabular}{|c|c|c|c|c|c|}
\hline \multirow[b]{3}{*}{ Location } & \multirow[b]{2}{*}{ MCL } & 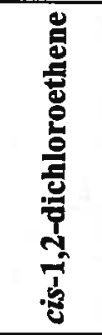 & 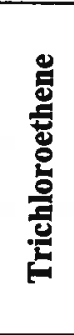 & 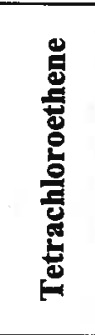 & 总 \\
\hline & & 70 & 5 & 5 & 2 \\
\hline & Date sampled & \multicolumn{4}{|c|}{ Result ( $\mu \mathrm{g} / \mathrm{L})$} \\
\hline PCO & $3 / 06 / 00$ & 0.6 & 21 & ND & ND \\
\hline \multirow[t]{9}{*}{ Spring } & 2/07/01 & 1.3 & 43 & ND & ND \\
\hline & $3 / 25 / 2003$ & ND & 27 & ND & ND \\
\hline & $3 / 15 / 2005$ & $0.77 \mathrm{~J}$ & 24 & $1 \mathrm{U}$ & $1 \mathrm{U}$ \\
\hline & 1/12/06 & ND & 26.5 & $1 \mathrm{U}$ & ND \\
\hline & $3 / 7 / 2006$ & $1 \mathrm{U}$ & 26 & ND & $1 \mathrm{U}$ \\
\hline & $2 / 5 / 2007$ & $5 \mathrm{U}$ & 14 & $5 \mathrm{U}$ & $2 \mathrm{U}$ \\
\hline & $3 / 13 / 2008$ & $0.2 \mathrm{~J}$ & 18 & $2 U$ & $1 \mathrm{U}$ \\
\hline & $2 / 26 / 2009$ & $5 \mathrm{U}$ & 13.2 & $2.5 \mathrm{U}$ & $1 \mathrm{U}$ \\
\hline & $3 / 01 / 10$ & $1 \mathrm{U}$ & 9 & $1 \mathrm{U}$ & $1 \mathrm{U}$ \\
\hline
\end{tabular}

Bold denotes results exceeding MCL.

$\mathrm{J}=$ estimated concentration.

$\mathrm{MCL}=$ maximum contaminant level.

$\mathrm{ND}=$ non-detect.

$\mathrm{U}=$ constituent not detected above indicated concentration.

VOC $=$ volatile organic compound.

$\mu \mathrm{g} / \mathrm{L}=$ microgram per liter. 
Table 4. Selected constituents detected in groundwater wells at the K-1070-F Construction Spoil Area

\begin{tabular}{|c|c|c|c|c|c|c|c|}
\hline & & 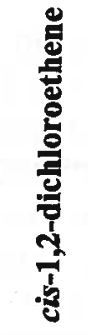 & 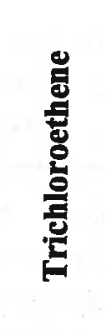 & 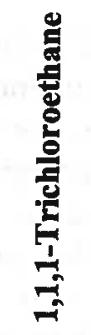 & 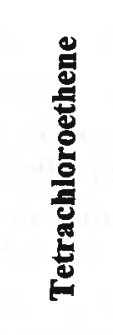 & 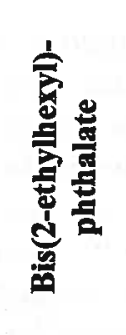 & 踢 \\
\hline & MCL & 70 & 5 & 200 & 5 & 6 & 2 \\
\hline Well & Date sampled & \multicolumn{6}{|c|}{ Result $(\mu \mathrm{g} / \mathrm{L})$} \\
\hline BRW-021 & $\begin{array}{c}9 / 29 / 94 \\
3 / 2 / 95 \\
9 / 15 / 95 \\
4 / 14 / 03 \\
9 / 29 / 03 \\
3 / 20 / 04 \\
9 / 23 / 04 \\
\end{array}$ & $\begin{array}{l}5 \mathrm{U} \\
5 \mathrm{U} \\
5 \mathrm{U} \\
2 \mathrm{U} \\
2 \mathrm{U} \\
1 \mathrm{U} \\
1 \mathrm{U}\end{array}$ & $\begin{array}{l}5 U \\
5 U \\
3 J \\
2 U \\
2 U \\
1 U \\
1 U \\
\end{array}$ & $\begin{array}{l}5 \mathrm{U} \\
5 \mathrm{U} \\
5 \mathrm{U} \\
2 \mathrm{U} \\
2 \mathrm{U} \\
1 \mathrm{U} \\
1 \mathrm{U} \\
\end{array}$ & $\begin{array}{l}5 \mathrm{U} \\
5 \mathrm{U} \\
5 \mathrm{U} \\
2 \mathrm{U} \\
2 \mathrm{U} \\
1 \mathrm{U} \\
1 \mathrm{U} \\
\end{array}$ & $\begin{array}{l}12 \mathrm{~J} \\
67 \\
\text { NA } \\
\text { NA } \\
\text { NA } \\
\text { NA } \\
\text { NA } \\
\end{array}$ & $\begin{array}{l}3.1 \mathrm{U} \\
2.8 \mathrm{U} \\
3.3 \mathrm{U} \\
\mathrm{NA} \\
\mathrm{NA} \\
\mathrm{NA} \\
\mathrm{NA} \\
\end{array}$ \\
\hline $\begin{array}{c}\text { BRW-022 } \\
\text {. }\end{array}$ & $\begin{array}{l}9 / 30 / 94 \\
3 / 27 / 95 \\
9 / 18 / 95 \\
4 / 10 / 03 \\
9 / 29 / 03 \\
3 / 26 / 04 \\
8 / 30 / 04 \\
9 / 14 / 09 \\
\end{array}$ & $\begin{array}{l}5 U \\
5 U \\
5 U \\
2 U \\
2 U \\
1 U \\
8.6 \\
5 U \\
\end{array}$ & $\begin{array}{c}5 \mathrm{U} \\
2 \mathrm{~J} \\
5 \mathrm{U} \\
2 \mathrm{U} \\
2 \mathrm{U} \\
1 \mathrm{U} \\
9.2 \\
2.5 \mathrm{U} \\
\end{array}$ & $\begin{array}{l}5 \mathrm{U} \\
5 \mathrm{U} \\
5 \mathrm{U} \\
2 \mathrm{U} \\
2 \mathrm{U} \\
1 \mathrm{U} \\
1 \mathrm{U} \\
5 \mathrm{U}\end{array}$ & $\begin{array}{c}5 \mathrm{U} \\
5 \mathrm{U} \\
5 \mathrm{U} \\
2 \mathrm{U} \\
2 \mathrm{U} \\
1 \mathrm{U} \\
0.17 \mathrm{~J} \\
2.5 \mathrm{U} \\
\end{array}$ & $\begin{array}{l}40 \mathrm{~J} \\
650 \\
270 \\
\text { NA } \\
\text { NA } \\
\text { NA } \\
\text { NA } \\
\text { NA } \\
\end{array}$ & $\begin{array}{c}3.1 \mathrm{U} \\
3.1 \mathrm{U} \\
3.4 \\
\mathrm{NA} \\
\mathrm{NA} \\
\mathrm{NA} \\
\mathrm{NA} \\
\mathrm{NA} \\
\end{array}$ \\
\hline BRW-023 & $\begin{array}{c}9 / 28 / 94 \\
3 / 3 / 95 \\
10 / 4 / 95 \\
4 / 10 / 03 \\
9 / 25 / 03 \\
3 / 31 / 04 \\
8 / 30 / 04 \\
9 / 15 / 09 \\
\end{array}$ & $\begin{array}{l}5 U \\
5 U \\
5 U \\
2 U \\
2 U \\
1 U \\
1 U \\
N A \\
\end{array}$ & $\begin{array}{l}5 U \\
5 U \\
5 U \\
2 U \\
2 U \\
1 U \\
1 U \\
\text { NA }\end{array}$ & $\begin{array}{l}2 \mathrm{~J} \\
5 \mathrm{U} \\
2 \mathrm{~J} \\
2 \mathrm{U} \\
2 \mathrm{U} \\
1 \mathrm{U} \\
1 \mathrm{U} \\
\mathrm{NA}\end{array}$ & $\begin{array}{l}5 \mathrm{U} \\
5 \mathrm{U} \\
5 \mathrm{U} \\
2 \mathrm{U} \\
2 \mathrm{U} \\
1 \mathrm{U} \\
1 \mathrm{U} \\
\mathrm{NA}\end{array}$ & $\begin{array}{l}160 \\
200 \\
\text { NA } \\
\text { NA } \\
\text { NA } \\
\text { NA } \\
\text { NA } \\
\text { NA } \\
\end{array}$ & $\begin{array}{l}3.1 \mathrm{U} \\
2.8 \mathrm{U} \\
4.1 \mathrm{U} \\
\mathrm{NA} \\
\mathrm{NA} \\
\mathrm{NA} \\
\mathrm{NA} \\
1 \mathrm{U} \\
\end{array}$ \\
\hline BRW-024 & $\begin{array}{l}9 / 30 / 94 \\
3 / 27 / 95 \\
9 / 25 / 95 \\
4 / 10 / 03 \\
9 / 29 / 03 \\
3 / 26 / 04 \\
8 / 30 / 04 \\
\end{array}$ & $\begin{array}{l}5 U \\
5 U \\
5 U \\
2 U \\
2 U \\
1 U \\
1 U\end{array}$ & $\begin{array}{l}5 U \\
5 U \\
5 U \\
2 U \\
2 U \\
1 U \\
1 U \\
\end{array}$ & $\begin{array}{l}5 \mathrm{U} \\
5 \mathrm{U} \\
5 \mathrm{U} \\
2 \mathrm{U} \\
2 \mathrm{U} \\
1 \mathrm{U} \\
1 \mathrm{U} \\
\end{array}$ & $\begin{array}{l}5 U \\
5 U \\
5 U \\
2 U \\
2 U \\
1 U \\
1 U \\
\end{array}$ & $\begin{array}{c}330 \\
79 \\
\text { NA } \\
\text { NA } \\
\text { NA } \\
\text { NA } \\
\text { NA } \\
\end{array}$ & $\begin{array}{c}3.1 \mathrm{U} \\
3.3 \mathrm{U} \\
4.1 \mathrm{U} \\
\mathrm{NA} \\
\mathrm{NA} \\
\mathrm{NA} \\
\mathrm{NA} \\
\end{array}$ \\
\hline BRW-040 & $\begin{array}{c}9 / 28 / 94 \\
3 / 2 / 95 \\
9 / 15 / 95 \\
4 / 10 / 03 \\
9 / 29 / 03 \\
3 / 30 / 04 \\
9 / 23 / 04 \\
\end{array}$ & $\begin{array}{l}5 \mathrm{U} \\
5 \mathrm{U} \\
4 \mathrm{~J} \\
2 \mathrm{U} \\
2 \mathrm{U} \\
1 \mathrm{U} \\
1 \mathrm{U} \\
\end{array}$ & $\begin{array}{c}5 U \\
5 U \\
16 \\
2 U \\
2 U \\
1 U \\
1 U \\
\end{array}$ & $\begin{array}{l}\mathrm{U} \\
5 \mathrm{U} \\
5 \mathrm{U} \\
2 \mathrm{U} \\
2 \mathrm{U} \\
1 \mathrm{U} \\
1 \mathrm{U} \\
\end{array}$ & $\begin{array}{l}5 U \\
5 U \\
5 U \\
2 U \\
2 U \\
1 U \\
1 U \\
\end{array}$ & $\begin{array}{c}170 \mathrm{~J} \\
380 \\
\text { NA } \\
\text { NA } \\
\text { NA } \\
\text { NA } \\
\text { NA } \\
\end{array}$ & $\begin{array}{c}3.1 \mathrm{U} \\
2.8 \mathrm{U} \\
3.3 \mathrm{U} \\
\mathrm{NA} \\
\mathrm{NA} \\
\mathrm{NA} \\
\mathrm{NA} \\
\end{array}$ \\
\hline
\end{tabular}

Bold denotes results exceeding MCL.

BRW = bedrock well.

NA $=$ not applicable.

$\mathrm{J}=$ estimated concentration.

$\mathrm{MCL}=$ maximum contaminant level.

$\mathrm{U}=$ constituent not detected above indicated concentration.

$\mu \mathrm{g} / \mathrm{L}=$ microgram per liter. 


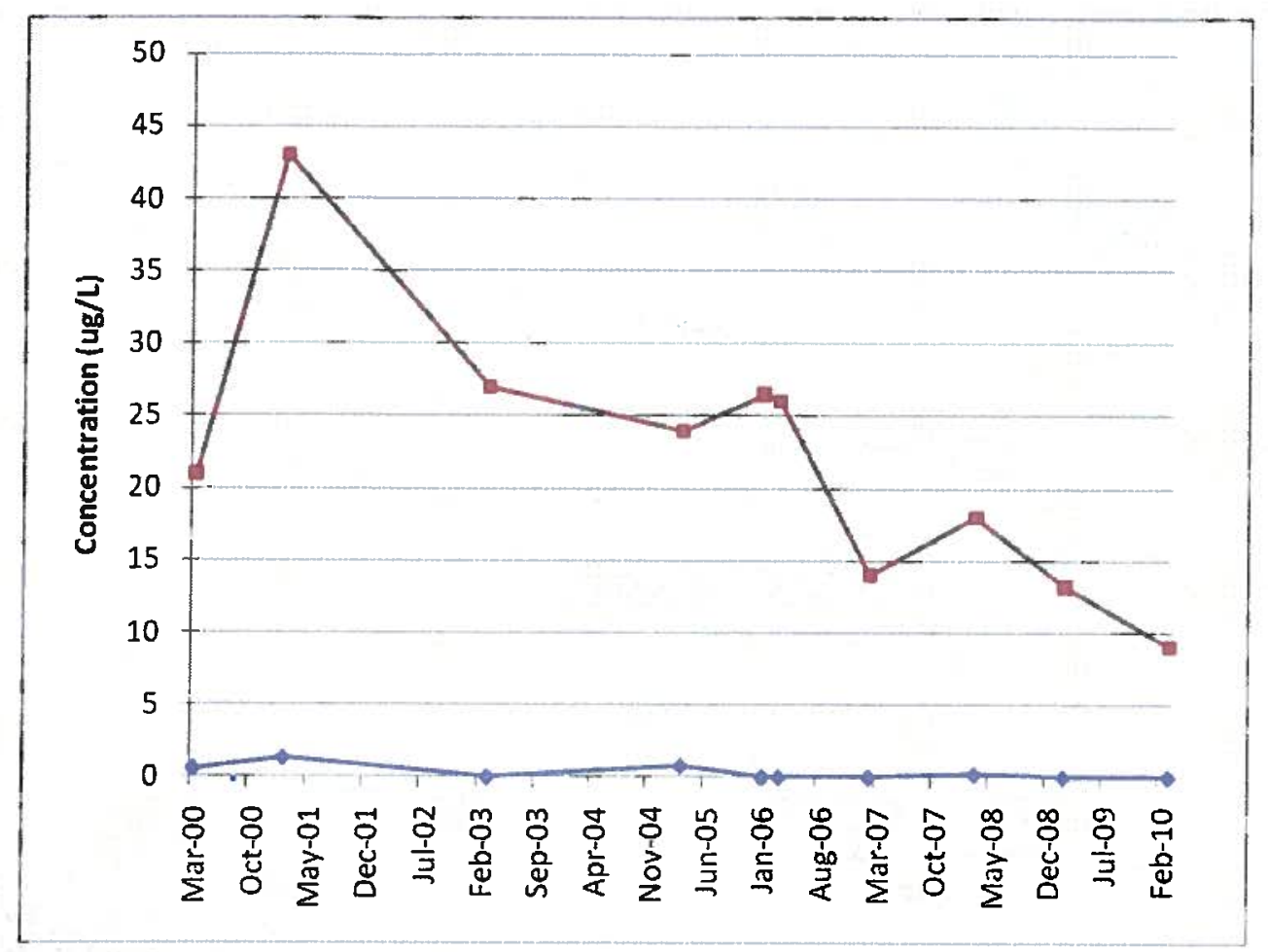

Fig. 6. VOC concentrations at the PCO Spring.

\subsubsection{Data Gaps}

TCE is detected at the PCO Spring on the bank of Poplar Creek at concentrations above the MCL (13 $\mu \mathrm{g} / \mathrm{L}$ in the most recent sample). However, a decreasing trend in TCE concentration over the past 10 years is evident at the spring. The K-1070-F Construction Spoil Area is located upgradient of the spring, but TCE has not been detected in the existing wells in the most recent groundwater samples collected.

The exact source of the TCE present at the spring is uncertain; however, based on the low concentrations present and the decreasing concentration trend over the past 10 years, it is suspected that attenuation of the TCE will continue. However, additional data collection will be needed to confirm the continuation of the declining trend in TCE concentrations at the spring.

\subsection{K-1085 FIREHOUSE BURN/J.A. JONES MAINTENANCE AREA}

The K-1085 Old Firehouse Burn Area is located in EU Z1-09, along with the K-1085 Old Firehouse Burn Area Drum Burial Site and the former J.A. Jones Maintenance Complex (Fig. 7).

A Time-critical Removal Action (TcRmA) was performed in 2001 in response to the discovery of buried drums during roadwork activities conducted by the Tennessee Department of Transportation (TDOT). The removal action included radiological and geophysical surveys, limited soil sampling for characterization, excavation of drums and discolored soil to a depth of approximately $7 \mathrm{ft}$, sampling of drum contents, waste transportation and disposal, verification sampling after excavation, and backfilling with clean soil of the excavated areas. 


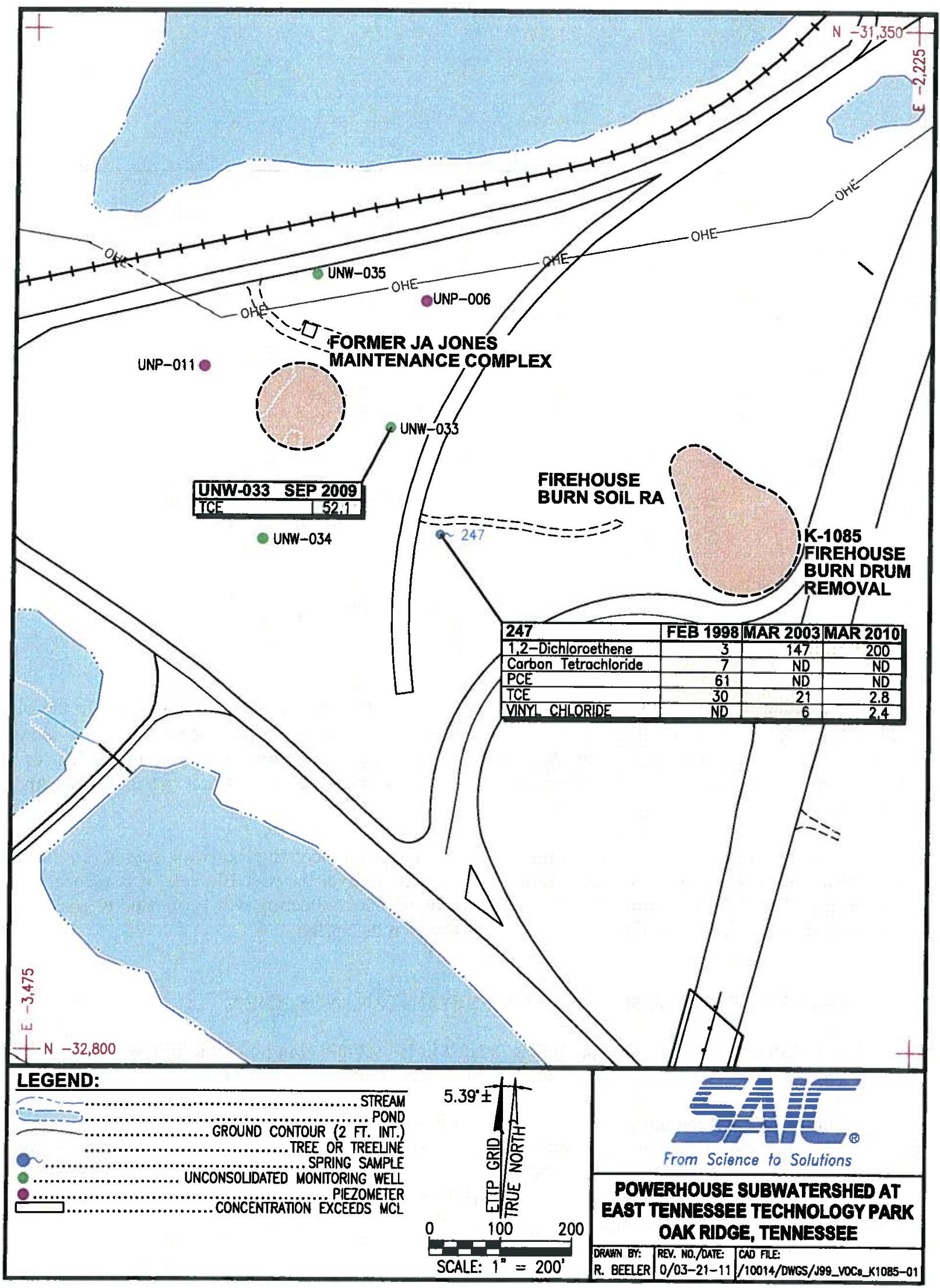

Fig. 7. Maximum concentrations of selected VOCs, K-1085 Firehouse Burn and J. A. Jones Areas. 
Residual soils analytical results indicated the presence of several VOCs, including 1,1-dichloroethene (DCE), 1,2-DCE, acetone, benzene, carbon tetrachloride, chlorobenzene, chloroform, dimethylbenzene, ethylbenzene, PCE, toluene, TCE, and vinyl chloride. Detected soil concentrations of PCE ranged from $9800 \mu \mathrm{g} / \mathrm{kg}$ to $570,000 \mu \mathrm{g} / \mathrm{kg}$, and TCE ranged from $69 \mu \mathrm{g} / \mathrm{kg}$ to $33,000 \mu \mathrm{g} / \mathrm{kg}$ (DOE 2002). Subsequent to the TcRmA, soil samples collected under the DVS confirmed that residual soils contained VOCs at concentrations in excess of the groundwater SLs.

The area underwent a soil remedial action (DOE 2010) to remove VOC- and PCB-contaminated soil in 2008. As part of the remedial action activities, additional soil sampling and field measurements were conducted to better define the extent of contamination and characterize the soil for disposal. Results of soil samples collected to assess potential VOC contamination indicated the greatest concentration of VOCs (highest values range from 16,000 to $49,000 \mu \mathrm{g} / \mathrm{kg}$ TCE) was within the depth interval of 8 to $12 \mathrm{ft}$. Analytical results indicated that the highest concentration of PCBs was found at the depth of $12 \mathrm{ft}$ (highest values ranged from 44,000 to $360,000 \mu \mathrm{g} / \mathrm{kg}$ PCB-1254 in the 12 to 12.2 -ft-depth interval). Groundwater was not encountered during any of sampling activities, including one boring that was advanced to a depth of $32 \mathrm{ft}$. The remedial action Core Team concurred that the depth of soil excavation over the burn pit area should be to $12 \mathrm{ft}$ below grade (DOE 2010). Final determination for this EU after completion of the remedial action is no further action (NFA).

Two underground storage tanks (USTs) [H14 and H15] at the J.A. Jones Maintenance Area were closed in July 2007. Prior to closure, tank H15 was found to be empty; however, tank H14 was nearly full of clear liquid (water) and was sampled for disposition. Sample results indicated the presence of xylene (6800 micrograms per liter $[\mu \mathrm{g} / \mathrm{L}])$, benzene $(33,000 \mu \mathrm{g} / \mathrm{L})$, naphthalene $(530 \mu \mathrm{g} / \mathrm{L}), 1,2$-dichloroethane $(1800 \mu \mathrm{g} / \mathrm{L})$, and toluene $(18,000 \mu \mathrm{g} / \mathrm{L})$. Tank closures were performed in accordance with UST rules of TDEC Chap. 1200-1-15-.07. Results from tank H14 downgradient soil sampling did not support the need to excavate additional downgradient soils.

Elements of the conceptual model include movement of VOCs vertically beneath the Burn Area to the water table. Some lateral movement appears to have occurred with discharge of VOCs in the nearby 247 Spring. The presence of near vertical bedding was reported for the area based on observations during the remedial action (DOE 2010).

Groundwater monitoring locations in the area include Spring 247, and five groundwater wells located across Bear Creek Road in the vicinity of the Former J.A. Jones Maintenance Complex (Fig. 7).

TDEC and/or the ETTP Water Quality Program (EWQP) have sampled Spring 247 since 1998. Contaminants include TCE and daughter products (cis-1,2-DCE and vinyl chloride). TCE concentrations have decreased from $30 \mu \mathrm{g} / \mathrm{L}$ to $2.8 \mu \mathrm{g} / \mathrm{L}$ in 2010. Cis-1,2-DCE has increased from $147 \mu \mathrm{g} / \mathrm{L}$ in 2003 to 200 $\mu \mathrm{g} / \mathrm{L}$ in 2010 (Fig. 8). Other VOC compounds detected in 1998 (vinyl chloride, PCE, and carbon tetrachloride) have been non-detects in subsequent sampling.

Monitoring well UNW-033 was sampled in September 2009. TCE was detected at a concentration of $52.1 \mu \mathrm{g} / \mathrm{L}$ at this well, which is higher than any of the 247 Spring samples. The only other reported detection of TCE at this well was an estimated concentration of $2 \mu \mathrm{g} / \mathrm{L}$ in 1987. 


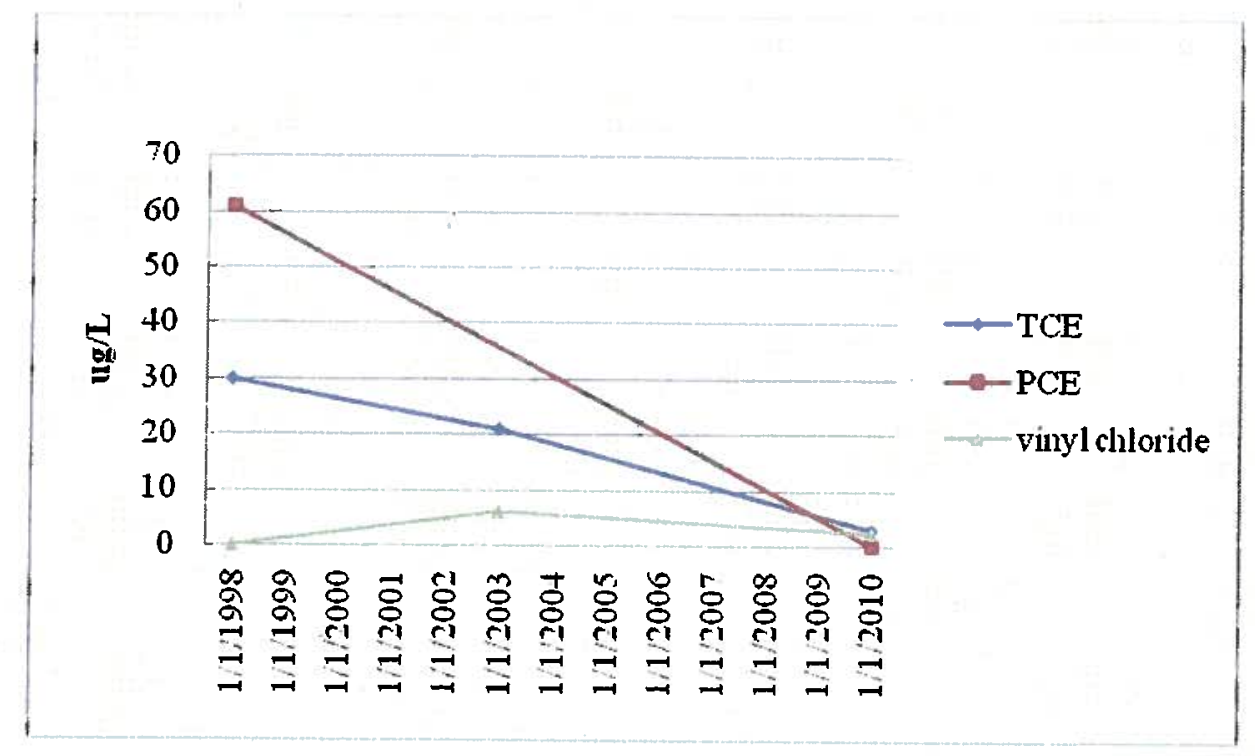

Fig. 8. VOC concentrations at Spring 247.

\subsubsection{Data Gaps}

Concentrations of VOCs (TCE and the degradation product 1,2-DCE) are detectable in seepage areas (Spring 247) downgradient of the K-1085 Firehouse Burn Area and the J.A. Jones Maintenance Complex. TCE has also been detected in the most recent sampling event at one well in this area.

The exact source of the VOCs in the K-1085 area is uncertain; however, the K-1085 Firehouse Burn Area is a likely contributor based on historical soil investigations. Two of the five existing wells in this area have not been sampled in over 10 years. The 2009 sample at well UNW-033 that contained TCE $(52 \mu \mathrm{g} / \mathrm{L})$ is the only detection of VOCs in the past 20 years at this well. Although TCE degradation products are present at the spring, none were detected at UNW-033 in 2009. The extent of groundwater contamination in the K-1085 Firehouse Burn Area has not been identified. The seepage area designated as Spring 247 is the only data point for shallow groundwater quality in the K-1085 Firehouse Burn Area portion of the site. Also, given the subsurface soil data collected during the remedial actions and the observed soil conditions, there is the potential that contaminants have reached bedrock; however, no bedrock wells exist in the K-1085 Firehouse Burn and the J.A. Jones Maintenance Area.

\subsection{CONTRACTOR'S SPOIL AREA}

Located in EUs 66, 69, and 70 in the northernmost extent of Zone 1 (mostly within EUs 70 and 66), the Contractor's Spoil Area (CSA) consists of a construction debris and fly ash landfill (Fig. 9) covering approximately 15 acres. There is a soil cover over most of the area. It is located within the Blackoak Ridge Conservation Easement (BORCE).

EUs 69 and 74 were given an NFA determination based on historical and DVS data (DOE 2006b). Further investigation of EUs 66 and 70 indicated that the cumulative risks for the industrial scenario exceed the ROD-established criteria of Zone 1 soils $\left(1 \times 10^{-4}\right)$. However, because of the inclusion of the 


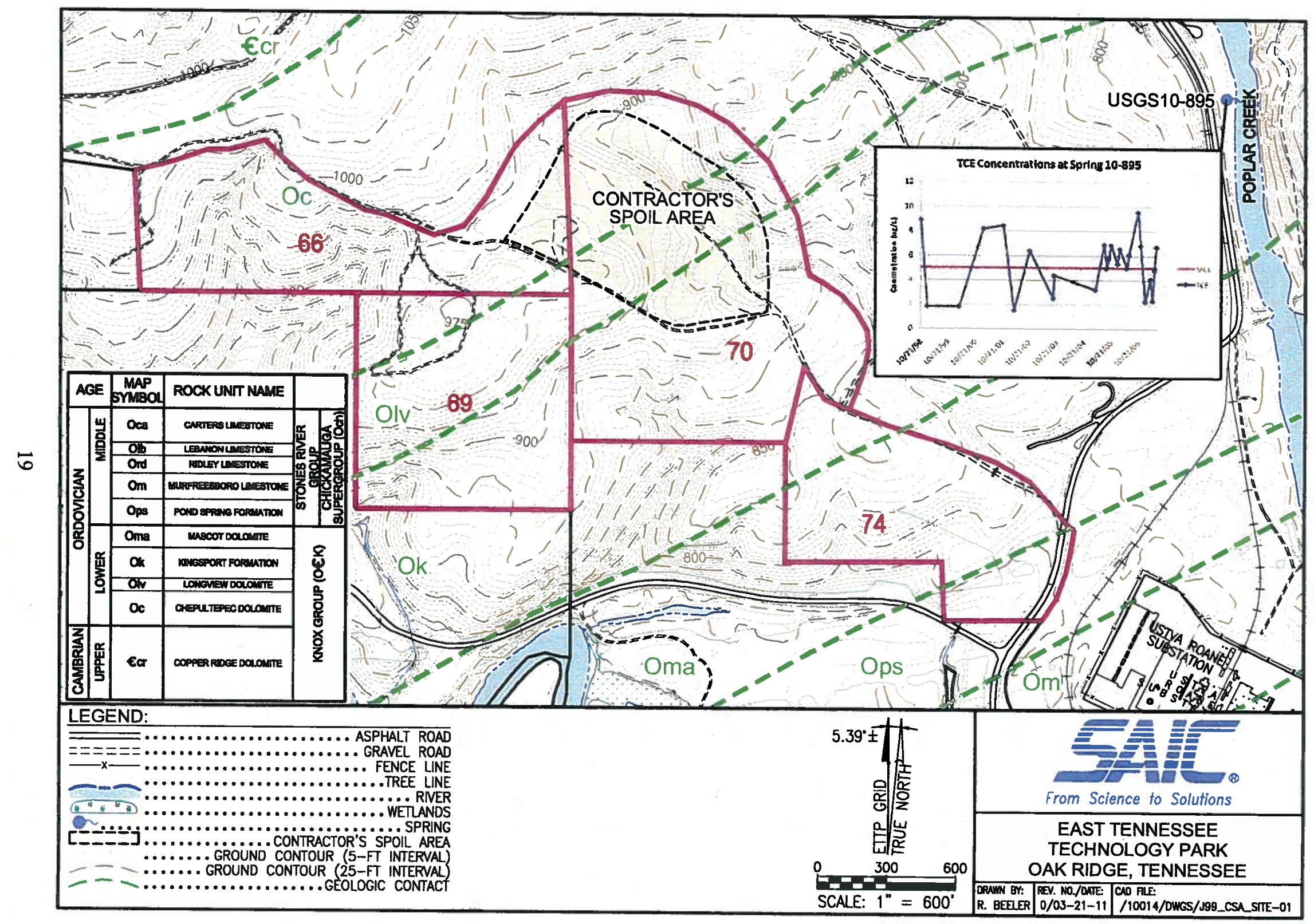

Fig. 9. Contractor's Spoil Area site map. 
CSA in the BORCE, a supplemental risk assessment was conducted using the recreational scenario, concluding that there is no unacceptable risk to the recreational user (DOE 2009).

Elements of the conceptual model include a landfill area mostly covered by a soil cap. Surface water transport includes overland flow and movement via an unnamed stream along the northern boundary of the CSA. Infiltration of precipitation could mobilize and transport constituents in the waste materials to groundwater.

Shallow groundwater flow is expected to follow topography and discharge to the intermittent stream flowing from northwest to southeast along the northern toe of the CSA, and possibly discharging directly to Poplar Creek to the southeast. Groundwater flow in bedrock likely follows solution-enlarged features such as bedding planes and fractures, both along strike and down-dip toward Poplar Creek.

A radiological walkover survey conducted under the DVS found no areas of surface soil radiological contamination. Soil samples from the CSA identified nine metals (antimony, arsenic, cadmium, copper, chromium, mercury, nickel, thallium, and vanadium) above residential PRGs. PCBs (Arochlor-1254 and Arochlor-1260) were detected in seven samples with two results exceeding industrial PRGs and results exceeding the Zone 1 average remediation level (RL). Radium, thorium, and uranium were frequently detected above background levels with two samples for ${ }^{226} \mathrm{Ra}$ exceeding its average RL. Eight SVOCs were frequently detected in the landfill materials with concentrations exceeding industrial PRGs. VOCs were detected, but none exceeded industrial PRGs or the groundwater protection SLs.

Fourteen soil arsenic results and two chromium results exceeded their groundwater protection SL criteria $(66.3 \mathrm{mg} / \mathrm{kg}$ and $172 \mathrm{mg} / \mathrm{kg}$, respectively).

Eighty-three soil samples were field screened for VOC contamination and 50 soil samples were submitted for laboratory analysis for TCE. TCE was not detected in any soil samples collected from either the 0 to $10 \mathrm{ft}$ bgs ( 43 samples), or below $10 \mathrm{ft}$ ( 7 samples). Technetium- 99 was detected in 7 out of 59 soil samples with a maximum concentration of 77 picocuries per gram $(\mathrm{pCi} / \mathrm{g})$.

Samples from the U. S. Geological Survey 10-895 spring, located on the bank of Poplar Creek to the east, have indicated the presence of TCE at, or slightly above, MCL concentrations $(5 \mu \mathrm{g} / \mathrm{L})$. Technetium-99, ranging from -3.5 to $11.4 \mathrm{pCi} / \mathrm{L}$, has also been detected. The source of these contaminants is unknown.

There are no groundwater wells in the CSA area. Spring 10-895 has been sampled since the late 1990s; however, the source of the TCE contamination cannot be determined for certain. Concentrations have ranged from $<2 \mu \mathrm{g} / \mathrm{L}$ to $9 \mu \mathrm{g} / \mathrm{L}$ over the past 9 years with a steady trend (Fig. 10).

\subsubsection{Data Gaps}

TCE is detected at Spring 10-895 on the bank of Poplar Creek at concentrations either slightly above, or slightly below, the MCL ( 2 to $9 \mu \mathrm{g} / \mathrm{L}$ ). The CSA is the nearest waste management unit and is also located along geologic strike and upgradient of the spring; thus, the CSA is a potential source for the TCE. 


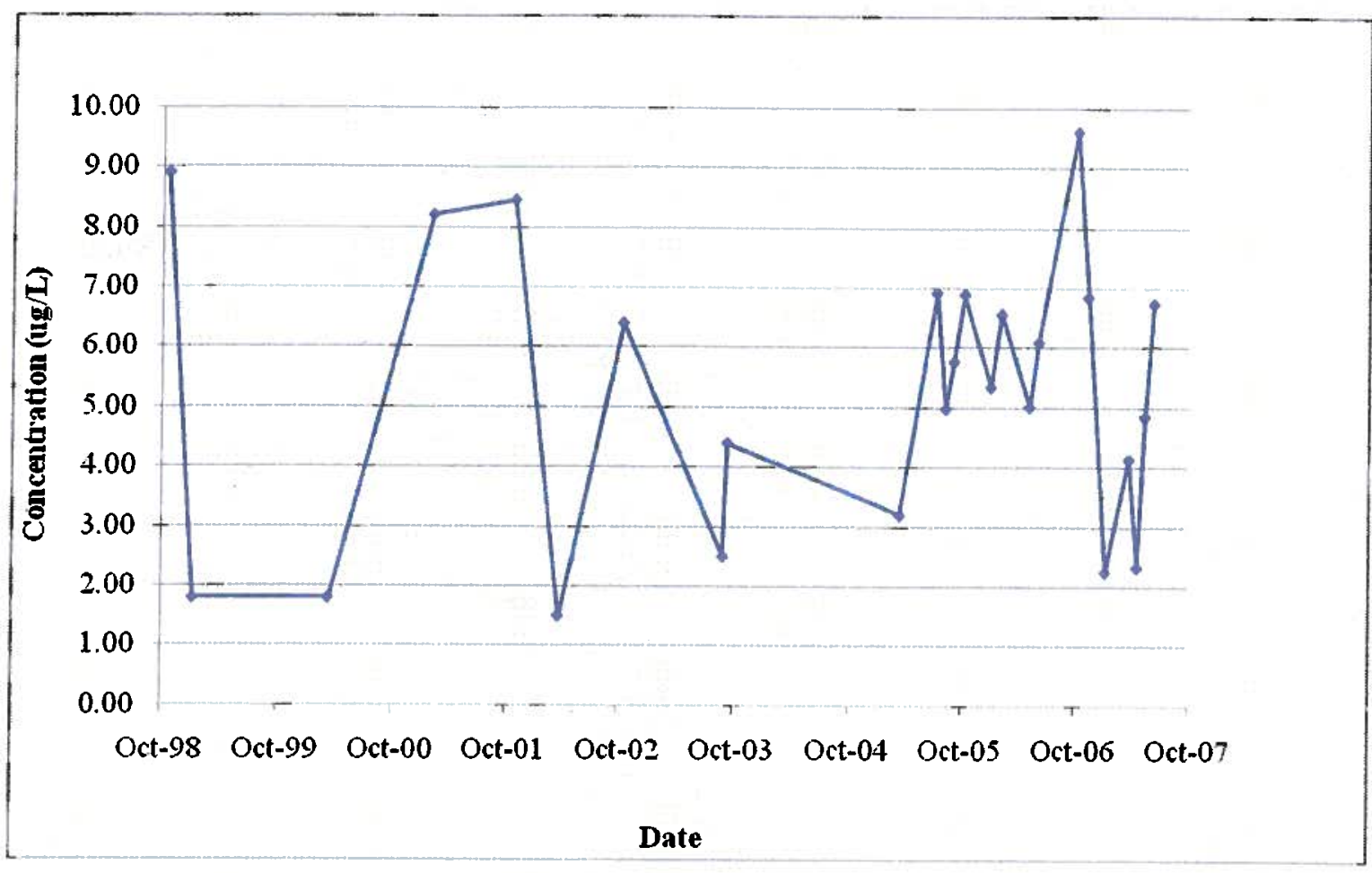

Fig. 10. TCE concentrations at Spring 10-895.

Although the CSA is a suspected source of the TCE at Spring 10-895, the actual source remains uncertain based on the absence of TCE in the DVS soil samples collected at the CSA. It is suspected that concentrations of TCE at the spring will continue to exceed the MCL only periodically based on the current trend (see Fig. 10). In 10 years of monitoring, TCE concentrations have not exceeded $9.6 \mu \mathrm{g} / \mathrm{L}$. Additional data from the spring will be needed to confirm the observed concentration trend. Additional data collection at the CSA is also needed to determine the likelihood of this site being the source of the TCE.

\subsection{FORMER K-1070-A BURIAL GROUND}

The K-1070-A Old Contaminated Burial Ground, located on the flank of Blackoak Ridge and to the northeast of the K-901 Holding Pond (Figs. 11 and 12), is the primary historical source of contamination at the K-901 geographic area. VOCs are the primary contaminants in the groundwater of this area.

Based on the Sitewide RI (DOE 2007a), a single groundwater contaminant plume was delineated that originates at the K-1070-A Old Contaminated Burial Ground and extends downgradient to Spring 21-002, located approximately $1700 \mathrm{ft}$ south of the burial ground. Fate and transport analysis had shown that the groundwater concentrations in this plume would decrease to below the MCL within 40 years from calendar year 2005 assuming the source of contamination had been removed. The previous analysis was performed using the groundwater data from the shallow, unconsolidated wells as well as from the deep bedrock wells for the period between 1994 and 2005. The analysis has been revised in this study based on groundwater data from the same wells, but extending the period of observations to February/March 2010. The summary of this revised analysis is provided below. 


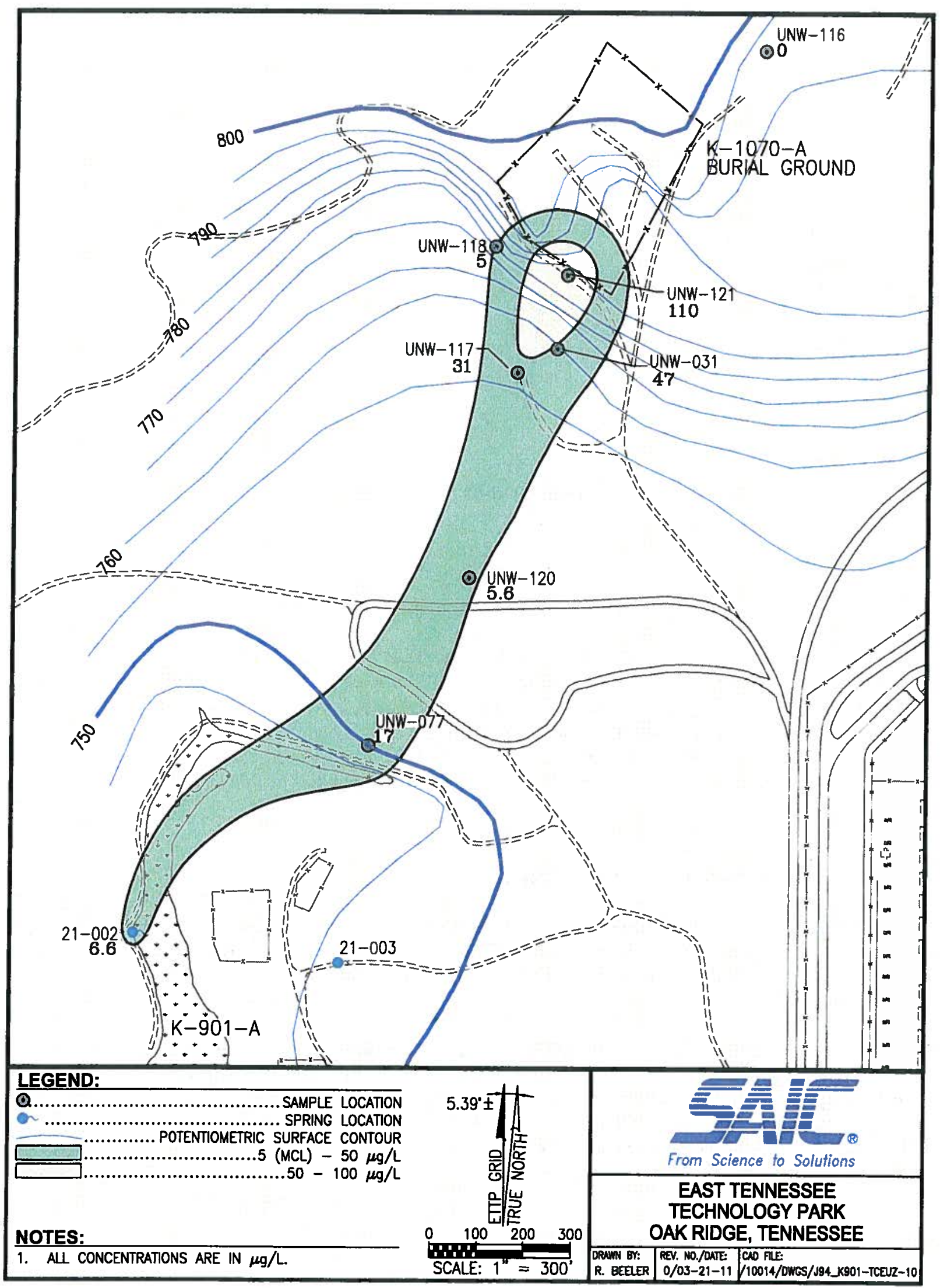

Fig. 11. Trichloroethene in unconsolidated groundwater in the K-901/K-1070-A Area, Feb./March 2010. 


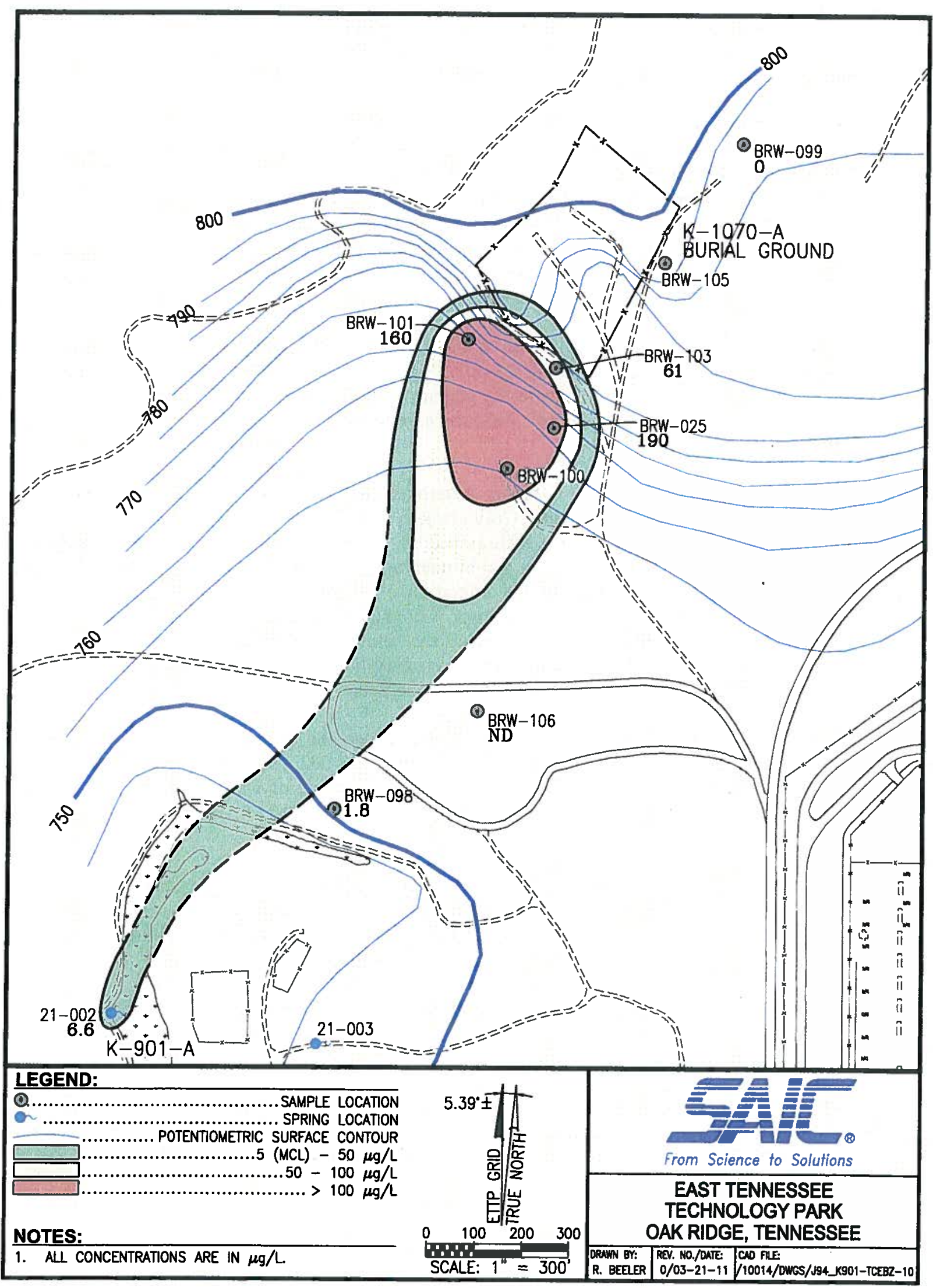

Fig. 12. Trichloroethene in bedrock groundwater in the K-901/K-1070-A Area, Feb./March 2010. 
All of the unconsolidated wells with concentrations greater than MCL are consistently showing a decreasing trend (see Figs. 13 and 14). All the bedrock wells with concentrations greater than MCL are showing either an increasing trend or a stable condition (see Figs. 15 through 17).

Two distinct plumes (see Figs. 11 and 12) with opposite plume behavior (i.e., one with decreasing trend and the other with either stable or increasing trend) exist at the K-1070-A Old Contaminated Burial Ground. The shallow plume (Fig. 11) originates at the K-1070-A Old Contaminated Burial Ground and extends downgradient to Spring 21-002. TCE concentration of this plume at the K-1070-A Burial Ground is decreasing and is predicted to be below the MCL within approximately 30 years from now by natural attenuation. However, TCE concentration of this plume near the Spring 21-002 (although slightly greater than MCL) is not expected to decrease unless TCE concentration in the bedrock decreases.

The bedrock plume is primarily located at the K-1070-A Old Contaminated Burial Ground with limited migration to downgradient Spring 21-002 (Fig. 12). However, this plume is either stable or increasing, and discharging contaminants to the unconsolidated zone at the downgradient locations (see Figs. 18 and 19). Fate and transport analysis indicates a period of greater than 100 years for attenuation of this plume to attain MCL.

Elements of the CSM include a highly heterogeneous groundwater system that includes an unconsolidated zone and a bedrock zone. Groundwater flow through the unconsolidated materials is significantly influenced by relict features such as bedding, fractures, and other structures. Groundwater preferentially follows numerous thin, cherty gravel intervals (relict bedding planes). These relict features provide a porous/permeable pathway for the migration of mobile contaminants, such as TCE, and a connection to the underlying bedrock." The bedrock is dominated by solution cavities that act as conduits for the rapid transport of groundwater. Also, where the solution cavities are interconnected along with fractures and bedding planes, they probably serve as primary flow paths for groundwater in bedrock. The groundwater migration direction is down dip and along the strike.

Fracture flow dominates the movement of groundwater and associated contaminants from the K-1070-A Old Contaminated Burial Ground to Spring 21-002. Spring 21-002, located in the wetlands area in the southern portion of the site, is a major source of water to the K-901-A Holding Pond and is the exit point for groundwater flowing beneath the K-1070-A Old Contaminated Burial Ground.

Flow paths in bedrock, where solution cavities form conduits for rapid transport of groundwater, are highly complex. Therefore, the location and depth of the contaminant plume between the burial ground and Spring 21-002 and other discharge points at the K-901-A Holding Pond are quite uncertain (Fig. 19).

There is probably a continuing secondary source present in the bedrock based on stable or increasing concentration trends and persistence in the environment even though the source had been removed in 2003 , and with no new activities at this site.

Contaminants are probably present in the bedrock matrix and are being dispersed back out into the fractures. Because the mass of contaminants present in the bedrock matrix is quite uncertain, the predicted monitored natural attenuation time for the bedrock plume has significant uncertainty. 


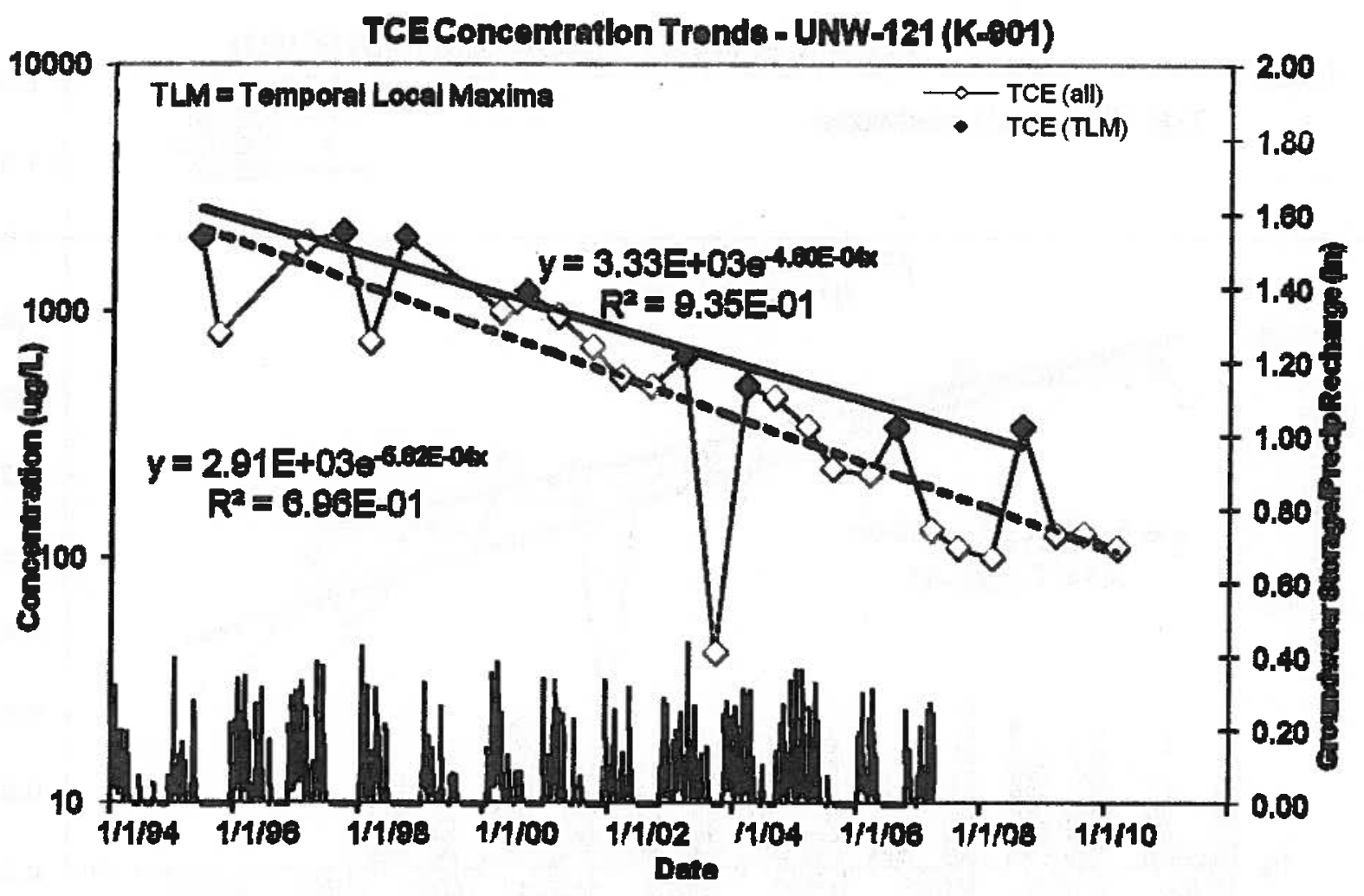

Fig. 13. Observed concentration trends in K-1070-A well UNW-121. 


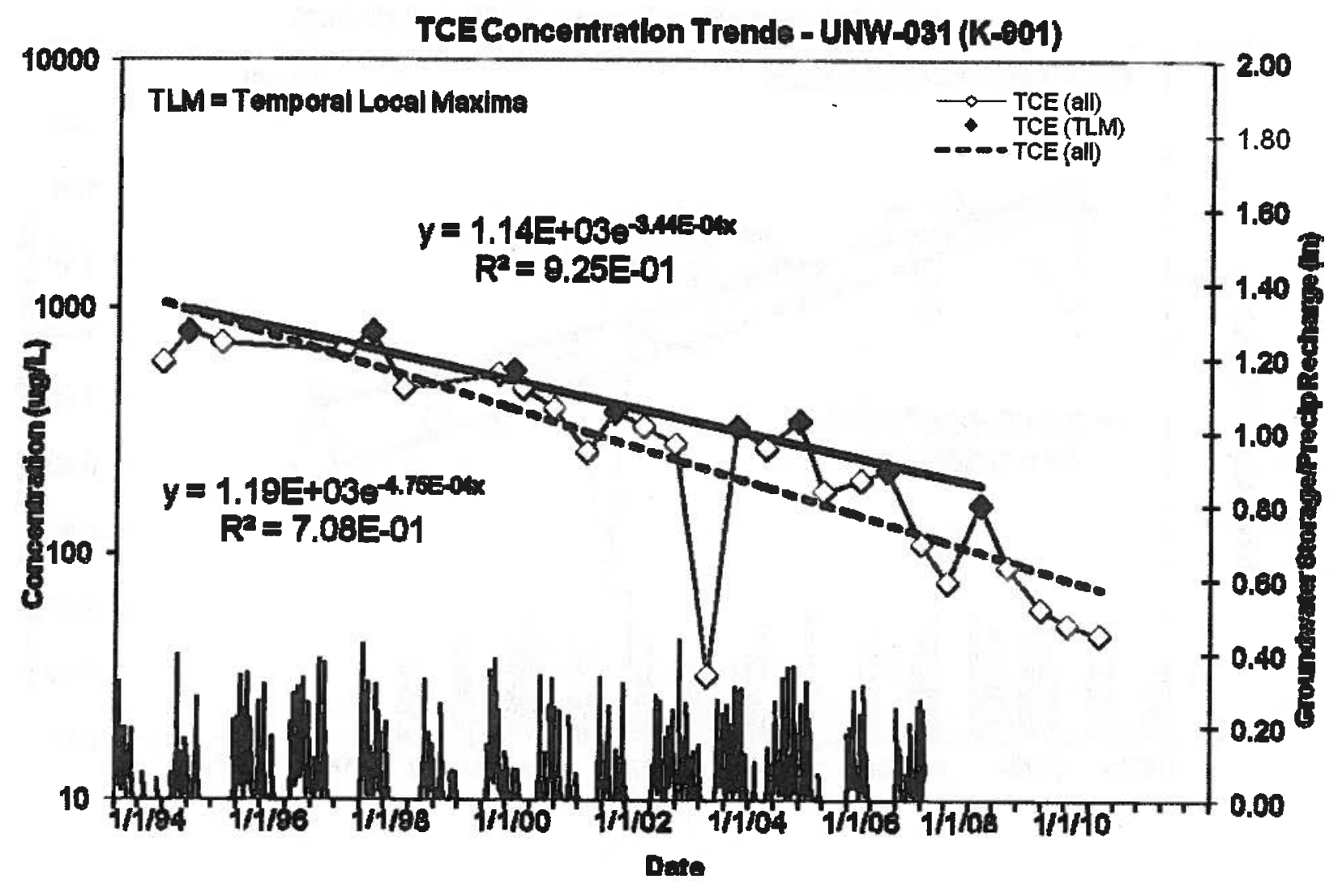

Fig. 14. Observed concentration trends at K-1070-A well UNW-031. 


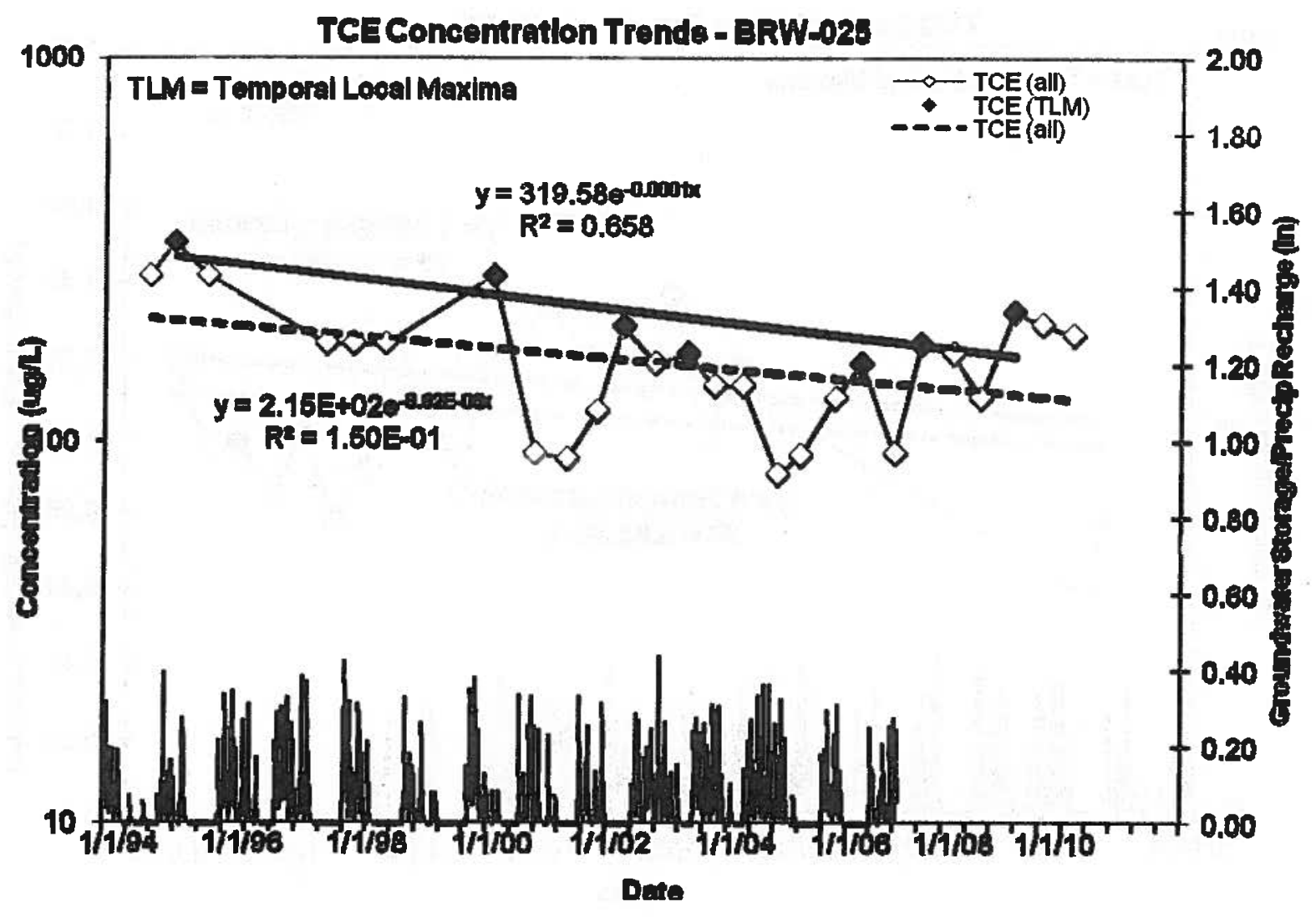

Fig. 15. Observed concentration trends at $\mathrm{K}-1070-\mathrm{A}$ well BRW-025. 


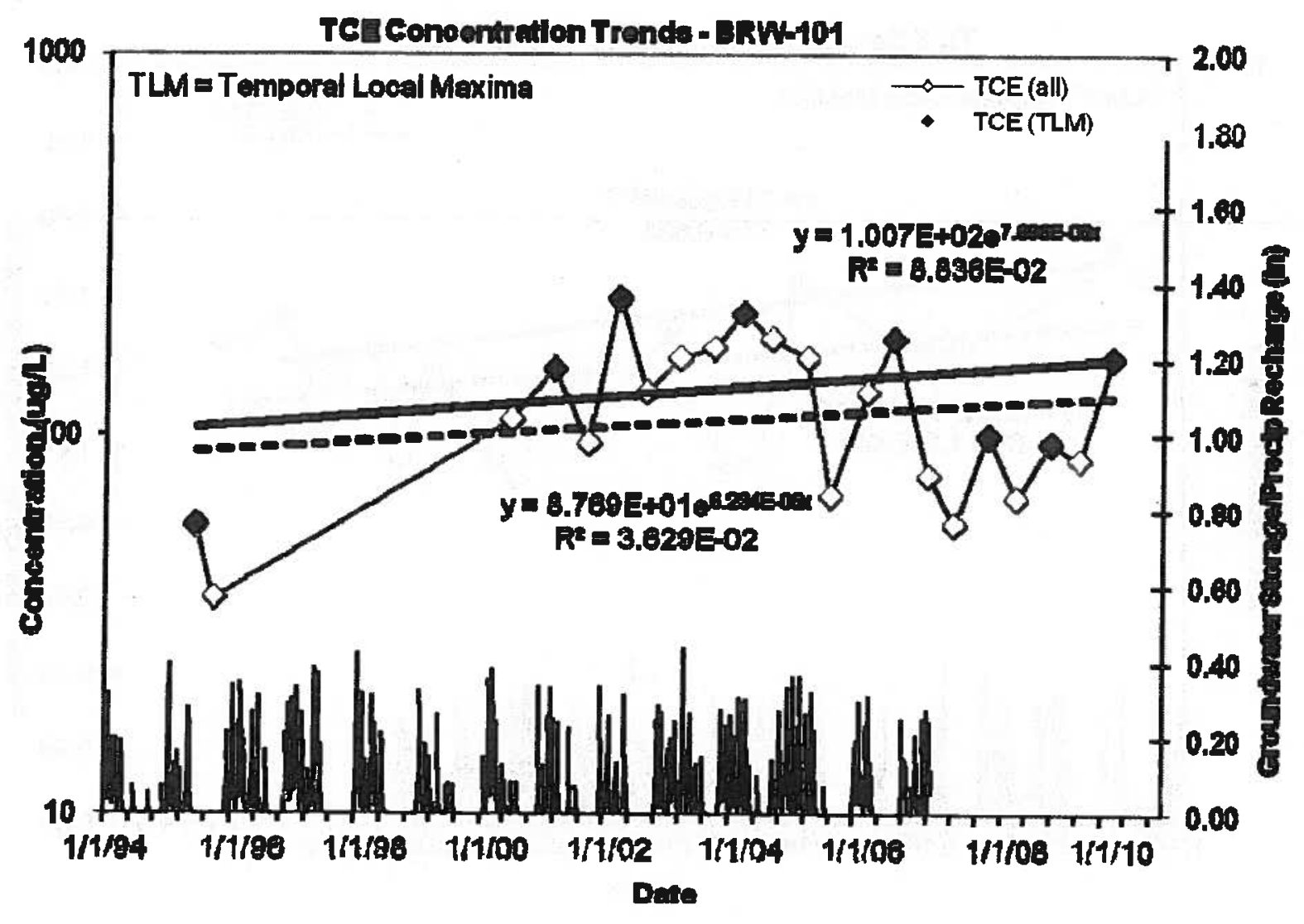

Fig. 16. Observed concentration trends at K-1070-A well BRW-101. 


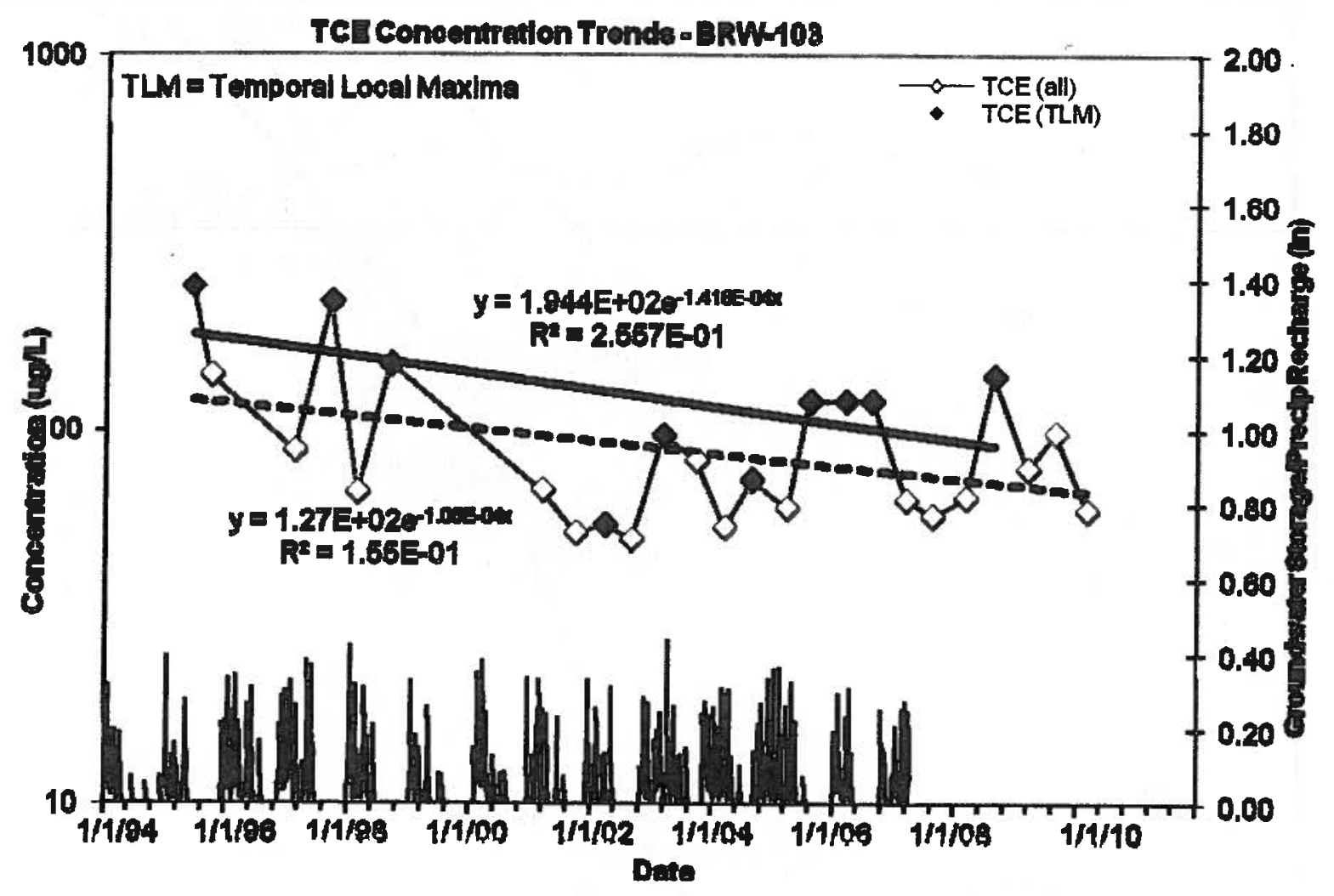

Fig. 17. Observed concentration trends at K-1070-A well BRW-103. 


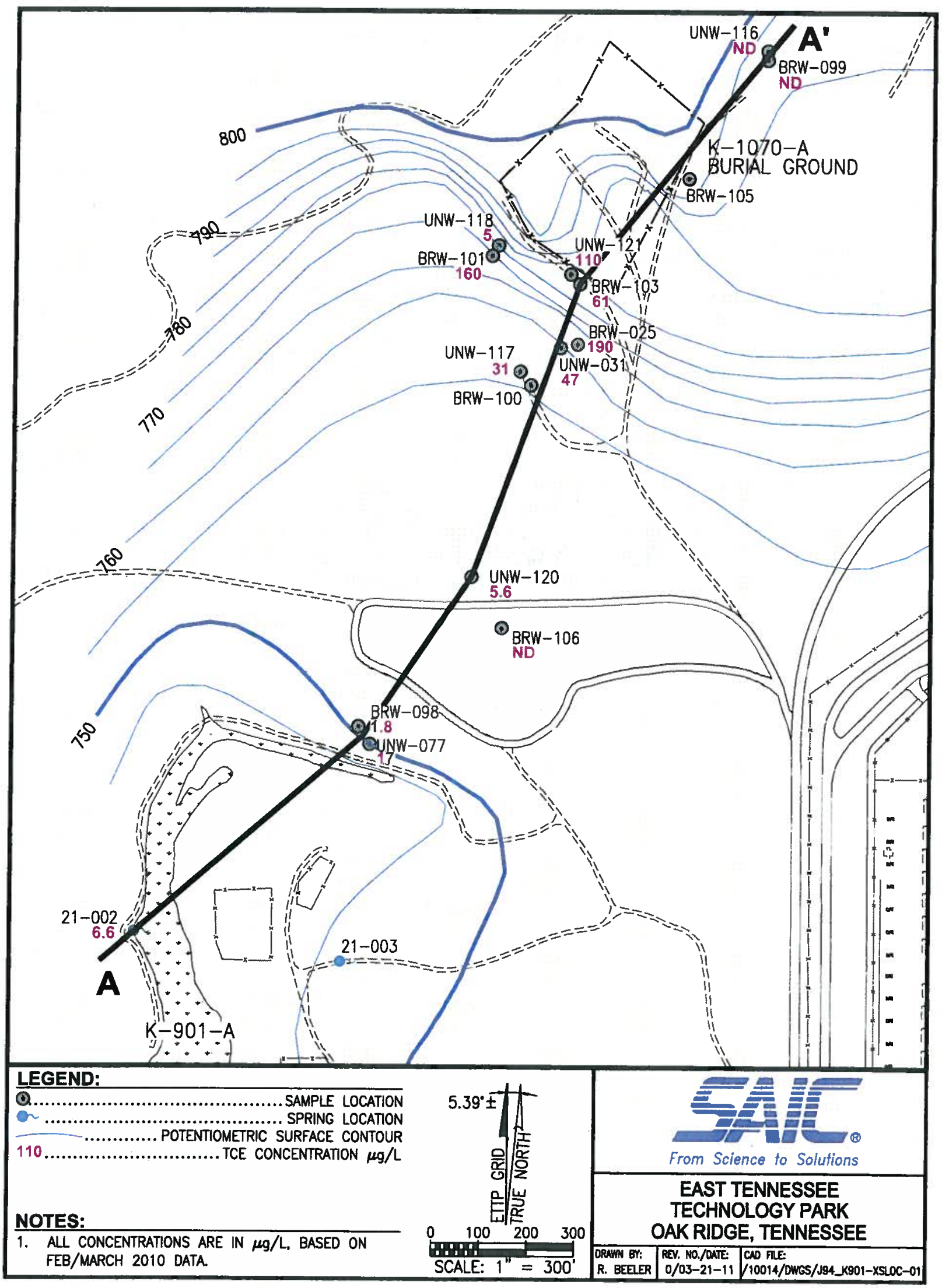

Fig. 18. Cross-section location in groundwater in the K-1070-A/K-901 Area at ETTP. 


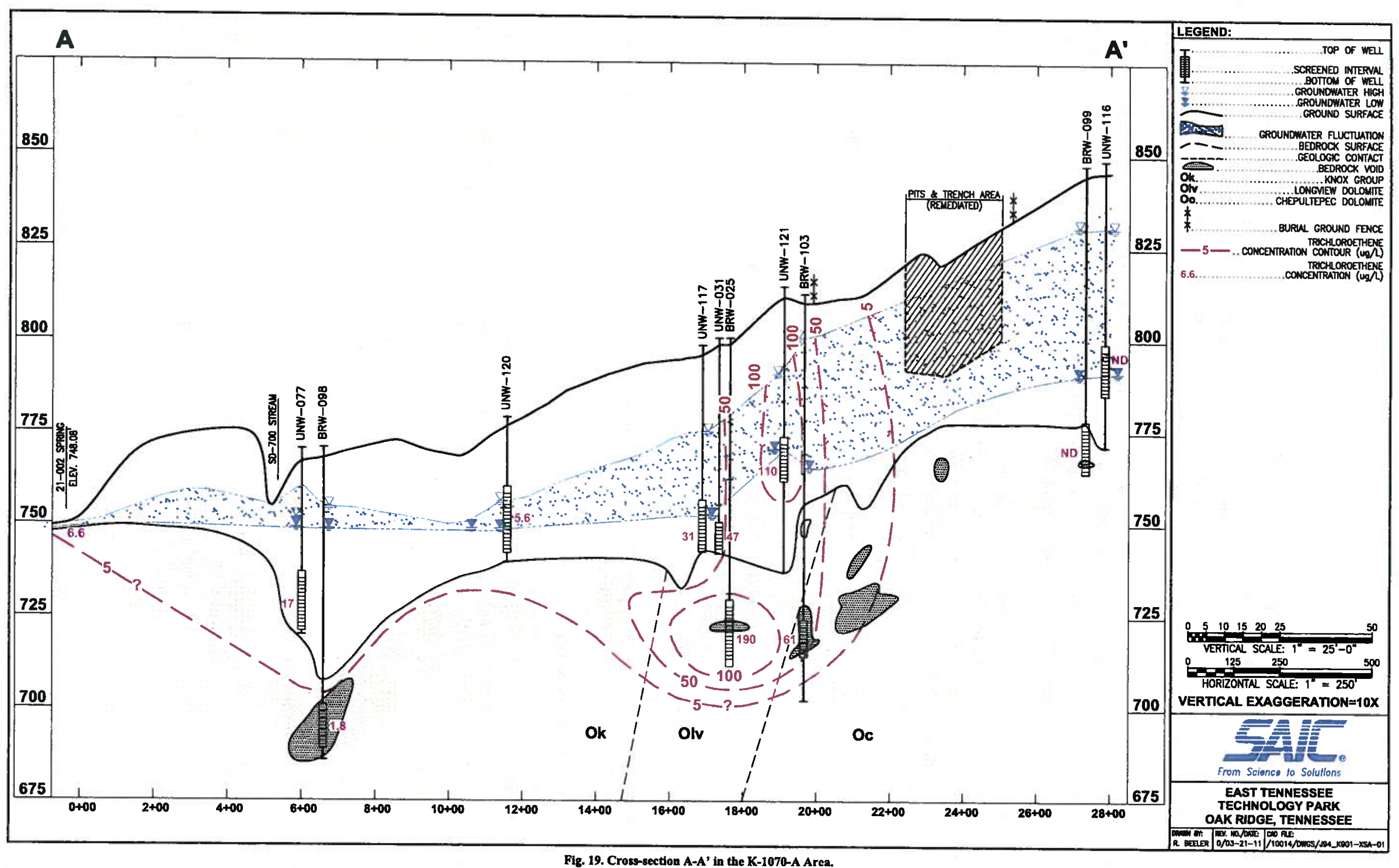




\subsubsection{Data Gaps}

VOCs continue to discharge via groundwater transport to the 21-002 spring and the K-901 Pond located south of the former K-1070-A Burial Ground. The selected alternative for groundwater at $\mathrm{K}-1070-\mathrm{A}$ in the Sitewide Remedial Investigation/Feasibility Study (RL/FS) [2007a] was monitored natural attenuation (MNA). However, recent data evaluations indicate that separate VOC plumes exist in the unconsolidated zone material and the bedrock downgradient of the burial ground. Although MNA remains as the appropriate alternative for the unconsolidated zone groundwater plume, concentration trends for contaminants in the bedrock plume indicate MNA may not be a viable option for this plume. Concentration trends for VOCs in bedrock wells downgradient of the former burial ground indicate a residual source continues to feed bedrock groundwater. Additional data collection and evaluation is necessary to determine the appropriate alternative for the bedrock plume at K-1070-A.

In addition, there are deficiencies in the current groundwater monitoring network at K-1070-A. Current VOC concentrations in groundwater below the footprint of the former burial ground are unknown. Also, the downgradient monitoring wells in the more distal portion of the bedrock and unconsolidated zone plumes do not appear to be located within the primary flow paths from the burial ground to the discharge points at the 21-002 spring and the K-901 Pond. Concentrations of TCE detected in some of the existing downgradient monitoring wells are less than the concentration observed at the 21-002 spring indicating these wells do not monitor the primary flow path. In addition, little is known about the extent of the plume in the area between the burial ground and the 21-002 spring.

\section{DATA COLLECTION ACTIVITIES}

\subsection{GROUNDWATER}

Additional groundwater quality data will be collected at the six areas of concern identified in Zone 1 . The proposed data collection at these areas is summarized below and in Table 5.

\subsubsection{K-720 Fly Ash Pile}

In order to determine current concentrations and trends in metals concentrations in the monitoring wells that have not been sampled in over 10 years in the vicinity of the K-720 Fly Ash Pile, groundwater samples will be collected from four existing monitoring wells (UNW-074, UNW-075, UNW-113, and BRW-089) located downgradient of the fly ash pile.

Samples collected from these wells will be analyzed for metals and anions, and field parameters will also be measured during sample collection. Both filtered and unfiltered samples will be collected. Sampling locations are indicated on Fig. 20.

\subsubsection{K-770 Scrap Yard}

In order to determine current concentrations at wells in the K-770 area that have not been sampled in over 10 years, the existing wells UNP-010, UNW-012, and UNW-014 (see Fig. 20) will be sampled and analyzed for metals and radiological parameters, including isotopic uranium and ${ }^{99} \mathrm{Tc}$. Both filtered and unfiltered samples will be collected. 
Table 5. Summary of the proposed sampling approach to address the Zone 1 groundwater data gaps

\begin{tabular}{|c|c|c|c|c|}
\hline Area & Locations to be sampled & Media & Analytical parameters ${ }^{\wedge}$ & Analytical methods \\
\hline K-720 Fly Ash Pile & $\begin{array}{l}\text { UNW-074 } \\
\text { UNW-075 } \\
\text { UNW-113 } \\
\text { BRW-089 }\end{array}$ & $\begin{array}{l}\text { GW } \\
\text { GW } \\
\text { GW } \\
\text { GW }\end{array}$ & $\begin{array}{l}\text { Metals - f and unf } \\
\text { Anions } \\
\text { Field measurements }\end{array}$ & $\begin{array}{c}\text { SW846-6010B and SW846-7470 } \\
\text { EPA-300.0, EPA-353.2, SM2320B, } \\
\text { and SM4500-F-C }\end{array}$ \\
\hline K-770 Scrap yard & $\begin{array}{l}\text { UNP-010 } \\
\text { UNW-012 } \\
\text { UNW-014 }\end{array}$ & $\begin{array}{l}\text { GW } \\
\text { GW } \\
\text { GW }\end{array}$ & $\begin{array}{l}\text { Metals }-f \text { and unf } \\
\text { Field measurements } \\
\text { Radiological }^{d}-f \& \text { unf }\end{array}$ & $\begin{array}{l}\text { SW846-6010B and SW846-7470 } \\
\text { EPA-900, EPA-900.1, EPA-907.0 } \\
\text { and liquid scintillation }\end{array}$ \\
\hline Duct Island/K-1070-F & PCO Spring & SW & $\begin{array}{c}\text { VOCs } \\
\text { Metals } \\
\text { Radiological }^{d}\end{array}$ & $\begin{array}{c}\text { SW846-8260B } \\
\text { SW846-6010B and SW846-7470 } \\
\text { EPA-900, EPA-900.1, EPA-907.0 } \\
\text { and liquid scintillation }\end{array}$ \\
\hline Contractor's Spoil Area & $\begin{array}{l}\text { Spring } 10-895 \\
\text { North landfill toe stream }\end{array}$ & $\begin{array}{l}\text { SW } \\
\text { SW }\end{array}$ & $\begin{array}{c}\text { VOCs } \\
\text { Metals } \\
\text { Radiological }^{d}\end{array}$ & $\begin{array}{c}\text { SW846-8260B } \\
\text { SW846-6010B and SW846-7470 } \\
\text { EPA-900, EPA-900.1, EPA-907.0 } \\
\text { and liquid scintillation }\end{array}$ \\
\hline K-1085 Firehouse Burn Area & $\begin{array}{c}\text { UNP-006 } \\
\text { UNP-011 } \\
\text { UNW-033 } \\
\text { UNW-034 } \\
\text { UNW-035 } \\
\text { Spring } 247 \\
\text { Cloverleaf drainage } \\
\text { Future: } 4 \text { new wells }\end{array}$ & $\begin{array}{l}\text { GW } \\
\text { GW } \\
\text { GW } \\
\text { GW } \\
\text { GW } \\
\text { SW } \\
\text { SW } \\
\\
\text { GW }\end{array}$ & $\begin{array}{c}\text { VOCs } \\
\text { Metals }- \text { f and unf } \\
\text { Field measurements }\end{array}$ & $\begin{array}{c}\text { SW846-8260B } \\
\text { SW846-6010B and SW846-7470 }\end{array}$ \\
\hline K-1070-A Burial Ground & $\begin{array}{c}\text { UNW-031 } \\
\text { UNW-077 } \\
\text { UNW-116 } \\
\\
\text { UNW-117 } \\
\text { UNW-118 } \\
\text { UNW-119 } \\
\text { UNW-120 } \\
\text { UNW-121 } \\
\text { BRW-025 } \\
\text { BRW-098 } \\
\text { BRW-099 } \\
\text { BRW-100 } \\
\text { BRW-101 } \\
\text { BRW-103 } \\
\text { BRW-105 } \\
\text { BRW-106 } \\
\text { Spring 21-002 }\end{array}$ & $\begin{array}{l}\text { GW } \\
\text { GW } \\
\text { GW } \\
\\
\text { GW } \\
\text { GW } \\
\text { GW } \\
\text { GW } \\
\text { GW } \\
\text { GW } \\
\text { GW } \\
\text { GW } \\
\text { GW } \\
\text { GW } \\
\text { GW } \\
\text { GW } \\
\text { GW } \\
\text { SW }\end{array}$ & $\begin{array}{c}\text { VOCs } \\
\text { Field measurements } \\
\text { Radiological }^{d}-f \text { and unf }\end{array}$ & $\begin{array}{c}\text { SW846-8260B } \\
\text { EPA-900, EPA-900.1, EPA-907.0 } \\
\text { and liquid scintillation }\end{array}$ \\
\hline & $\begin{array}{l}\text { Future: } 6 \text { new wells } \\
\text { Borehole for unconsolidated } \\
\text { zone well in former burial } \\
\text { ground }\end{array}$ & $\begin{array}{l}\text { GW } \\
\text { Soil }\end{array}$ & $\begin{array}{c}\text { VOCs } \\
\text { Radiological }^{d}\end{array}$ & $\begin{array}{c}\text { SW846-8260B } \\
\text { EPA-900, EPA-900.1, EPA-907.0 } \\
\text { and liquid scintillation }\end{array}$ \\
\hline
\end{tabular}

${ }^{a}$ Analytical parameters are for all locations within that area.

${ }^{b}$ Anions include: bicarbonate, carbonate, chloride, fluoride, nitrate/nitrite, and sulfate.

' Field measurements include: temperature, $\mathrm{pH}$, dissolved oxygen, turbidity, specific conductance, and oxidation-reduction potential.

${ }^{d}$ Radiological parameters include: uranium isotopes, thorium isotopes, ${ }^{137} \mathrm{Cs},{ }^{60} \mathrm{Co},{ }^{40} \mathrm{~K}$, and ${ }^{99} \mathrm{Tc}$.

BRW = bedrock well.

$\mathrm{EPA}=$ U. S. Environmental Protection Agency.

$\mathrm{GW}=$ groundwater.

$\mathrm{f}=$ filtered.

unf $=$ unfiltered. 


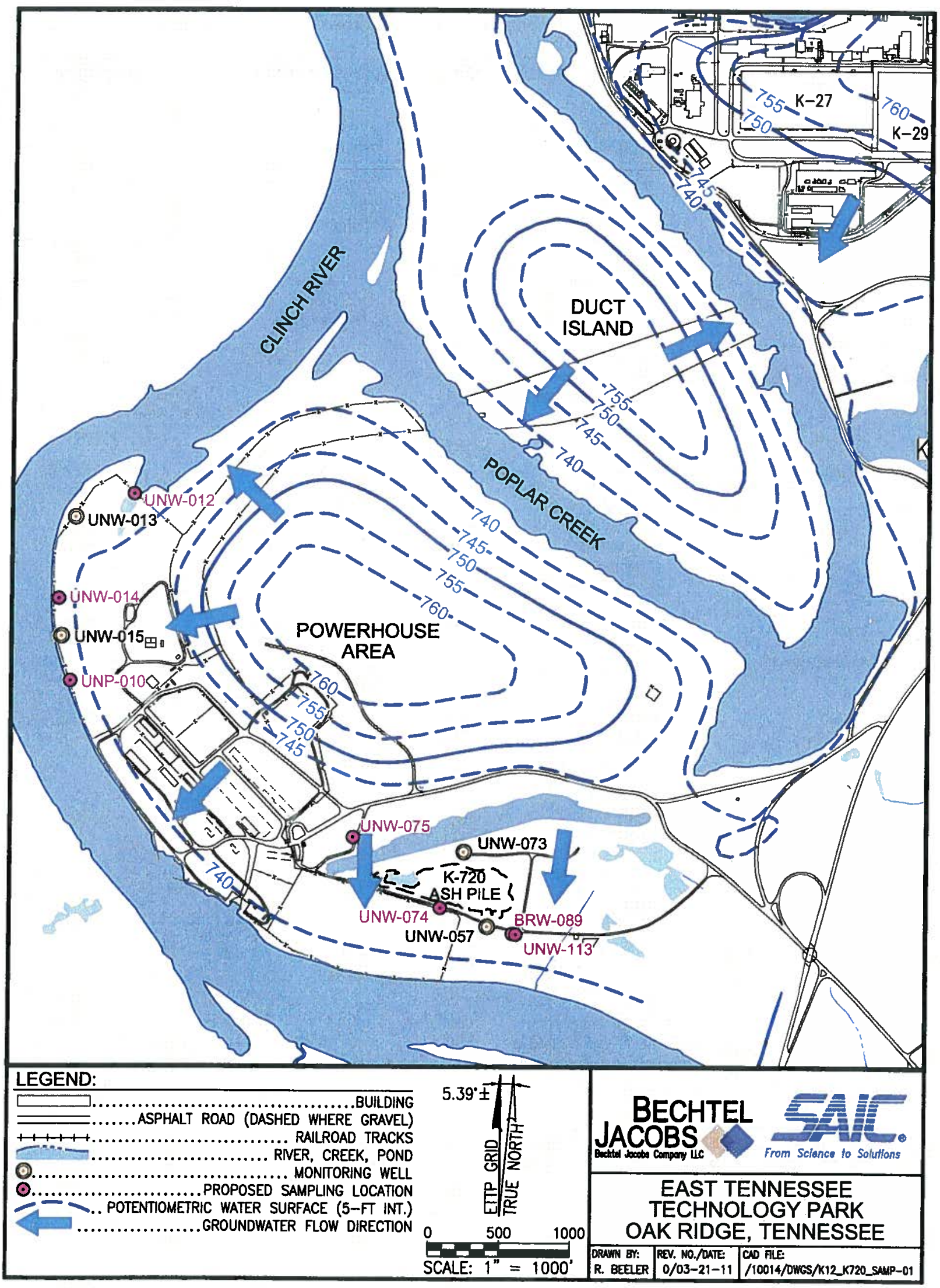

Fig. 20. K-720 Fly Ash and K-770 Scrap Yard proposed sampling locations. 


\subsubsection{Duct Island}

In order to determine if the decreasing trend in TCE concentration at the spring is continuing, monitoring of the PCO Spring (Fig. 21) will be conducted during the periods of the year that the spring is accessible (low pool conditions). Samples collected from the spring will be analyzed for VOCs, metals, and radiological parameters including uranium isotopes and ${ }^{99} \mathrm{Tc}$.

\subsubsection{K-1085 Firehouse Burn/J.A. Jones Maintenance Area}

Due to the uncertainty in the extent of known groundwater contamination in the K-1085 Firehouse Burn/J.A. Jones Maintenance Area, additional monitoring wells will be installed. The new monitoring wells will consist of a total of four new monitoring wells that will be installed consisting of one well completed in bedrock and three wells completed in the unconsolidated zone above bedrock. The locations of the new monitoring wells are indicated in Fig. 22.

In addition to groundwater samples collected from the four new monitoring wells, the existing five monitoring wells and piezometers will also be sampled to determine the accuracy of the 2009 sample collected from well UNW-033 and to determine current concentrations at all of the wells. Surface water samples will also be collected from two locations in the K-1085 area. Spring 247 will be sampled when discharge is occurring at this spring. A surface water sample will also be collected from the drainage swale south of the Firehouse Burn Area within the cloverleaf of the access ramp to Highway 58. Sampling locations for both groundwater and surface water at the K-1085 Firehouse Burn/J.A. Jones Maintenance Area are indicated on Fig. 22. Samples collected from these locations will be analyzed for VOCs and metals. Both filtered and unfiltered metals samples will be collected.

\subsubsection{Contractor's Spoil Area}

To help determine if the CSA is the potential source for the TCE present at Spring 10-895, a surface water sample will be collected from the intermittent drainage at the toe of the slope of the CSA to determine if VOCs are being transported via shallow groundwater to this likely surface water discharge point. In addition, Spring 10-895 will be sampled to verify current TCE concentrations and trends. The samples collected from 10-895 and the intermittent stream will be analyzed for VOCs, metals, and radiological parameters, including ${ }^{99} \mathrm{Tc}$. Sampling locations are indicated on Fig. 23.

\subsubsection{Former K-1070-A Burial Ground}

In order to determine current contaminant concentrations in groundwater beneath the footprint of the former burial ground and improve the understanding of the extent of the plume downgradient of the former burial ground, three monitoring well pairs, consisting of a bedrock well and an unconsolidated zone well, will be installed at the three locations indicated in Fig. 24. This includes one well pair within the footprint of the former burial ground, and one well pair each at two downgradient locations along the suspected flow path from the burial ground to the 21-002 spring. Samples will be collected from these six new wells and the existing well network and analyzed for VOCs and radiological parameters.

In addition, because native soils remain in the interval below the bottom of the clean soil used for filling the burial ground excavation and above the top of bedrock, soil samples will be collected from the borehole drilled for the unconsolidated zone monitoring well in the footprint of the former burial ground from beneath the clean fill material down to bedrock. Soil samples will be analyzed for VOCs and radiological parameters. 


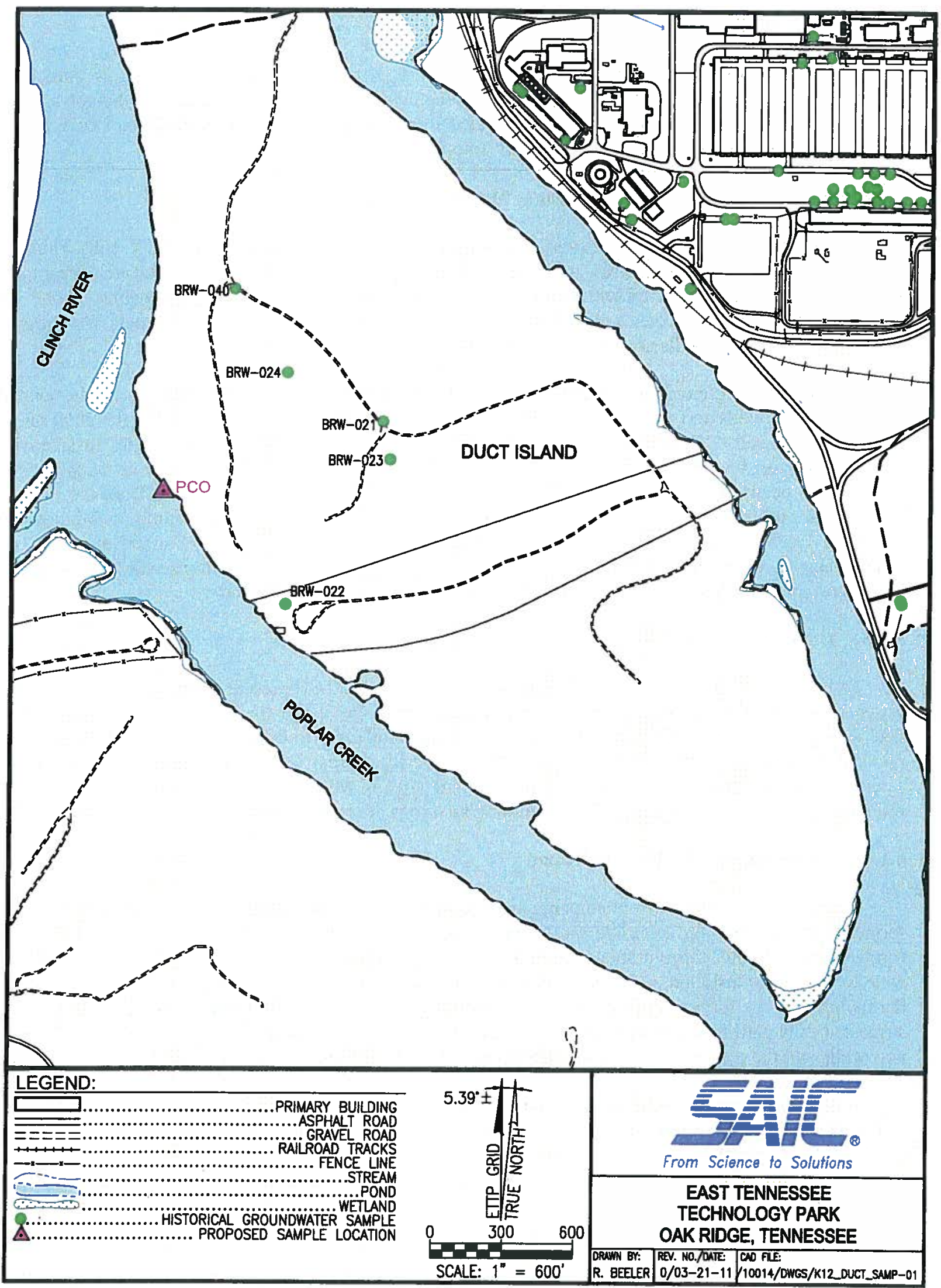

Fig. 21. Proposed sample locations on Duct Island. 


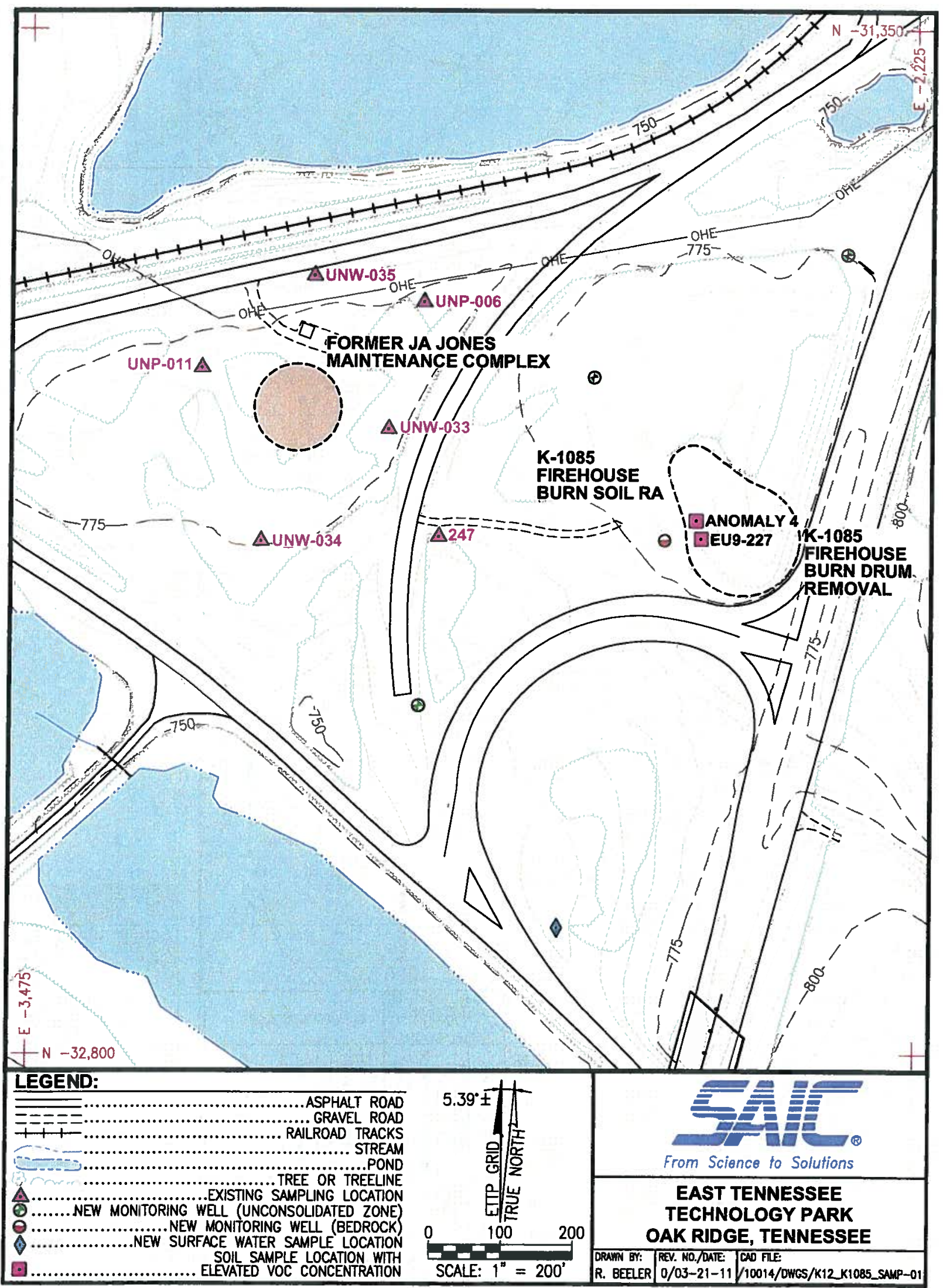

Fig. 22. Proposed sampling locations at the K-1085 Old Firehouse Burn/J. A. Jones Maintenance Areas. 


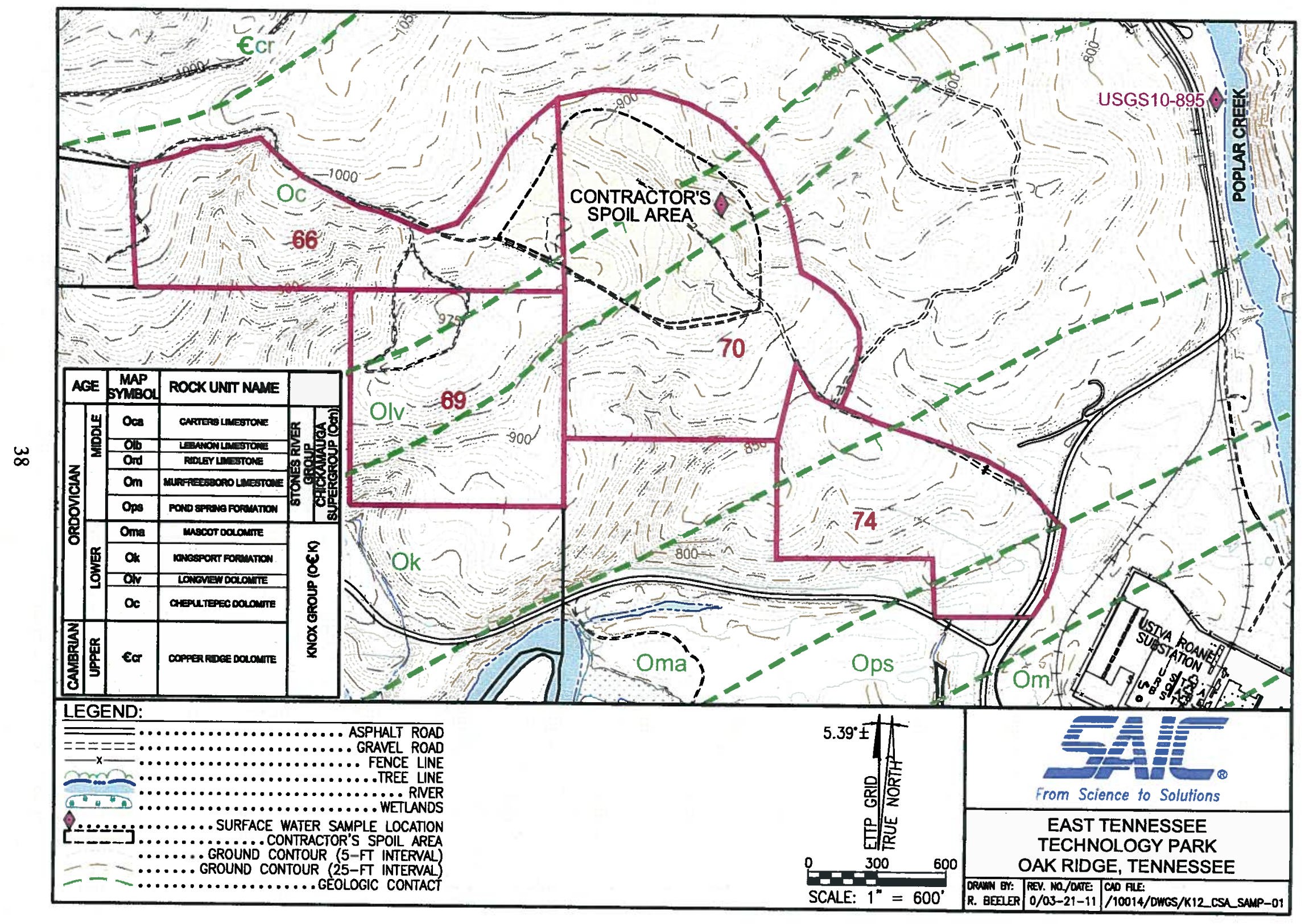

Fig. 23. Contractor's Spoil Area proposed sample locations. 


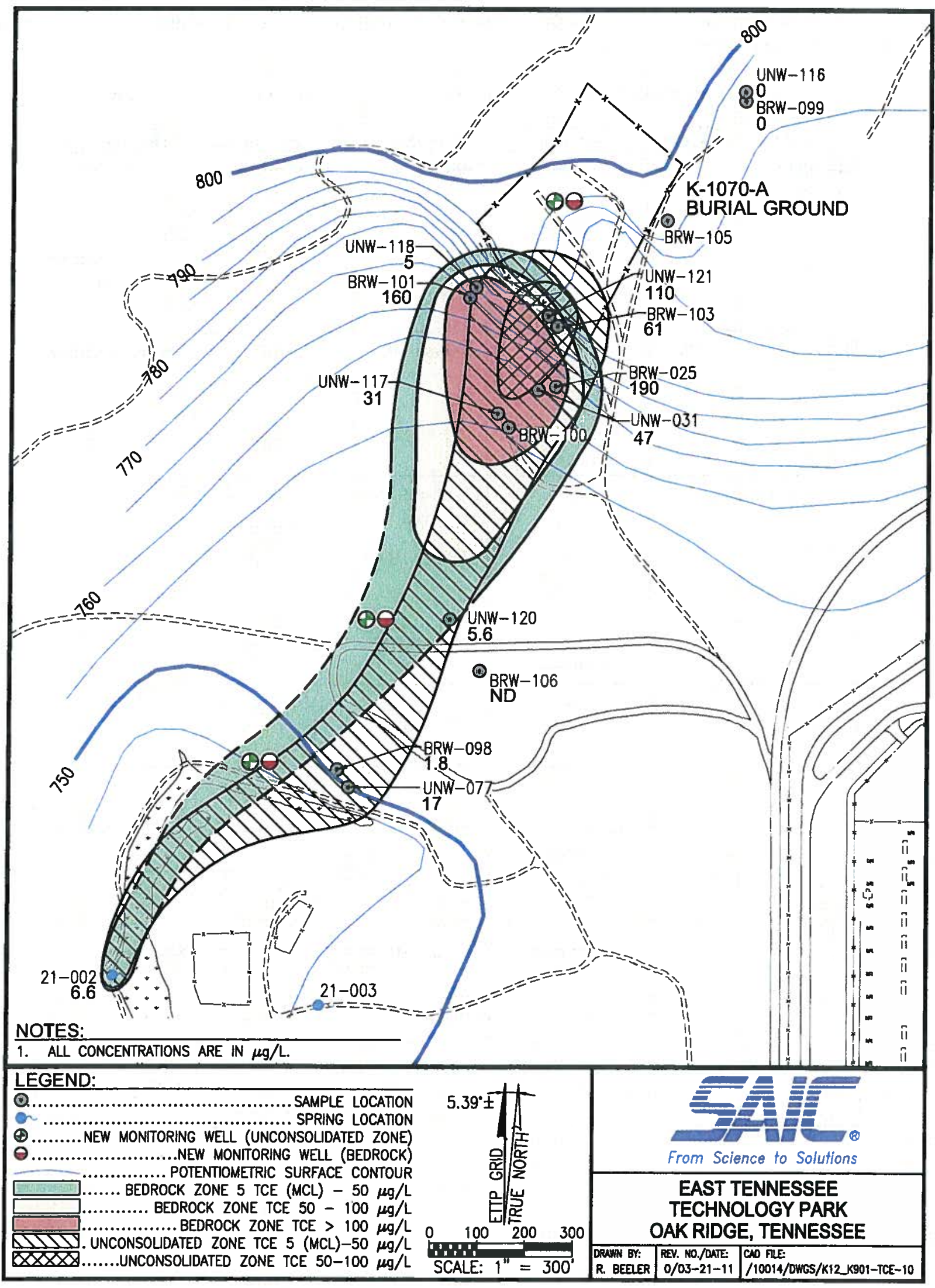

Fig. 24. Proposed well locations at the former K-1070-A Burial Ground. 
The container, preservation and holding time requirements for the proposed Zone 1 groundwater data gap samples are presented in Table 6.

Table 6. Container, preservation, and holding time requirements for Zone 1 samples

\begin{tabular}{|c|c|c|c|c|c|}
\hline Area & Media & Analyte & Container & Preservation & Holding time \\
\hline $\begin{array}{l}\text { K-720 Fly } \\
\text { Ash Pile }\end{array}$ & GW & $\begin{array}{c}\text { Metals }^{a} \\
\text { Anions }^{b} \\
\text { Field parameters } \\
\end{array}$ & $\begin{array}{l}\text { 500-mL HDPE } \\
\text { 1-L HDPE } \\
\text { NA }\end{array}$ & $\begin{array}{c}\mathrm{HNO}^{3} \text { to } \mathrm{pH}<2 \\
\text { Cool to } 4^{\circ} \mathrm{C} \\
\text { Cool to } 4^{\circ} \mathrm{C} \\
\text { NA }\end{array}$ & $\begin{array}{l}6 \text { months } \\
28 \text { days; } 48 \text { hrs for } \\
\text { nitrate, nitrite, and } \\
\text { phosphate } \\
\text { NA }\end{array}$ \\
\hline $\begin{array}{l}\text { K-770 Scrap } \\
\text { Yard }\end{array}$ & GW & $\begin{array}{c}\text { Metals } \\
\text { Radiological } \\
\text { parameters }^{d}\end{array}$ & $\begin{array}{l}\text { 500-mL HDPE } \\
\text { 2 2-L HDPE }\end{array}$ & $\begin{array}{l}\mathrm{HNO}^{3} \text { to } \mathrm{pH}<2 \\
\text { Cool to } 4^{\circ} \mathrm{C} \\
\text { Cool to } 4^{\circ} \mathrm{C}\end{array}$ & $\begin{array}{c}6 \text { months; } 28 \text { days } \\
\text { for } \\
\mathrm{Hg} \\
6 \text { months }\end{array}$ \\
\hline Duct Island & sW & $\begin{array}{c}\text { VOCs } \\
\text { Metals } \\
\text { Radiological } \\
\text { parameters }\end{array}$ & $\begin{array}{c}\text { (3) } \begin{array}{c}40-\mathrm{mL} \text { glass } \\
\text { vial }\end{array} \\
\text { 500-mL HDPE } \\
\text { 2 2-L HDPE }\end{array}$ & $\begin{array}{c}\mathrm{HCl} \text { to } \mathrm{pH}<2 \\
\mathrm{Cool} \text { to } 4^{\circ} \mathrm{C} \\
\mathrm{HNO}^{3} \text { to } \mathrm{pH}<2 \\
\text { Cool to } 4^{\circ} \mathrm{C} \\
\text { Cool to } 4^{\circ} \mathrm{C}\end{array}$ & $\begin{array}{c}14 \text { days } \\
6 \text { months; } 28 \text { days } \\
\text { for } \\
\mathrm{Hg} \\
6 \text { months }\end{array}$ \\
\hline $\begin{array}{l}\text { Contractor's } \\
\text { Spoil Area }\end{array}$ & SW & $\begin{array}{c}\text { VOCs } \\
\text { Metals } \\
\text { Radiological } \\
\text { parameters }\end{array}$ & $\begin{array}{c}\text { (3) } \begin{array}{c}40-\mathrm{mL} \text { glass } \\
\text { vial }\end{array} \\
\text { 500-mL HDPE } \\
\text { 2 2-L HDPE }\end{array}$ & $\begin{array}{c}\mathrm{HCl} \text { to } \mathrm{pH}<2 \\
\text { Cool to } 4^{\circ} \mathrm{C} \\
\mathrm{HNO}^{3} \text { to } \mathrm{pH}<2 \\
\mathrm{Cool} \text { to } 4^{\circ} \mathrm{C} \\
\text { Cool to } 4^{\circ} \mathrm{C}\end{array}$ & $\begin{array}{c}14 \text { days } \\
6 \text { months; } 28 \text { days } \\
\text { for } \mathrm{Hg} \\
6 \text { months }\end{array}$ \\
\hline $\begin{array}{l}\text { K-1085 } \\
\text { Firehouse } \\
\text { Burn/J.A. } \\
\text { Jones Area }\end{array}$ & GW & $\begin{array}{l}\text { VOCs } \\
\text { Metals }\end{array}$ & $\begin{array}{c}\text { (3) } 40-\mathrm{mL} \text { glass } \\
\text { vial } \\
\text { 500-mL HDPE }\end{array}$ & $\begin{array}{c}\mathrm{HCl} \text { to } \mathrm{pH}<2 \\
\mathrm{Cool} \text { to } 4^{\circ} \mathrm{C} \\
\mathrm{HNO}^{3} \text { to } \mathrm{pH}<2 \\
\text { Cool to } 4^{\circ} \mathrm{C}\end{array}$ & $\begin{array}{c}14 \text { days } \\
6 \text { months; } 28 \text { days } \\
\text { for } \mathrm{Hg}\end{array}$ \\
\hline & SW & $\begin{array}{l}\text { VOCs } \\
\text { Metals }\end{array}$ & $\begin{array}{c}\text { (3) } \begin{array}{c}40-\mathrm{mL} \text { glass } \\
\text { vial }\end{array} \\
\text { 500-mL HDPE }\end{array} \mid$ & $\begin{array}{c}\mathrm{HCl} \text { to } \mathrm{pH}<2 \\
\mathrm{Cool} \text { to } 4^{\circ} \mathrm{C} \\
\mathrm{HNO}^{3} \text { to } \mathrm{pH}<2 \\
\text { Cool to } 4^{\circ} \mathrm{C}\end{array}$ & $\begin{array}{c}14 \text { days } \\
6 \text { months; } 28 \text { days } \\
\text { for } \mathrm{Hg}\end{array}$ \\
\hline
\end{tabular}


Table 6. Container, preservation, and holding time requirements for Zone 1 samples

(Continued)

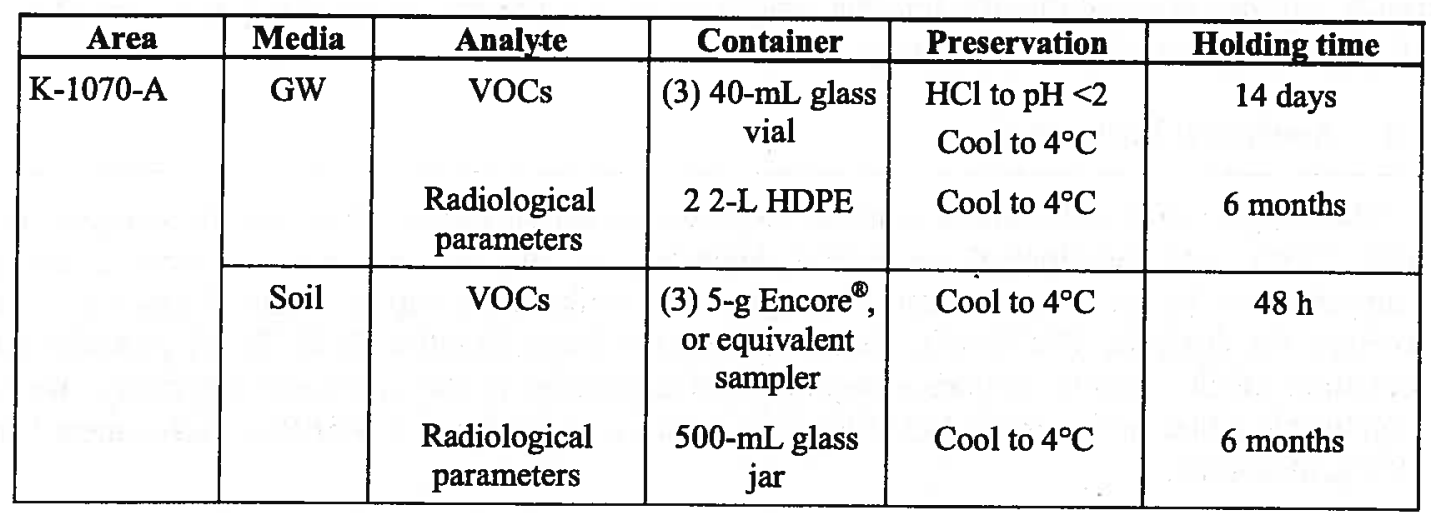

${ }^{a}$ Metals to be analyzed include: aluminum, antimony, arsenic, barium, beryllium, boron, cadmium, calcium, chromium, cobalt, copper, iron, lead, lithium, magnesium, manganese, mercury, nickel, potassium, selenium, silicon, silver, sodium, strontium, thallium, vanadium, and zinc.

${ }^{b}$ Anions include: bicarbonate, carbonate, chloride, fluoride, nitrate, and sulfate.

${ }^{c}$ Field parameters include: temperature, dissolved oxygen, turbidity, $\mathrm{pH}$, specific conductance, and oxidationreduction potential.

${ }^{d}$ Radiological parameters include: gross alpha, gross beta, ${ }^{137} \mathrm{Cs},{ }^{60} \mathrm{Co},{ }^{40} \mathrm{~K},{ }^{99} \mathrm{Tc},{ }^{228 / 230 / 232} \mathrm{Th}$, and ${ }^{233 / 234 / 235 / 236 / 238} \mathrm{U}$

$\mathrm{g}=$ gram. $\quad \mathrm{NA}=$ not applicable.

GW = groundwater. $\quad$ SW $=$ surface water.

HDPE = high-density polyethylene bottle. $\quad$ VOC $=$ volatile organic compound.

$\mathrm{mL}=$ milliliter.

\subsubsection{Groundwater Sample Collection Method}

\subsubsection{Sampling of wells}

Groundwater samples to be collected from existing and proposed monitoring wells will be collected in accordance with methods and procedures consistent with those used by the current EWQP.

Collection of groundwater samples from monitoring wells will be accomplished in three general steps: (1) measurement of field parameters, (2) well purging, and (3) groundwater sample collection. Purging and sampling of monitoring wells will be conducted using a decontaminated, nondedicated, low-flow, downhole pump or similar equipment. The inlet of the sampling pump will be placed at the midpoint of the screened interval. This level will be adjusted for wells at which the static water level is within the well screen. Before installation of the sampling pump, the static water level will be recorded. Purging and sampling activities may not begin until either the static water level returns to within $10 \%$ of the initial static water level or $12 \mathrm{~h}$ have passed since installation of the pump, whichever occurs first.

Micropurging techniques will be employed in all wells to minimize the volume of purge water, disturbance of the aquifer, and disturbance of the samples. The field parameters of $\mathrm{pH}$, conductivity, temperature, dissolved oxygen, oxidation-reduction potential, and turbidity will be monitored during micropurging. The purge rate will be adjusted, as necessary, to avoid purging any well to dryness and to equal the recharge of the aquifer. Purging will be considered complete when the field parameters stabilize within plus or minus $10 \%$ after a minimum of three readings at 5 -min intervals.

Sampling of the monitoring well will begin immediately after completion of purging. The groundwater sample volume initially obtained will be used for laboratory chemical analysis. All groundwater samples 
will be transferred directly into laboratory sample containers from the sampler. Sample containers designated for VOC analysis will be filled so that no headspace is present in the containers. Groundwater samples will be collected directly into the sample container, pre-preserved, if required, and placed on ice in a cooler for delivery to the laboratory.

\subsubsection{Analytical Parameters}

The samples collected from the existing and new monitoring well locations will be analyzed for metals, anions, VOCs, and radiological parameters depending on the area of concern. Table 5 indicates the parameters to be analyzed for the various samples to be collected. Samples will be shipped to a fixed-base laboratory for analysis. The Quality Assurance Project Plan (QAPP) [DOE 2004] provides additional information on the quality assurance requirements applicable to the analytical laboratory. Revisions to the applicable tables in the original QAPP are included in Appendix A to this Risk Assessment Work Plan (RIWP) Addendum.

\subsubsection{Quality Control Duplicate Samples}

During the sampling of groundwater from the monitoring wells, quality control (QC) duplicates will be collected along with the regular groundwater samples. The monitoring well locations selected for duplicate sampling will be based on a review of historical information indicating which wells have shown elevated concentrations of COCs. The exact number of duplicate samples will depend on the total number of groundwater samples collected for the project. However, the total number will be at least $10 \%$ of the entire sample population. The QC duplicates will be analyzed for the same analytes as in the original sample.

\subsubsection{QC rinsate blank samples}

During the decontamination of sampling equipment used for groundwater purging and collection, QC rinsate blanks will be collected from all nondedicated and nondisposable sample collection equipment used to obtain groundwater samples from groundwater monitoring wells. The total number of rinsate blanks to be collected from the monitoring wells will represent approximately $5 \%$ of the entire sample population. These samples will be collected on a regular basis throughout the implementation of investigation activities. The QC rinsate blanks will be analyzed for the same suite of analytes as the original samples.

\subsubsection{QC trip blank samples}

QC trip blanks consisting of sealed containers of American Society for Testing and Materials (ASTM) Type II or equivalent water will be used for the project. One trip blank will be placed into each cooler used to store portions of groundwater samples designated for VOC analysis. These blanks will remain with the sample containers until groundwater sampling is completed and the samples are shipped to the off-site laboratory for chemical analysis.

\subsubsection{Monitoring Well Drilling and Installation}

\subsubsection{Drilling methods and equipment}

The air-rotary drilling method or reverse circulation method will be used for the drilling of boreholes for installation of bedrock monitoring wells. The boreholes for groundwater monitoring well installation will have an approximate 14-in.-diameter borehole for installation of the surface casing and a minimum 8 -in. borehole for installation of the well casing. Surface casings will be a minimum of $8-5 / 8$-in. outside diameter carbon steel and pressure-grouted in place. 
Boreholes for installation of unconsolidated zone wells and collection of soil samples will be installed using the hollow-stem-auger drilling method. All auger-drilled soil boreholes will be advanced using 6.625-in.-inside-diameter hollow-stem augers. These augers will be used because they are of sufficient diameter to accommodate the thin-wall samplers needed for sample collection and construction of 4-in. monitoring wells within the boreholes.

\section{Well casing and screen}

The well casing materials used for construction of monitoring wells will be composed of new, precleaned, 4-in. stainless steel. Casing sections will be flush-threaded. Gaskets, pop rivets, and screws will not be used during monitoring well construction. Stainless steel centralizers will be attached within $10 \mathrm{ft}$ of the top of the screen and every $20 \mathrm{ft}$ thereafter to keep the well casing centered in the borehole.

The well screen materials used for construction of monitoring wells will be composed of new, precleaned, 4-in. stainless steel. Screen sections will be continuous-wound with openings equal to $0.010 \mathrm{in}$. Screen sections will be flush-threaded, and gaskets, pop rivets, and screws will not be used during monitoring well construction. All screens used for monitoring well construction will be installed such that the bottom of each well screen is placed no more than $2 \mathrm{ft}$ above the bottom of the drilled borehole. Each screen section will measure $10 \mathrm{ft}$ in length, and a threaded stainless steel cap or plug will be placed onto the bottom of each screen. The cap/plug will be within 6 in. of the bottom of the well screen.

\subsubsection{Filter pack, bentonite, and grout mixture}

The filter pack size will be appropriately sized for use with the preselected screen slot size. The granular filter pack material will be visually clean (as seen through a 10-power hand lens), free of material that would pass through a No. 200 sieve, inert, siliceous, and composed of rounded grains. The filter material will be packaged in bags or buckets by the supplier and delivered intact to the site.

Granular filter pack material used for monitoring well construction will be placed within the annular space around the monitoring well screen using a tremie pipe. If approved water is used to place the filter pack, the amount of this water will be recorded and added to the volume of water to be removed during well development. The filter pack will extend from the bottom of the borehole to $2 \mathrm{ft}$ above the top of the well screen. The final depth to the top of the filter pack will be measured directly with a weighted tape and recorded on the associated well construction diagram.

Bentonite will be used for one or more of the following purposes:

- creation of an annular seal during monitoring well construction between the granular filter pack and grout seal, and/or

- addition to grout mixture used for creation of grout seal during monitoring well construction.

Compressed, powdered bentonite pellets, generally measuring 0.25 in. in size, will be used for annular seal applications. Powdered bentonite will be used for grout additive applications.

Bentonite seals will be at least $2 \mathrm{ft}$ thick, as measured immediately after placement without allowance for swelling. A tremie pipe will not be used for placement of the pellets unless significant bridging occurs or is suspected of being a problem. Placement of the bentonite will include periodic tamping of the bentonite pellets to prevent bridging during emplacement. After placement of the bentonite pellets, a small volume of approved water will be used, if necessary, to hydrate the pellets, and the 
hydration time for the pellets will be a minimum of $1 \mathrm{~h}$. The final depth to the top of the bentonite seal will be measured directly with a weighted tape and recorded on the associated well construction diagram.

Grout used for monitoring well installation or borehole abandonment will be composed of Type I Portland cement; $3 \mathrm{lb}$ of dry, powdered bentonite per 94-lb sack of dry cement; and a maximum of 7 gal of approved water per sack of cement. All grout materials will be combined in an aboveground, rigid container or mixer and mechanically blended on-site to produce a thick, lump-free mixture throughout the mixing vessel. The grout will be placed using a tremie pipe of rigid construction for vertical control of grout placement. The tremie pipe will be equipped with side discharge holes rather than an open end to help maintain the integrity of the underlying material onto which the grout is placed.

Upon initiation of grouting operations, the process will be conducted continuously until the surface casing is installed or the well is grouted to the required levels. After $24 \mathrm{~h}$, the site will be checked for grout settlement, and more grout will be added at that time to fill any depression. This process will be repeated until firm grout remains at or near the required depth.

\subsubsection{Surface completion}

The well caps used for construction of monitoring wells will be composed of new, precleaned stainless steel. The caps will be fitted to the casings and designed to preclude binding to the casing as a result of tightness of fit, unclean surface, or frost and to allow for equilibration between hydrostatic and atmospheric pressures (i.e., vented). The caps will also be designed to fit securely enough to preclude debris and insects from entering the monitoring well.

Above-grade surface completions will be installed for all monitoring wells. The protective casing used for construction of all monitoring wells will be composed of new carbon steel and equipped with locking covers. The protective casings will be either 6 in. in diameter or 6 in. square. The casing will be of sufficient length to allow $2.5 \mathrm{ft}$ of the casing to extend above the ground surface. The top of each installed monitoring well casing will be level so that the difference in elevation between the highest and lowest points on the top of the well casing is less than or equal to $0.2 \mathrm{in}$.

The guard posts that surround these casings will be at least 3 in. in diameter, and the top of each post will be modified to preclude the entry of water. The guard post length will be $8 \mathrm{ft}$, approximately 3 to $5 \mathrm{ft}$ of which will extend below the ground surface. All of the guard posts will be painted using a paintbrush and will be completely dry before sampling of the well occurs. These protective casings will be surrounded by $3-\mathrm{ft}^{2}, 4$-in.-thick concrete pads sloped away from the casings. Each concrete pad will be surrounded by four new iron/steel guard posts.

\subsubsection{Well development}

Development of the new monitoring wells will not begin until at least $24 \mathrm{~h}$ following completion of the surface pad and protective casing installation. Development will continue until the column of water in the well is free of visible sediment and the field parameters of $\mathrm{pH}$, temperature, turbidity, and specific conductance have stabilized. Well development will be accomplished using pumping/overpumping and surging techniques. 


\subsubsection{Field logs and records}

\section{Boring logs}

All boreholes will be logged in the field by a geologist. Soil samples will be visually classified in accordance with the Unified Soil Classification System. Each borehole log generated for soil sample collection or the installation of monitoring wells will fully describe the subsurface environment and the procedures used to gain that description. Original borehole logs will be of sufficient legibility and contrast so as to provide comparable quality in reproduction and will be recorded directly in the field. below.

All borehole logs generated during the project will routinely contain the following information listed

- Unique borehole number and location denoted on a sketch map as part of the log.

- Depths or heights recorded in feet and decimal fractions thereof (tenths of feet).

- Field estimates of soil classification in accordance with the Annual Book of ASTM Standards, Volume 04.08, D2488 (ASTM 2003) prepared in the field at the time of sampling by the site geologist.

- Full description of each soil/rock sample collected.

- Visual numeric estimates of secondary soil/rock constituents and quantitative definitions of descriptive terms (e.g., trace, some, several) recorded on the log.

- Description of disturbed samples (if used to supplement subsurface description) in terms of the appropriate soil parameters, to the extent practical. At a minimum, classification along with a description of drill action for the corresponding depth. Notations on the log that these descriptions are based on observations of disturbed material rather than intact samples.

- Description of drilling equipment, including such information as auger size (inner and outer diameters), bit types, compressor type, rig manufacturer, and model.

- Sequence of drilling activities.

- Any special problems encountered during drilling and their resolution.

- Dates and times for the start and completion of the borehole, along with notation by depth for drillcrew shifts and individual days.

- Each sequential boundary between various soil types and individual lithologies.

- The depth of first-encountered free water, along with the method of determination.

- Interval by depth for each sample collected, including the length of sampled interval, length of sample recovery, and sampler type and size (diameter and length).

- Total depth of drilling and sampling.

- Results of soil sample organic vapor headspace readings. Notations to include interval sampled, corresponding vapor readings, and key to the specific instrument used to obtain readings. A general 
note on the log indicating the manufacturer, model, serial number, and calibration information for each instrument used.

- Definition of any special abbreviations used at their first occurrence.

\section{Monitoring well construction}

Each monitoring well installed during the project will be depicted in an as-built well construction diagram. Each diagram will be attached to the original borehole log for that installation and will graphically denote, by depth from the ground surface, the following information:

- location of borehole bottom and borehole diameter(s);

- location of well screen;

- location of any joints;

- location of granular filter pack;

- location of bentonite seal;

- location of grout;

- location of centralizers;

- height of riser (stickup), without cap/plug, above the ground surface;

- height of protective casing, without cap/cover, above the ground surface;

- depth of protective casing base below the ground surface;

- location and size of drainage port;

- location of internal mortar collar;

- sloped concrete pad height and diameter;

- protective post configuration; and

- water level $24 \mathrm{~h}$ after completion of installation, with date and time of measurement.

Additional information to be described on each as-built well construction diagram will include the following:

- actual quantity and composition of the grout, bentonite seal, and granular filter pack used for construction of the monitoring well;

- screen slot size in inches, slot configuration, total open area per foot of screen, outside diameter, nominal inside diameter, schedule/thickness, composition, and manufacturer;

- type of material located between the bottom of the borehole and the bottom of the screen;

- outside diameter, nominal inside diameter, schedule/thickness, composition, and manufacturer of the well casing;

- joint design and composition;

- design and composition of centralizers;

- depth and description of any permanent pump or sampling device installed within the monitoring well;

- composition and nominal inside diameter of protective casing;

- any special problems encountered during well construction and their resolution; and 
- dates and times for the start and completion of monitoring well installation, including well development.

Wells installed during the investigation will be numbered consecutively beginning with the next number in the numbering sequence for ETTP bedrock and unconsolidated zone wells.

\subsection{SURFACE WATER AND SEDIMENT SAMPLING}

This section describes the surface water and sediment samples to be collected to address surface water in Zone 1. The surface water data gaps identified for Zone 1 included the absence of chemical and radiological data for surface water and sediment in the Beaver Ponds, located in the K-720 area, and the Oxbow Lake, located north of Poplar Creek and east of the K-1064 Peninsula area. In addition, based on the results of an evaluation of the discharge from Zone 1 storm drain outfalls, the absence of data for PAHs in the K-901-A Pond and the K-1007-P1 Pond was also identified as a data gap. These areas and the proposed data collection are discussed below.

\subsubsection{Beaver Ponds}

The Beaver Ponds, located at the southeast end of the K-720 Slough, were formed as the result of beaver dam-building activities across an existing drainage swale in the area as much as 30 years ago. Over the years the size of the ponds has increased. Beavers continue to be active in the area and the size of the inundated area continues to gradually increase.

The Beaver Ponds consist of two separate ponds bisected by an access road to the K-720 area off of South 1st Street (Fig. 25). The southern pond receives surface water runoff from the surrounding area on the west, and from the east via a culvert beneath South 1st Street near the Highway 58 overpass. The northern pond receives surface water runoff primarily from the west and is reportedly in communication with the southern pond via a culvert beneath the access road. Groundwater discharge also appears to contribute to the ponds and augments the surface water runoff feeding the ponds.

A portion of the runoff and groundwater discharge reaching the northern Beaver Pond originates from the area of the former K-720 Fly Ash Pile. Groundwater in this area has been impacted by leaching of the fly ash through infiltration of precipitation through the soil cover and underlying fly ash material. This leaching has resulted in low $\mathrm{pH}$ groundwater and increased mobilization of metals in the subsurface. Low ph surface water is present in the drainage between the fly ash pile and the K-720 Slough, and in the discharge from the northern pond. The southern Beaver Pond does not receive runoff from the Fly Ash Pile area, and is not expected to be impacted by the discharge of low $\mathrm{pH}$ groundwater.

\section{Data Collection}

In order to determine the potential for impacts to the Beaver Ponds from DOE activities, co-located surface water and sediment samples will be collected from three locations. Two sample locations will be located within the northern Beaver Pond and one sample location will be located within the southern pond (Fig. 26).

Both the surface water samples and the sediment samples will be analyzed for metals, SVOCs, PCBs gross alpha activity, and gross beta activity. These constituents were selected as being the most likely potential contaminants of concern at the Beaver Ponds given the possible impacts due to the leachate generated from the fly ash. 


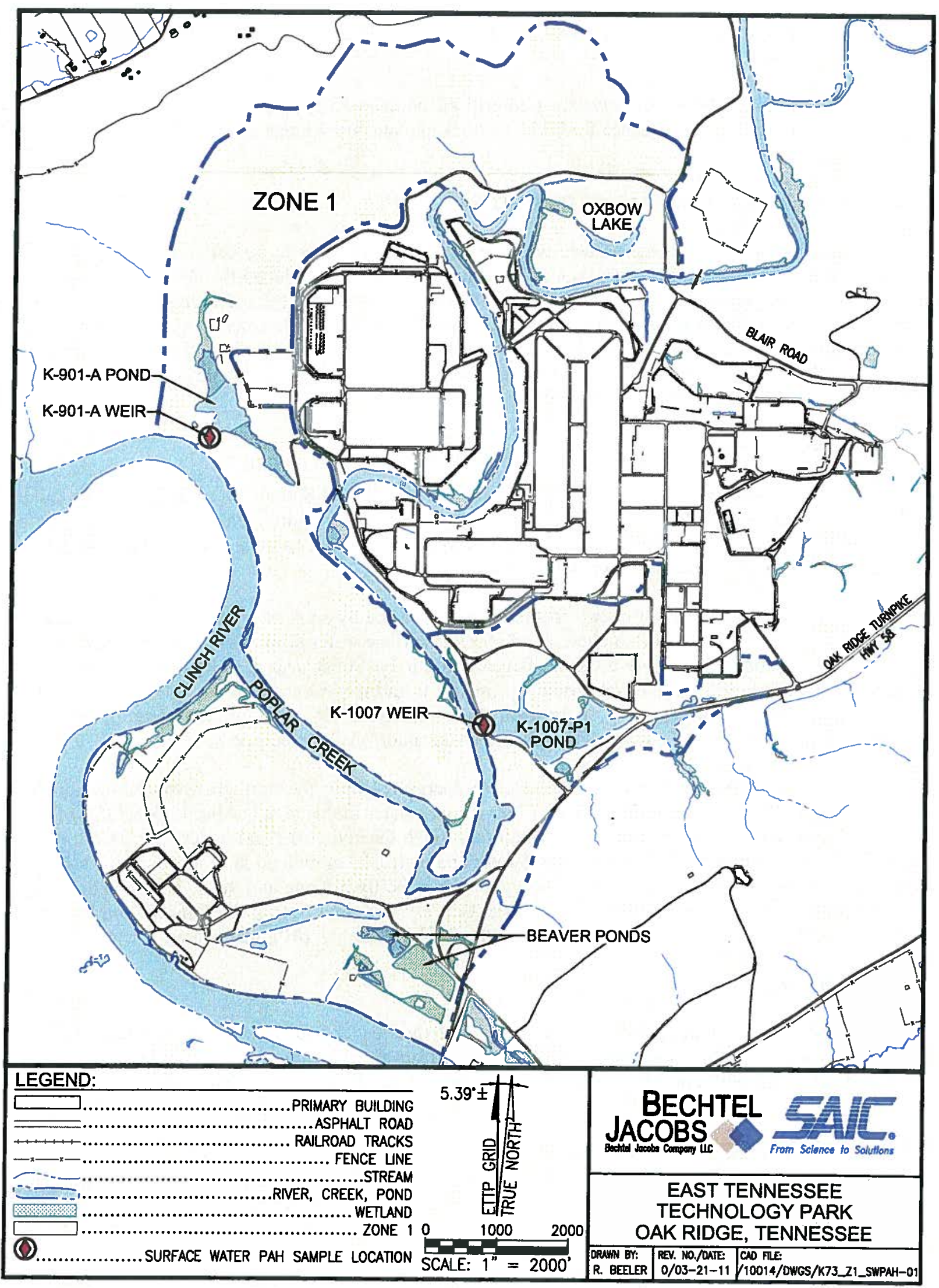

Fig. 25. Surface water bodies in Zone 1 at ETTP. 


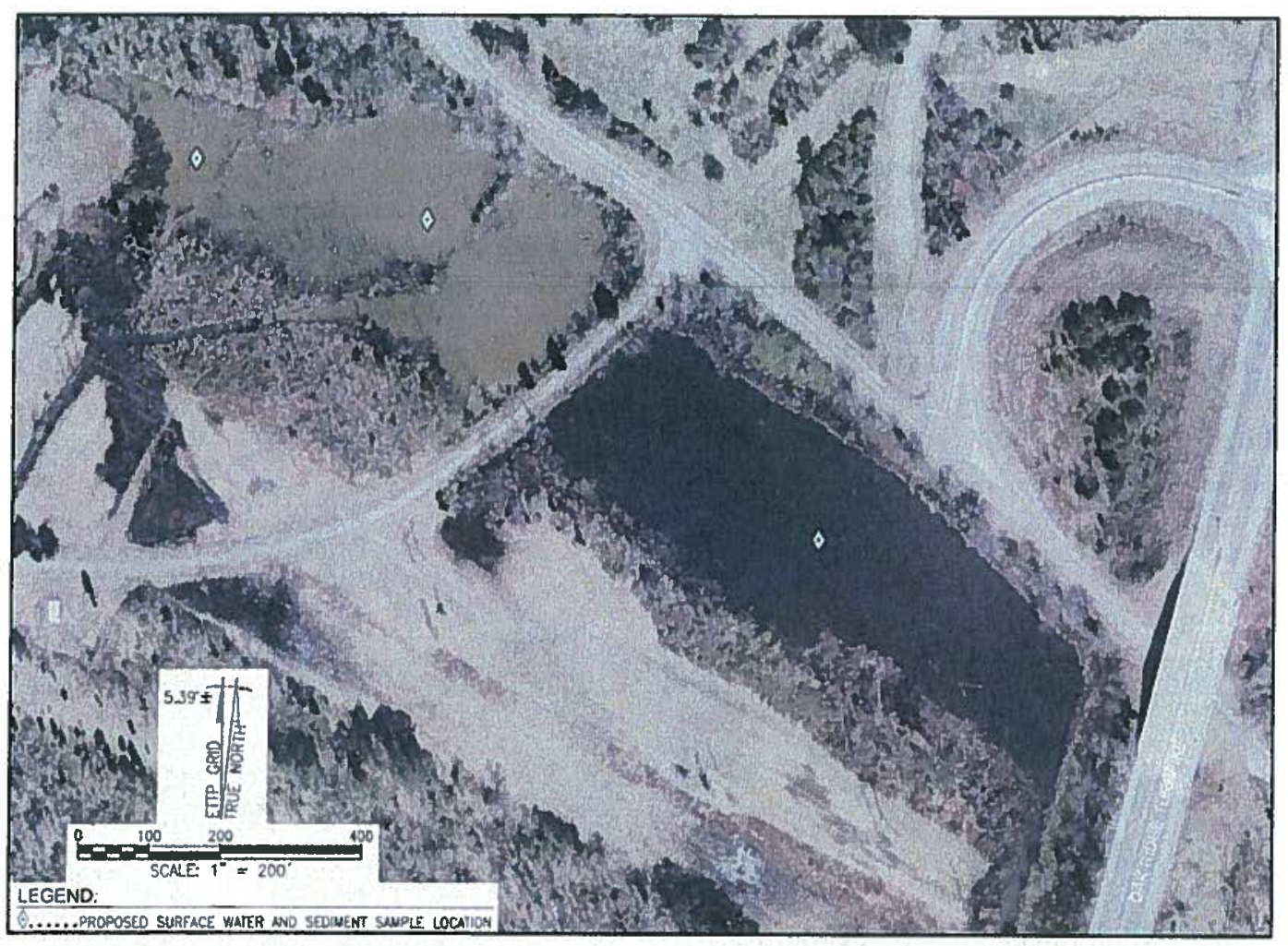

Fig. 26. Proposed sampling locations at the Beaver Ponds.

\subsubsection{Oxbow Lake}

The Oxbow Lake appears to have formed either from a cutoff meander of Poplar Creek or was a former embayment off of Poplar Cree with a drainage paralleling the embayment to the north that flowed to Poplar Creek. Although the crescent-shaped water body has been referred to as the Oxbow Lake, the northern arm of the meander, or former drainage, also is inundated during most of the year and is connected to Poplar Creek via a culvert under the access road. This northern arm of the Oxbow Lake is significantly narrower and less extensive than the southern arm of the Oxbow Lake. The southern arm of the lake is also connected to Poplar Creek by a culvert under the access road. This culvert is raised slightly above the normal pool level of Poplar Creek, which allows communication between the lake and Poplar Creek only during high water stages.

Pre-construction aerial photographs indicate the agricultural activities were conducted in the area of the Oxbow Lake. Aerial photographs from 1959 indicate that adjacent areas to the southwest and to the north of the lake were used as soil borrow areas, and subsequently for what appears to be soil placement. The access road had been constructed and the culvert installed along the west side of the Oxbow Lake by the 1960 s, and the area south of the lake was used as a soil borrow site. Vegetation removal, placement of earthen materials, additional soil mining, site grading, and establishment of the power line corridor in the adjacent areas is evidenced in aerial photographs from the 1970s and 1980s.

Historical records indicate that there have been no site-related activities associated with the Oxbow Lake. The surrounding Zone 1 EUs $(72,73,75$, and 76) have approved NFAs for soil for industrial use to a depth of $10 \mathrm{ft}$. 
In order to determine the potential for impacts to the Oxbow Lake from DOE activities, co-located surface water and sediment samples will be collected from three locations in the southern arm (Fig. 27). One sample location will be located near the east end of the lake, one sample will be located near the midpoint of the lake, and one sample will be located near the west end of the pond to provide general coverage across this water body. The southern arm of the Oxbow Lake is considered to be representative of conditions in both the southern and northern arms of the lake, and any site-related impacts would be evident in the more extensive southern arm.

Both the surface water samples and the sediment samples will be analyzed for metals, SVOCs, PCBs gross alpha activity, and gross beta activity. These constituents were selected as being the most likely potential COCs at the Oxbow Lake based on the activities that were conducted in the surrounding areas.

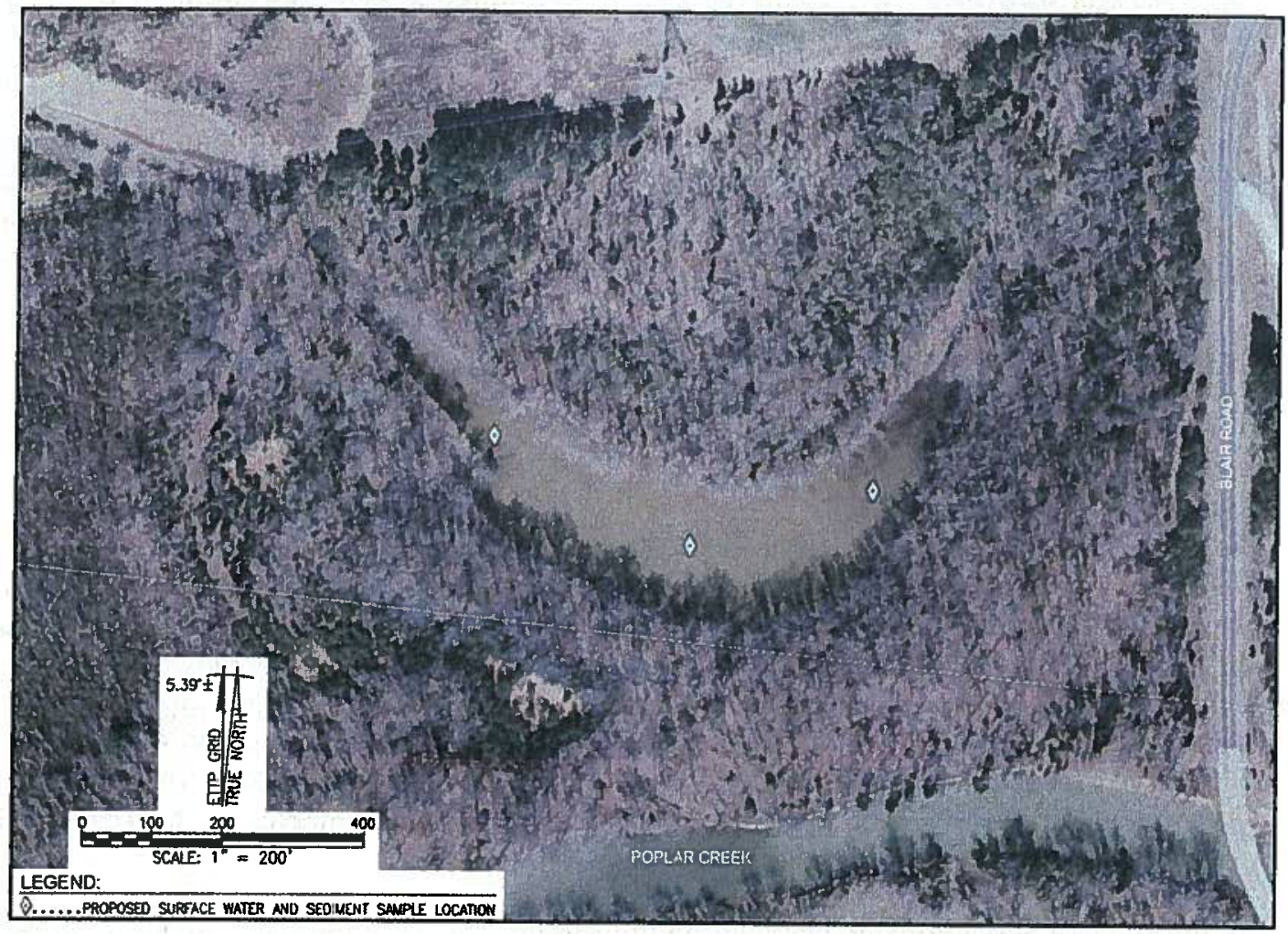

Fig. 27. Proposed sampling locations at the Oxbow Lake.

Surface water samples to be collected from the Beaver Ponds and the Oxbow Lake will be collected from the mid-point of the water column at each designated sampling location using appropriate sample collection techniques. Sediment samples will be collected from the upper $1 \mathrm{ft}$ of sediment using an appropriate grab sampling device. All sampling procedures will be conducted in accordance with EPA Region 4, Science and Ecosystem Support Division (SESD), Field Branches Quality System and Technical Procedures (EPA 2009). 


\subsubsection{K-1007-P1 Pond}

Based on the results of the storm drain evaluation conducted for the Zone 1 storm drain outfalls, it was determined that some samples collected from the storm drains discharging to the K-1007-P1 Pond exceeded state of Tennessee ambient water quality criteria (AWQC) for several metals, one PCB, and two PAHs. The evaluation also included a comparison of the storm drain results to surface water sample results from the pond itself. The results for surface water samples collected from the K-1007-P1 Pond indicated that the metals and the PCB compound are generally not detected at concentrations above the AWQCs in the pond surface water. However, data for PAHs did not exist for comparison to the storm drain results. Thus, it was determined that surface water samples for PAHs would be collected from the K-1007-P1 Pond in order to evaluate the potential impacts of the storm drain results.

\subsubsection{K-901-A Pond}

Similar to the K-1007-P1 Pond, concentrations of two metals and two PAHs exceeded their respective AWQC in the storm drains discharging to the K-901-A Pond. The metals were found to not exceed AWQCs in the K-901-A Pond; however, concentration data for PAHs in surface water in the pond was not available. Thus, in order to evaluate the potential impacts of the storm drain discharges to the K-901-A Pond, it was determined that surface water samples for analysis for PAHs will be collected.

The surface water samples for PAHs will be collected at the K-1007-B weir and the K-901-A Pond weir structures (see Fig. 25) using appropriate surface water sampling techniques.

\section{INVESTIGATION-DERIVED WASTE}

See the East Tennessee Technology Park Site-Wide Residual Contamination Remedial Investigation Work Plan (DOE 2004).

\section{QUALITY CONTROL MEASURES}

See the East Tennessee Technology Park Site-Wide Residual Contamination Remedial Investigation Work Plan (DOE 2004).

\section{PROJECT SCHEDULE}

The work described in this document is planned to start in early March 2011 and end in late May 2011. The work will start at risk prior to approval of this document.

\section{REFERENCES}

DOE 1999. Remedial Investigation Report for the East Tennessee Technology Park, Oak Ridge, Tennessee, DOE/OR/01-1778/V1\&D1, Office of Environmental Management, Oak Ridge, TN. 
DOE 2002. Removal Action Report for the K-1085 Old Firehouse Burn Area Drum Burial Site, East Tennessee Technology Park, Oak Ridge, Tennessee, DOE/OR/01-2050\&D1, U. S. Department of Energy, Office of Environmental Management, Oak Ridge, TN, December.

DOE 2004. East Tennessee Technology Park Site-Wide Residual Contamination Remedial Investigation Work Plan, Oak Ridge, Tennessee, DOE/OR/01-2154\&D2, U. S. Department of Energy, Office of Environmental Management, Oak Ridge, TN.

DOE 2006a. Phased Construction Completion Report for the K-1007 Ponds Area and Powerhouse Area in Zone 1 at East Tennessee Technology Park, Oak Ridge, Tennessee, DOE/OR/01-2294\&D2, U. S. Department of Energy, Office of Environmental Management, Oak Ridge, TN, August.

DOE 2006b. Phased Construction Completion Report for the Duct Island Area and K-901 Area in Zone 1, East Tennessee Technology Park, Oak Ridge, Tennessee, DOE/OR/O1-2261\&D2, U. S. Department of Energy, Office of Environmental Management, Oak Ridge, TN, February.

DOE 2007a. Final Sitewide Remedial Investigation and Feasibility Study for East Tennessee Technology Park, Oak Ridge, Tennessee, DOE/OR/01-2279\&D3, U. S. Department of Energy, Office of Environmental Management, Oak Ridge, TN, November.

DOE 2007b. Phased Construction Completion Report for the K-770 Scrap Removal Project of the Zone 1 Remediation at the East Tennessee Technology Park, Oak Ridge, Tennessee, DOE/OR/O12348\&D1, U. S. Department of Energy, Office of Environmental Management, Oak Ridge, TN, April.

DOE 2009. Addendum to the Phased Construction Completion Report for the Duct Island Area and K-901 Area in Zone 1, East Tennessee Technology Park, Oak Ridge, Tennessee, DOE/OR/012261\&D2/A1, U. S. Department of Energy, Office of Environmental Management, Oak Ridge, TN, December.

DOE 2010. Addendum to the Phased Construction Completion Report for the K-1007 Ponds Area and Powerhouse North Area in Zone 1, East Tennessee Technology Park, Oak Ridge, Tennessee, DOE/OR/01-2294\&D2/A1, U. S. Department of Energy, Office of Environmental Management, Oak Ridge, TN, June.

Energy Systems (Lockheed Martin Energy Systems, Inc.) 1995. Site Descriptions of Environmental Restoration Units at the Oak Ridge K-25 Site, Oak Ridge, Tennessee, K/ER-47/R1, K-25 Site, Oak Ridge, TN.

EPA (U.S. Environmental Protection Agency) 2009. Field Branches Quality System and Technical Procedures, Region 4, Science and Ecosystem Support Division, Athens, GA, available at http://www.epa.gov/Region4/sesd/fbqstp/index.html.

EPA 2010. Test Methods for Evaluating Solid Waste, Physical/Chemical Methods, SW-846 On-Line, http://www.epa.gov/wastes/hazard/testmethods/sw846/online/index.htm. 
APPENDIX A

\section{QUALITY ASSURANCE PROJECT PLAN}


Table A.1. Analytical data measurement quality objectives, ETTP site-wide RI work plan, Oak Ridge, Tennessee

\begin{tabular}{|c|c|c|c|c|c|c|c|c|}
\hline \multirow{3}{*}{ Media } & \multirow{3}{*}{ Analysis } & \multirow{3}{*}{ Analytical method } & \multicolumn{4}{|c|}{ Precision } & \multirow{3}{*}{$\begin{array}{l}\text { Accuracy LCS } \\
\text { (\% recovery) }\end{array}$} & \multirow[b]{3}{*}{ Completeness } \\
\hline & & & \multicolumn{2}{|c|}{ Field duplicates (RPD) } & \multicolumn{2}{|c|}{ Lab duplicates (RPD) } & & \\
\hline & & & Fish/solid & Aqueous & Fish/solid & Aqueous & & \\
\hline $\begin{array}{l}\text { Groundwater } \\
\text { and surface } \\
\text { water. }\end{array}$ & Metals & $\begin{array}{l}\text { SW-846 }{ }^{a} \text { Method } 6010 \mathrm{~B}, 6020 \text {, or } 7000 \\
\text { series, or EPA Method } 1631, \text { Rev E }\end{array}$ & $<50$ & $<30$ & $<50$ & $<20$ & $80-120 \%$ & $95 \%$ \\
\hline
\end{tabular}

${ }^{a}$ Test Methods for Evaluating Solid Waste, SW-846, 3rd ed. (EPA 2010).

$\mathrm{CLP}=$ Contract Laboratory Program.

EPA $=$ U. S. Environmental Protection Agency.

ETTP $=$ East Tennessee Technology Park

LCS = laboratory control sample.

$R I=$ remedial investigation

$\mathrm{RPD}=$ relative percent difference. 
Table A.6. Project reporting levels for metals in water and sediment, ETTP site-wide RI work plan, Oak Ridge, Tennessee

\begin{tabular}{|l|c|c|c|c|c|c|}
\hline & & \multicolumn{2}{|c|}{ Water $(\mu \mathrm{g} / \mathrm{L})$} & \multicolumn{3}{c|}{ Sediment $(\mathrm{mg} / \mathrm{kg})$} \\
\cline { 2 - 7 } Compound & CAS \# & $\begin{array}{c}\text { Method } \\
\text { Reporting } \\
\text { Level }\end{array}$ & $\begin{array}{c}\text { National Primary } \\
\text { Drinking Water } \\
\text { Standard }\end{array}$ & $\begin{array}{c}\text { Method } \\
\text { Reporting } \\
\text { Level }\end{array}$ & $\begin{array}{c}\text { Human } \\
\text { Health } \\
\text { Screening } \\
\text { Level }^{c}\end{array}$ & $\begin{array}{c}\text { Ecological } \\
\text { Screening } \\
\text { Level }\end{array}$ \\
\hline Mercury & $7439-97-6$ & $0.05^{a}$ & $2^{b}$ & 0.1 & 5.6 & $0.18^{d}$ \\
\hline
\end{tabular}

${ }^{a}$ Method 1631, Rev E.

${ }^{b}$ Standard is for inorganic. 2010.

U. S. Environmental Protection Agency (EPA) Regional Screening Level, residential soil, November

${ }^{d}$ EPA Region 3 Ecological Sediment Screening Benchmark (EPA 2006)

CAS $=$ Chemical Abstracts Service.

ETTP $=$ East Tennessee Technology Park.

$\mathrm{RI}=$ remedial investigation. 
DOE/OR/01-2154\&D2/A1

\section{RECORD COPY DISTRIBUTION}

File-EMEF DMC-RC 